NBER WORKING PAPER SERIES

\title{
DOES SECULAR EDUCATION IMPACT RELIGIOSITY, ELECTORAL PARTICIPATION AND THE PROPENSITY TO VOTE FOR ISLAMIC PARTIES? EVIDENCE FROM AN EDUCATION REFORM IN A MUSLIM COUNTRY
}

\author{
Resul Cesur \\ Naci H. Mocan \\ Working Paper 19769 \\ http://www.nber.org/papers/w19769 \\ NATIONAL BUREAU OF ECONOMIC RESEARCH \\ 1050 Massachusetts Avenue \\ Cambridge, MA 02138 \\ December 2013
}

\begin{abstract}
We are grateful to Bekir Ağırdır for providing us with the data and to Eren Pultar, and Aydın Erdem for generously sharing their expertise of the survey. We thank Luiza Pogorelova and Bahadır Dursun for excellent research assistance, and Dani Rodrik, Michael Grossman, Leyla Mocan, Alper Dinçer, Sezgin Polat, Ayça Akarçay Gürbüz, Etienne Lehmann, Nurhan Davutyan, Claudine Desrieux, Barış Kaymak, Damba Lkhagvasuren, Duha Altındağ and seminar participants at ERMES-Universite de Paris II, Kadir Has University, Concordia University and LSU for helpful comments. The views expressed herein are those of the authors and do not necessarily reflect the views of the National Bureau of Economic Research.
\end{abstract}

NBER working papers are circulated for discussion and comment purposes. They have not been peerreviewed or been subject to the review by the NBER Board of Directors that accompanies official NBER publications.

(C) 2013 by Resul Cesur and Naci H. Mocan. All rights reserved. Short sections of text, not to exceed two paragraphs, may be quoted without explicit permission provided that full credit, including $₫$ notice, is given to the source. 
Does Secular Education Impact Religiosity, Electoral Participation and the Propensity to Vote for Islamic Parties? Evidence from an Education Reform in a Muslim Country

Resul Cesur and Naci H. Mocan

NBER Working Paper No. 19769

December 2013

JEL No. I21,I28,K4,Z1,Z12,Z18

\begin{abstract}
Turkey, which is a predominantly Muslim country, enacted an education law in 1997 which increased the compulsory secular education from five to eight years. We employ a unique nation-wide survey of adults in 2012 to investigate the impact of education on religiosity, lifestyles and political preferences by using exposure to the law as an instrument for schooling. The data set includes information about the extent of religiosity, lifestyle choices (e.g. modern, conservative, religious), ethnic background (e.g. Kurd, Turk, Arab) and the religious sect of the respondents (Sunni, Alevite Shii'te, etc.) The results show that the reform had a significant impact on middle school completion for both men and women, with stronger effects on women. An increase in education, generated by exposure to the law, decreases women's propensity to identify themselves as religious. Education also lowers women's tendency to wear a religious head cover (head scarf, religious turban or burka) and it increases their propensity to have a modern lifestyle. Education reduces women's propensity to cast a vote for Islamic parties, but it has no impact on the propensity to vote. Education has no statistically significant impact on men's religiosity or their tendency to vote for Islamic parties. The results are robust to controlling for indicators of individuals' economic well-being as well as variations in empirical specification of the treatment by the law. Using a smaller version of the survey, conducted in 2008, we perform a variety of tests, which demonstrate that the results are not due to a cohort effect. Finally, we show that the effect of education on religiosity and voting preference is not working through migration, residential location or labor force participation.
\end{abstract}

\author{
Resul Cesur \\ Finance Department \\ University of Connecticut \\ 2100 Hillside Road Unit 1041 \\ Storrs, CT 06269-1041 \\ and University of Connecticut \\ cesur@business.uconn.edu \\ Naci H. Mocan \\ Department of Economics \\ Louisiana State University \\ 3039 BEC \\ Baton Rouge, LA 70803-6306 \\ and NBER \\ mocan@1su.edu
}




\section{Does Secular Education Impact Religiosity, Electoral Participation and the Propensity to Vote for Islamic Parties? Evidence from an Education Reform in a Muslim Country}

\section{Introduction}

Education has a causal impact on productivity in the labor market as well as productivity outside the labor market. For example, education increases wages (Oreopoulos 2006, Card 2001), and the more educated are healthier (Grossman 1972, Grossman 2008, Cutler and LlerasMuney, 2010, Mocan and Altindag 2013). Education can also change individuals' behaviors by altering their time discounting (Becker and Mulligan 1997) and it can change their preferences in a variety of dimensions ranging from fertility to tolerance for violence (Cannonier and Mocan 2012, Lavy and Zablotsky 2011, Osili and Long 2008).

A particularly important impact of education on individual beliefs and preferences involves religion. Philosophers and social scientists, ranging from Durkheim to John Stuart Mill, from Karl Marx to Max Weber have long argued that increased levels of education would generate a decline in religiosity. Specifically, it has been hypothesized that as countries develop economically and as the levels of education rise, the need for religious adherence would diminish. Empirical evidence on the issue, however, is mixed. Using the World Values Survey data over 80 countries ranging 1981 to 2001 as well as other data sets spanning longer periods, Norris and Inglehart (2004) describe the evolution of religious participation, religious values and beliefs by country. They present evidence that while advanced industrial societies have generally trended away from religiosity, the same is not true for developing countries.

Isolating the impact of education on religiosity is complicated. Analyses of country-level data reveal correlations between education and the extent of religiosity (McClearry and Barro $2006 \mathrm{a}, \mathrm{b})$ but they are not useful in determining causality from education to religiosity. Glaeser 
and Sacerdote (2008) use individual-level data from the General Social Survey of the U.S. and find that church attendance is positively related to education at the individual level but that the relationship between the two variables is negative at the aggregate level. ${ }^{1}$ The survey of Iannacone (1998) reports that religious activity tends to rise, rather than decline, with education. Deaton (2011), on the other hand, finds a negative relationship between individual education and religiosity using the Gallup World Poll data. No causal interpretation is possible in these studies either because individual-level data suffer from the same problem as aggregate data. Specifically, it is difficult to make a cause-and-effect interpretation without making use of some exogenous variation in individuals' education that is uncorrelated with their religious beliefs.

In this paper, we exploit the impact of a law enacted in Turkey in 1997 that increased the mandatory years of schooling from 5 to 8 years. The law, which was passed very quickly and rather unexpectedly, generated an exogenous increase in education of the cohorts of children who were younger than 11 years of age in 1997 but it had no impact on those who were older. We employ a unique data set, obtained from the KONDA Research and Consultancy—one of the most prominent research and consultancy firms in Turkey, of a large nation-wide survey about voting behavior, religious beliefs and practices in $2012 .^{2}$ As we explain in the data section, the KONDA Research and Consultancy has an outstanding record of predicting the outcomes of recent Turkish elections using these same data, which minimizes any concerns about the reliability of the information provided by the respondents.

\footnotetext{
${ }^{1}$ They present a model in which education has two distinct effects on religious attendance. Education has a direct negative effect on religious beliefs and religious activity, but secondarily education increases the returns from social connections and networks and that church attendance gives people networking opportunities although attendance per se is not related to religiosity.

${ }^{2}$ Founded in 1986, KONDA Research and Consultancy is one of the leading public opinion survey companies in Turkey.http://www.konda.com.tr/en/about us.php
} 
The data contain detailed information on individuals, some of which are not available in any other data sets including the religious sect of the person (Sunni, Alevite Shiite, etc.), as well as his/her ethnic identity (Turk, Kurd, Arab, and so on). We investigate the extent to which being exposed to three additional years of education due to the law has impacted religious beliefs and practices, such as whether individuals consider themselves an atheist, a "believer", a religious Muslim, or a devout Muslim; and whether women wear head cover (a headscarf, a religious "turban") or completely cover themselves with a burka -all strong indications of religiosity. We also analyze the extent to which people describe their lifestyle as modern, as opposed to traditional conservative or religious conservative.

The impact of education on religiosity has implications for the political economy of development because there is significant and growing influence of religion on politics in a number of countries around the world (Micklethwait and Wooldridge 2009). This has been especially the case for Muslim countries in the Middle East and North Africa during the last decade. Typical features of these countries are low income per capita, an immature democracy, low levels of education, and high religiosity. ${ }^{3}$ Furthermore, this region has been experiencing a surge in Islam-inspired politics during the last decade. If education has a causal impact on religiosity, an increase in the level of secular education could have an impact on the political landscape of these countries.

We have information in the data about the specific political party the person voted for in the 2011 general election in Turkey as well as how he/she would to vote if elections were held today. We investigate whether an increase in education, produced by the reform, alters the

3 The northern part of this region consists of Morocco, Tunisia, Libya, Egypt, Jordan, Iraq, Syria, Iran, Algeria, Turkey, Israel and Cyprus. In all of these countries, with the exception of the last two, Islam is the dominant religion. Table A1 in the appendix presents income per capita, education, a measure of religiosity and an index of democracy in these countries. 
propensity to vote for an Islamic political party. ${ }^{4}$ Because Turkey was governed by an Islamic party in 2012, an individuals' propensity to vote against an Islamic party could in part be a reflection of his/her dissatisfaction with economic and social policies. For example, because younger individuals have higher joblessness rates they may be more concerned about their economic future. ${ }^{5}$ Younger individuals generally have more education as they were exposed to the education reform, but the propensity to vote against the governing Islamic party may be driven by the concern of joblessness, rather than by education. To account for this potential confounding, we also estimate models by adding two variables that measure whether the individual faces economic difficulty currently, and the extent to which he/she expects difficult economic times in the months ahead. This exercise does not alter the estimated impact of education on religiosity, modernity or voting behavior.

Education is also expected to provide social externalities by improving individuals' propensity for civic participation. ${ }^{6}$ While empirical evidence generally indicates that education increases the propensity to vote (e.g. Dee 2004, Milligan, Moretti, Oreopoulos 2004), the research on voter turnout and civic participation has focused on developed countries (Degan and

\footnotetext{
${ }^{4}$ A brief history of Islamic political movement in Turkey and the concept of Islamic political parties are provided in the appendix.

${ }^{5}$ In Turkey the unemployment rate of men ages $15-24$ was $17 \%$ in 2011 , while the rate was $9 \%$ for men ages 25-34. Women ages 15-24 faced an unemployment rate of $21 \%$ in 2011 , while the unemployment rate of women ages 25-34 was 13\%. On the other hand, Mocan L. (2013) finds that the same education reform had a significant impact on wages conditional on employment, especially for women.

6 Theoretical reasons for this impact of education include an increase in cognitive ability that would reduce the cost of civic participation (Wolfinger and Rosenstone 1980), and an increase in subjective benefits of civic engagement by altering preferences in favor of democratic values (see Dee 2004 for a detailed discussion). Along similar lines, Campante and Chor (2012a,b) underline the interplay between schooling, economic conditions and political participation. More generally, Botero, Ponce and Shleifer (2012) argue and present evidence that better educated people are more likely to engage in monitoring the functioning of the government and that they are more likely to complain about the misconduct by government officials.
} 
Merlo 2011, Siedler 2010, Di Pietro and Delprato 2009). ${ }^{7}$ Because our data contain information about whether the respondent went to the ballot box and casted a vote during the last election and whether he/she intends to do so if an election were held today, we analyze whether an increase in education leads to a greater tendency to vote.

Two recent papers investigate the impact compulsory schooling laws on religiosity. Hungerman (2011) uses data from Canadian censuses and run regressions where the unit of observation is the fraction of people in each province and year with no religious affiliation. $\mathrm{He}$ finds that increases in the province-level mandatory years of education (enacted mostly in the 1950s and 1960s) had a positive impact on the proportion of people with no religious affiliation in the 1971-2001 census years. Gulesci and Meyersson (2013) examine the effect of the same education reform we analyze. They use a sample of about 1,800 observations from Turkish Demographic Health Survey and find that in case of women the education reform lowered some indicators of religiosity such as wearing a head scarf and studying the Qur'an, but the reform had no significant impact on other important indicators of religiosity such as praying five times a day and fasting during Ramadan. ${ }^{8}$ The authors find somewhat more consistent results in the analysis of the marriage attributes of women, where those women who were exposed to the reform are more likely to make their own marriage decisions and their own fertility decisions, but there is no impact of the reform on labor market outcomes. The lack of the impact on most outcomes could be because of the relatively small sample size the authors had to employ, although the

\footnotetext{
${ }^{7}$ Studies providing descriptive accounts of the relationship between education and civic participation in developing counties report conflicting findings on the association between the two variables (Pande 2011).

${ }^{8}$ Praying five times a day and fasting during the month of Ramadan are two of the five requirements of Islam, by which each religious Muslim must abide.
} 
point estimates of the coefficient of schooling in some of these regressions, such as praying, fasting as well as labor market outcomes are very small (Gulesci and Meyersson 2013). ${ }^{9}$

We use exposure to the mandate of the reform as an instrument for education and find that education has a significant impact on religiosity of women. Specifically, having a middle school diploma, as opposed to having an elementary school degree due to the exposure to the reform, reduces women's propensity for self-identifying themselves as being religious by about 30 percentage points, and it increases the propensity to have a modern lifestyle by the same magnitude. Three additional years of education, associated with a middle school diploma, reduces the propensity to wear a head cover such a head scarf, a religious turban, or a burka by about 40 percentage points. Although middle school education does not impact women's propensity to vote in elections, it reduces the propensity to cast a vote for an Islamic party by about 50 percentage points. An increase in education does not have a statistically significant impact on religiosity or voting behavior of Muslim men.

The effect we estimate is the total impact of secular education on religiosity and on the propensity to vote for Islamic parties. The impact of education can work through a number of channels. For example, education is expected to increase the cognitive ability of people, which in turn can influence people's beliefs. In addition, being required to attain three additional years of schooling during adolescence may increase sociability, social networks and exposure to a variety of experiences, all of which may alter preferences. Increased education could also motivate individuals to move from rural areas to cities, and residing in a city may change people's preferences in a number of dimensions, including religion. Furthermore, education may

\footnotetext{
${ }^{9}$ The small sample size is also the likely reason for these authors not to detect an impact of the education reform on years of schooling for men. In our sample, which is larger, we find that the reform had a positive impact on male educational attainment. Mocan L. (2013) who uses a large national sample from Turkish Statistical Institute, also reports that male educational attainment is significantly impacted by the reform.
} 
increase the propensity to participate in the labor force, which may also alter religiosity. In Section $\mathrm{V}$ of the paper we present evidence which demonstrates that migration, residential location or labor force participation are not likely channels through which education impacts the outcomes analyzed in the paper.

Regressions control for linear and quadratic age variables. Nevertheless, concerns might be raised about the possibility that the results could have been confounded because younger individuals are exposed to the education reform while older ones are not, and some unobserved correlate of age might be the primary reason for the impact on religiosity and support for Islamic parties. To address this concern, we use a supplementary survey from the year 2008. This survey, which is similar to the main survey used in the paper, is conducted by the same company and it includes questions on modernity and wearing a head cover. By using both the 2012 and the 2008 surveys we perform analyses which demonstrate that the impact of education identified in the paper is not due to a cohort effect. We also estimate a difference-in-differences specification, the results of which support the findings of the paper. These specifications are discussed in Section V.

Section II describes the education reform that has increased the mandatory years of schooling in Turkey, and introduces the data set. Section III introduces the data and the variables, Section IV presents empirical methodology and the results; Section V includes the robustness analyses and Section VI is the conclusion. In the appendix we provide detailed background information on the history of Islamic parties and the headscarf debate in Turkey. 


\section{The 1997 Education Reform}

On August 18, 1997, the secular Turkish government increased compulsory schooling from 5 to 8 years (Law no: 4306). ${ }^{10}$ Commonly known in Turkey as the "The Reform for Uninterrupted 8-years of Education" the new law went into effect immediately in the beginning of the 1997-98 education year, in the Fall of 1997 (K1rdar et al. 2011, 2012). Students who had completed the fourth grade or lower at the end of the 1996-97 education year in Spring 1997 had to comply with the new law (Kirdar et al. 2011, 2012), while students who had finished the fifth grade in the spring of 1997 were exempt from it.

In Turkey students may enroll in the first grade once they are six years old. The interpretation of this restriction has been for the child to be at least 72 months old when the school year starts in September. This means that a child born in September 1986 would be 73 months old in September 1992 and would start the first grade, but children born in OctoberDecember 1986 would miss the age cut-off to start the school in September 1992. The law, however, states that a child may start the first grade if he/she is 72 months old at the end of the

calendar year. ${ }^{11}$ It is also known that the age cut-off is not strictly enforced and that children are allowed to start school if they are on the margin of the 72-month cut-off. Thus, those who are born at the end of 1986 (in October-December) could have started school in 1992. By the same token, those who are born in early 1986 would start the first grade in Fall 1991, rather than Fall 1992.

The upshot is that although most of the children of the 1986 cohort would have enrolled in the first grade in 1992 and therefore have completed the fifth grade in Summer 1997 and thus

\footnotetext{
${ }^{10} \mathrm{http}: / /$ mevzuat.meb.gov.tr/html/126.html

${ }^{11}$ Resmi Gazete; Friday, 7 August 1992, Section 14.
} 
were exempt from the mandate of the education reform, some children who were born in 1986 have completed only the fourth grade and these children were impacted by the reform.

During the time period when the law was enacted Turkey was involved in heavy negotiations for the European Union membership and the government was concerned that European Union negotiations would not proceed without the implementation of a reform that increased the level of education in Turkey (Dulger 2004). The law was also an attempt to limit the extent of religious education. We elaborate on this issue and the political landscape in Turkey in 1997 in the next sub-section. Prior to the education reform, mandatory education was limited to five years in Turkey and after completing five years of primary schooling, students had three options: (i) discontinue their education, (ii) go on to secondary schooling (for an additional three years) at traditional middle schools; (iii) go on to secondary schooling at vocational schools, including the religious schools which are in part designed to educate religious clerics to be employed by religious enterprises including the mosques. ${ }^{12,13}$ The education reform of 1997 did not involve any changes in curriculum; that is neither the course contents nor the composition of courses are effected by the reform (Dulger 2004). But, the reform combined the primary and middle schools. Therefore, stand-alone middle schools, including vocational middle schools, were closed. Vocational high schools, including religious ones, could only admit students after the students have completed their 8-year of mandatory schooling.

The reform had a strong effect on educational attainment. Previous research has shown that among those who were affected by the law, the probability of completing middle school and years of schooling significantly increased (Mocan L. 2013, Kirdar et al. 2011, 2012). We confirm this result in our data. Excluding books, supplies, school uniforms and commuting

${ }^{12}$ Girls can also attend these religious vocational schools, although they are not allowed to be clerics upon graduation by the rules of Islam.

${ }^{13} \mathrm{http}: / /$ www.studyinturkey.com/content/sub/education_system.aspx 
costs, compulsory education is free and non-compliance is subject to monetary fines in Turkey. ${ }^{14}$ However, even though the original 5-year mandatory education law, as well as the new law require financial penalties for the families that do not send their children to school and for families of the students who drop out prior to the completion of compulsory schooling, the fine has not been strictly imposed. ${ }^{15}$ Therefore, while the middle school graduation rates increased above 90 percent after the reform, perfect compliance could not be achieved (Kirdar et al. 2012).

\section{Political Backdrop when the Law was Passed}

The law was passed in August 1997 by the $55^{\text {th }}$ government of Turkey, led by the Prime Minister Mesut Yilmaz. This was a coalition government made up by three political parties with secular traditions. ${ }^{16}$ The immediately preceding government was a coalition between the Welfare Party (Refah Partisi) which has Islamic roots and center-right True Path Party (Dogru Yol Partisi). Because the Welfare Party had more seats in the Parliament than the True Path Party, its leader Necmettin Erbakan was the Prime Minister of this government. This $54^{\text {th }}$ government of Turkey was formed in June 1996 and it was the first government of the country led by an Islamic Party. A number of events during the fall of 1996 and winter of 1997 , however, raised concerns about intrusion of religion into the government, and prompted reactions from both the military and the secular segments of the society. On February 28, 1997 the National Security Council of Turkey declared a manifesto and recommended a list of actions to curb the rise of political Islam in Turkey. In May 1997 the Chief Constitutional Prosecutor of the country filed a law suit against the governing Welfare Party, charging it with actions that

\footnotetext{
${ }^{14}$ http://mevzuat.meb.gov.tr/html/24.html

$15 \mathrm{http}: / /$ spm.ku.edu.tr/wp-content/uploads/pdf/okulterk.pdf

16 Two center-right parties: The Motherland Party (ANAP) and The Democratic Party of Turkey (DTP) and the center-left Democratic Left Party (DSP).
} 
undermine the secular foundations of the nation. Under this pressure, on June 18, 1997 after having served one year as Prime Minister, Erbakan resigned to allow the leader of the coalition party, Tansu Ciller, to take over as Prime Minister instead. After this resignation, however, the demands of the secular segments of the society as well as the pressure from the military led the President of the country to task a different political party to form a new government.

Consequently, a new coalition government was formed between three secular parties and the leader of one of these parties, Mesut Yilmaz, became the Prime Minister and the head of the $55^{\text {th }}$ government on June 30, 1997; and his government passed the education reform in August 1997 and implemented in Fall 1997.

The sequence of these events is potentially important, because the Welfare Party, which in 1996 became the first government with Islamic roots in Turkey, had received 21 percent of the popular vote in the general elections one year earlier. ${ }^{17}$ The fact that this Islamic party was forced to step down during the summer of 1997, and a secular education reform was passed a few months later by a different government could have influenced the sensitivity of the supporters of the Welfare Party. Specifically, even though the law mandated three additional years of education beyond the fifth grade, a religious conservative family could have provided religious education to their children on the weekends or after school to counteract and neutralize the influence of the additional years of secular education imposed on their children. The same is true for a family that may have been planning to enroll their child at a religious school before the enactment of the law, but was forced to keep the child three additional years in school after the law. If such families and children are prevalent, it would be more difficult to detect an impact of the reform on religiosity. This is because although such students are exposed to the law and their

\footnotetext{
${ }^{17}$ Although the predecessor of this Islamic Party participated in governments as a coalition partner in the 1970s, 1996 is the first year the party became the lead-party of the government and held the post of Prime Minister.
} 
education is increased, the impact of education on increasing scientific and critical thinking skills and reducing the tendency to believe in supernatural forces may have been mitigated by enhanced religious education provided at home. If this conjecture is true and if it is widespread, the estimated impact of the reform on religiosity would be biased towards zero. It should be noted, however, that the share of students enrolled at religious middle and high schools among all students in the relevant age group was only about nine percent in the 1990s, until the reform year of 1997 (Cakir, Bozan and Talu, 2004).

The flipside to this argument is the following possibility. Consider the families whose children just missed the reform's cutoff and therefore were not required to enroll in middle school. Some of these families might decide to send their children to middle school after the reform anyway, although they had no such intensions before the reform. This could be because these parents might recognize that some of their children's friends, who are only one or two years younger, will end up with more education due to the reform and their kids might have a comparative disadvantage in the labor market down the road. We show in the paper that this was not a prevalent phenomenon to be detected in the data.

\section{Data}

We use a unique data set, drawn from the KONDA Barometer, collected by the KONDA Research and Consultancy, which is a prominent research and consultancy firm in Istanbul, Turkey. The KONDA Barometer surveys were conducted nation-wide 11 times a year-during the last weekend of each month except for the month of Ramadan (the month of fasting for Muslims, the timing of which is determined by lunar calendar). Standard election poll questions 
as well as lifestyle questions, including religious beliefs and attitudes are asked on each survey. ${ }^{18}$ Because of their aim to accurately predict the election results and to provide information on public opinion on a number of timely social and political issues, the KONDA Barometer surveys are specifically designed to produce a nationally representative sample. The data we use in the empirical analyses consist of about 9,600 voting-age adults surveyed in 2012 . The reliability of KONDA surveys were confirmed on many occasions as they closely predicted a number of election results including the past two general elections in Turkey, which took place in 2007 and 2011. Hence, the KONDA surveys are well respected both in the Turkish ${ }^{19}$ and international ${ }^{20}$ media (The Economist 2007, The Economist 2008, Reuters 2011). These election predictions are based on the same data used in this paper. The monthly surveys, upon which the data are based, are not conducted on behalf of a particular political party or organization, nor are they sold to such organizations. Instead, these data are used to conduct independent political analyses as well as to predict political trends and election outcomes.

The data we use were collected in 2012. The analysis sample consists of respondents who were born between 1980 and 1994; that is, they were between the ages of 18 and 32 in 2012. Turkey is a country in which 98 percent of the population is Muslim. This is also

\footnotetext{
${ }^{18}$ In addition, each month's survey is organized around a unique socio-political theme each month. Detailed information on 2012 KONDA Barometer themes can be found at the following link: http://www.konda.com.tr/en/raporlar/KONDA Barometer 2012 Brochure.pdf.

${ }^{19} \mathrm{http} / /$ www.sabah.com.tr/Gundem/2011/06/13/secimi-hangi-anket-sirketi-bildi http://www.konda.com.tr/konda images/tr/ulusal_basin/2011_06_KONDA_Gazetelerin_Tanikligiyla_K ONDA Olcumleri.pdf http://www.blogmilliyet.com/19-temmuz-persembe/Blog/?BlogNo=53053

${ }^{20}$ Note: in some of the below articles, Tarhan Erdem, the founder of KONDA, is mentioned. http://www.economist.com/node/9558347?story id=E1 JVVRPQS http://www.economist.com/node/11745570?story id=E1 TTSQVVSD http://www.reuters.com/article/2010/09/11/us-turkey-referendum-pollidUSTRE68A0EV20100911?feedType=RSS\&feedName=everything\&virtualBrandChannel $=11563$ http://www.aljazeera.com/video/europe/2010/09/201091244237769389.html
} 
reflected in our data, where 1.6 percent of the respondents indicated that they were non-Muslims. We excluded these individuals to focus on Muslims.

Table 1 displays the descriptive statistics of both the independent variables (personal attributes of individuals) and the outcomes. Those who were 12 years of age or older in 1997 would have completed 5 years of elementary schooling and therefore they were exempt from the mandate of the law. These individuals, who were born in 1985 or earlier, are not "treated" by the law; thus they constitute the "control" group. Those who were 10 years old or younger in 1997 were forced to acquire 8 years of schooling instead of 5 years. This group consists of those who were born in 1987 or later and they constitute the "treatment group." Those who were born in 1986 (11 years old in 1997) may or may not have been treated by the law, depending on their birthday. Thus, in empirical analyses we exclude this group. Running the models by including this cohort and assigning them a value of $1 / 2$ or $1 / 3$ for the value of treatment did not change the results.

As shown in Table 1 the proportion of individuals who have at least a middle school degree (eight years of schooling) is higher among those who are in the treatment group in comparison to those who are in the control group. The difference is striking for females. About 54 percent of females who were born before 1986 have a middle school education or more. On the other hand, the rate is 83 percent among those who are exposed to the education reform (born after 1986). Figure 1A displays this information by birth cohort. As mentioned above, those who were born in 1986 constitute the first cohort that is exposed to the policy although it cannot be determined with certainty whether the entire 1986 birth cohort was treated by the reform. The vertical line in Figure 1A identifies this cohort. The full impact of the policy should be felt starting with the cohort of 1987. Figure 1A indicates that the proportion of females with at least 
a middle school education is 51 percent among those who were born in 1980. The rate rises gradually and reaches $58 \%$ in the cohort of 1985 . It goes up to $62 \%$ among those who were born in 1986 and jumps to $71 \%$ in the 1987 cohort and keeps rising. About 92 percent of those who were born in 1995 have at least a middle school diploma. ${ }^{21}$

Consider the case of a student who was born in 1985 and therefore just missed the mandate of the law when it was implemented in 1997. Assume that the parents of this student were not planning to send their children to the middle school prior to the passage of the law. It could, however, be the case that upon the passage of the law the parents might recognize that their child, who just completed 5 years of schooling, could be in a disadvantaged position if he/she is not enrolled in middle school. This is because of the realization that the friends and peers of their child, who are only one or two years younger, will acquire eight years of schooling and this may create a disadvantage for their child in the labor market. If this were the case, children who just missed the mandate of the law (those who had completed the $5^{\text {th }}$ grade right before the law was passed) would enroll in middle school despite the fact that the law was not binding for them.

There is no evidence for this conjecture in the data. Children who were just above the age cutoff do not have higher levels of education than predicted. Children who were born in 1985 just missed the mandate of the law; similarly those who were born in 1984 or earlier were not bound by the law either. Figure 1A shows that none of these cohorts exhibit a spike in middle school completion rate. We ran individual-level regressions where the indicator of

21 We compare this information to the 2012 Turkish Household Labor Force Survey that is obtained from Turkish Statistical Institute. This institute is a government agency, responsible for collecting data on a variety of indicators, ranging from labor markets to financial markets. The Turkish Household Labor Force Survey is similar in its design to the Current Population Survey in the U.S. Using about 80,000 females in the relevant age range, we plotted the proportion with at least a middle school degree in Figure A1 in the Appendix. Appendix Figure-A1 is very similar to Figure 1A. 
having a middle school diploma is regressed on individual level covariates and a linear trend in birth year. We obtained the residuals from this regression, and calculated the mean residual by birth year, which represent unexpected changes in middle school completion rates by birth cohort. Consistent with Figure 1A, there were no outliers, indicating that the level of education of the cohorts that missed the reform did not jump up unexpectedly. ${ }^{22}$

To present the long-run trend in middle school completion, Figure 1B displays the proportion of females with at least a middle school education by birth cohort, going back to those born in 1960. Put differently, Figure 1A is a close-up of Figure 1B, and it is evident that the female middle school completion rate jumps in 1997 after the law was enacted, and stays above its long-run trend.

Table 1 also shows that a similar increase in education is evident in the male sample. Males were more educated than females before the reform, but the proportion of males with at least a middle school degree went up after the reform as well. Seventy-seven percent of males who were not exposed to the reform have at least a middle school degree, while the rate is about 93 percent among those who were treated by the reform. Figure 2A shows the proportion of males with a middle school diploma or higher by birth cohort. The last cohort that missed the reform (those born in 1985) and the first cohort that is fully exposed to it (those born in 1987) have about a 9 percentage point difference in the rate of having at least a middle school diploma. Figure $2 \mathrm{~B}$ presents the trend in male middle school completion rate by birth cohort starting with those who are born in 1960. A comparison of Figures 1B and 2B shows that the proportion of females with at least middle school degree was 20 percentage points lower than that of males in all cohorts from 1960 and 1985, and that the education reform closed the gap significantly: among the cohorts born after in 1990s, the gap is only about five percentage points.

${ }^{22}$ These results are available from the authors upon request. 


\section{Measures of Religiosity}

The survey has posed a question to individuals about their religious beliefs. Specifically, people are asked to indicate whether they are atheist, believer, religious, or devout. ${ }^{23}$ The variable Religious takes the value of one if the respondent indicated that he/she was religious or devout Muslim, and it is zero for those who are atheist or a believer. The reason for classifying those who indicated that they were a "believer" into non-religious category is that in Turkey there is a divide between a person who declared himself as religious and someone who indicated that he was just a believer. A "believer" in Turkey believes in the existence of some power of creation, yet he/she does not necessarily practice religion, or practices selective components of it. For example, two of the five "pillars" of Islam are fasting during the month of Ramadan and praying five times a day. ${ }^{24}$ Islam requires each adult to perform these acts. Surveys show that 94 percent of Turkish Muslims who consider themselves as religious and 98 percent of those who are devout practice fasting during Ramadan, while the rate is only 65 percent among believers. Similarly, 60 percent of the Turkish Muslims who identify themselves as religious and 85 percent of the devout pray five times day, while the rate is only 9 percent among the believers (KONDA 2007). Similarly, alcohol consumption is considered a sin in Islam. In Turkey a Muslim "believer" may consume alcohol, but somebody who declares themselves as religious (dindar) is much less likely to consume alcohol. For example, while only 11 percent of those

\footnotetext{
${ }^{23}$ The exact wording of these alternatives as posed to the individuals are: inancsiz, inancli, dindar, sofu.

${ }^{24}$ The others are declaring that there is one God, and Mohammed is God's messenger; doing pilgrimage to Mecca at least once in a lifetime if the prospective pilgrim is financially secure; and giving out about 2.5 percent of one's net worth to those in need each year.
} 
who declared themselves as religious do consume alcohol, the rate of alcohol consumption goes up to 42 percent among those who declared themselves "believers" in $2011 .^{25}$

We also created a variable, Atheist, which takes the value of one if the person declared themselves a "non-believer" and zero if they indicated that they were a believer, a religious person, or devout. Less than two percent of the sample declared that they were atheists, but despite the small size of this group, there is a statistically significant difference between those who were and were not exposed to the education reform, both for males and for females.

Table 1 shows that about 52 percent of males in the treated group consider themselves as religious, while the rate is about 60 percent in the control group. Similarly, 59 percent of females of the treated group are religious while 70 percent of females on the control group identified themselves as religious. The fact that females in both the treatment and the control groups are more religious in comparison to their corresponding male counterparts is consistent with previous research that has repeatedly shown that women are more religious than men. It has been argued that women are raised to be submissive, which makes it easier for them to accept religion (Suziedelis and Potvin 1981). Similarly, it has been hypothesized that the traditional role of women involves teaching morality and spirituality to their children and this role makes it easier to be religious (Walter and Davie 1998). Miller and Stark (2002) argue that women are more risk averse than men and to the extent that being non-religious constitutes risktaking behavior, the difference in risk aversion between men and women can explain the difference in religiosity. Azzi and Ehrenberg (1975) formulate a model in which agents are making inter-temporal choices, and religious practices and accumulation of religious capital is a time-intensive activity similar to that of accumulation of human capital which can take place through education. In this model women are more religious than men because market wages are

${ }^{25} \mathrm{http}: / /$ konda.com.tr/icki_sigara.pdf 
lower for women than men, generating more (less) incentive for women to invest in religious (human) capital. Also, the model predicts that people optimally delay investing in religious capital until later in life because the return to religious capital can only be realized after death. Instead, people invest in education earlier in life to increase human capital. Thus, this model predicts that religiosity increases in age. This, in part, can explain the difference in the rate of religiosity between the younger individuals who were exposed to the education reform and the older ones who missed the reform. Thus, it is important to control for cohort effects in empirical analyses.

That aging is a potentially important determinant of religiosity is also relevant for the investigation of the propensity for women to wear a headscarf, a turban, or a burka. It is not common among Muslim women in Turkey to wear a burka: the rate of burka-wearing women in the sample is about 1 percent. A "turban" is a symbol of political Islam in Turkey, and it has been the center of a political debate about secularism, freedom of expression and political Islam since the $1980 \mathrm{~s} .{ }^{26}$ It is a piece of fabric, larger than a headscarf, which covers up all of the hair and is tightly wrapped around the neck. ${ }^{27}$ It also involves a narrow piece of fabric on the forehead to make sure that no hair is shown above the forehead. A picture of a woman wearing a turban is provided at the end of the Appendix. Ten percent of women in the sample (ages 18 to 32) have reported wearing a turban. A headscarf, on the other hand, is by far the most common head gear worn by Muslim women in Turkey. Thirty-eight percent of women in our sample wear a head scarf. Thus, about 49 percent of the women in the sample have reported wearing a

\footnotetext{
${ }^{26}$ The details of the turban issue are summarized in the Appendix.

${ }^{27}$ A "turban" does not refer to the type of head gear worn by Sikhs.
} 
head scarf, a turban or a burka. The rate is 59 percent among those in the control group and it is 39 percent among those who were exposed to the education reform. ${ }^{28}$

It is expected that the propensity to wear a head cover would go up after girls transition to being young adults and perhaps after they get married if their husbands put pressure to wear a head scarf. Figure 3A presents the proportion of women wearing a head cover. Even though the proportion of women wearing a head cover is rising with age as expected, the trend shown in the graph between the 1980 and 1985 cohorts is not different from zero. On the other hand, starting with the 1987 cohort, which is the first cohort fully exposed to the law, the propensity to wear a head cover declines dramatically from 52\% in the 1987-cohort to 33 percent in the 1991-cohort (those who are 21 years old in 2012), and to 27 percent in the 1994-cohort (those who are 18 years old in 2012). Figure 3B shows that about 75 percent of women born in the early 1960s (who are around 50 years of age in 2012) wear a head cover and the rate is declining as cohorts get younger. The break in the trend in the birth year of 1986 (26 years olds) is striking.

The respondents of the survey were also asked about their lifestyle. The choices given were "modern," "traditional conservative" and "religious conservative." The dichotomous variable Modern indicates whether the person stated that his/her lifestyle was modern. The question posed to the respondents does not specify what is meant by modern lifestyle. Although interpretations may differ, in the context of the question and the alternatives presented to the respondents, it is clear that modernity is understood as a lifestyle choice including dimensions from what type of clothes to wear to relationship with the opposite sex and social interactions. Table 1 shows that the rate of self-declared modernity is higher in the treatment group for both males and females. Figures 4 and 5 display the rate of modernity by birth year for women and

\footnotetext{
${ }^{28}$ A TESEV report (Çarkoğlu and Toprak, p. 24) found that in 2006 about 49 percent of women wore a headscarf, 11 percent wore a turban and 1 percent wore a burka. These rates are very similar to the rates found in our data.
} 
men, respectively. In both cases there is a clear break in the trend of self-declared modern life style starting with the first cohort that was exposed to the education reform.

The Tendency to Cast a Vote, and the Propensity for Vote for an Islamic Party

The survey included a question which asked the respondents: "If elections were held today, which party would you vote for?" A comprehensive list of political parties is provided to the respondents to choose from, as well as the options of voting for independent candidates, not going to the ballot box, and casting a blank vote. Voter Now is a dummy variable that takes the value of one if the person has identified a political party for which he/she would vote for, or indicated that he/has not yet made up his/her mind as to how to vote. The variable takes the value of zero if the individual indicated that she would not cast a vote. ${ }^{29}$

Similarly, the survey asked the respondents which political party they voted for in the general elections on June 12, 2011. The variable Voter 2011 takes the value of 1 if the person declared he/she has voted for a political party or for an independent candidate. Voter 2011 is zero if the respondent indicated that he/she did not go to the ballot. We also employ an alternative version of this variable by including people who indicated that they went to the ballot box but casted a blank vote.

Using the same survey question we created a binary variable, Islamic Voter Now. This variable takes the value of one if the person indicated that he/she would vote for Justice and Development Party (AKP), Felicity Party (SP), or People's Voice Party (HAS) if elections were held today. ${ }^{30}$ These are Islamic political parties, and the AKP has been the governing party in

\footnotetext{
${ }^{29}$ Turkey, which is governed by democracy since 1923, gave suffrage to women in local elections in 1930. Women gained full suffrage (any type of election) in 1934, and 18 women were elected to the parliament in the general elections of 1935 .

${ }^{30}$ People's Voice Party (HAS) has merged with the Justice and Progress Party (AKP) in September 2012.
} 
Turkey since November 2002. ${ }^{31}$ The variable takes the value of zero if the person indicated that she would vote for any political party, other than the Islamic parties listed above. Political scientists use the term "Islamic Party" to describe a political party that stems from Islamic roots (Fuller 2004; Roy 1994) and as we describe in the appendix this is the case for the parties listed here. In particular, although the Justice and Development Party (AKP) is trying to appeal to a wider voter base, it is clearly an Islamic party (Taspinar 2012, Roy 2102).

Figures 6 and 7 present the proportion of women and men, respectively, who would vote for an Islamic party if elections were held today by birth cohort. In empirical analyses will use the cohorts 1980 to 1994. As shown in Table 1, 66 percent of women born between 1980 and 1985 would vote for an Islamic party now. This cohort missed the education reform. The cohort of 1987-1994 were treated by the education mandate and the proportion of women who would vote for an Islamic party is 56 percent in the group. As shown in Figure 6, this drop is in sharp contrast to the support received by Islamic parties from all cohorts born between 1960 and 1985 . Figure 7 presents the same information for men. The difference in the proportion of men who would vote for an Islamic party today is only five percentage points between the cohorts of 198085 and 1987-94.

We also used the question about how the respondents have voted in 2011 and created a dichotomous variable Voted Islamic in 2011 if the person has voted for an Islamic party in the 2011 general elections. Table 1 shows that there are differences between the treatment and control groups in this variable as well, and the graphs were similar to Figures 6 and 7.

As Table 1 shows, ninety-three percent of the sample adheres to the Sunni sect of Islam, and five percent is Alevite Shiite Muslims. The dichotomous variable Kurt/Zaza takes the value of one if the person identified himself/herself as being of Kurdish or Zaza ethnic origin. Other

31 The details of the Islamic Party movement in Turkey are provided in the Appendix. 
ethnicity takes the value of one if the person is Arabic or of other ethnic origin. The omitted category is being ethnically Turkish.

The bottom panel of Table 1 displays fours variables, which are not employed in benchmark analyses in the paper, but are used in an investigation of potential channels through which education may impact religiosity and the propensity to vote for Islamic parties. Migrant is a dummy variable that takes the value of one if the person has migrated out of his/her region of birth. City and Metropolitan Area are indicators of location of residence. They are mutually exclusive variables where the omitted category is living in rural areas. Metropolitan Area identifies the metro centers of 16 cities that are governed by special municipal structures. ${ }^{32}$ Labor Force Participation takes the value of one if the person is working or looking for work, and zero otherwise. Only about 25 percent of women participate in the labor market.

\section{Empirical Specification and the Basic Results}

Our primary purpose is the investigation of the impact of education on outcomes such as religiosity, the propensity to vote in general elections and the propensity to vote for an Islamic party. More specifically, consider equation (1) below.

$$
\mathrm{R}_{i}=\beta_{0}+\beta_{1} E d u c_{i}+\mathbf{X}_{i} \boldsymbol{\Omega}+\boldsymbol{\varepsilon}_{i}
$$

where $\mathrm{R}_{\mathrm{i}}$ represents a particular outcome, such as whether the person wears a head cover or whether they have voted for an Islamic party. Educ is an indicator to show whether the person has at least a middle school education (eight years of schooling). The vector X stands for personal characteristics of the individual, including age, ethnicity, the religious sect, and the

\footnotetext{
32 They are Istanbul, Ankara, Izmir, Bursa, Adana, Kocaeli, Gaziantep, Konya, Antalya, Kayseri, Diyarbakir, Mersin, Eskisehir, Sakarya, Samsun and Erzurum.
} 
location of residence. Vector $\mathrm{X}$ also contains survey region fixed-effects and month dummies to control for the month and location in which the survey was registered. It also includes fixedeffects for the region-of-birth of the respondent.

Because unobserved determinants of religiosity and other outcomes of interest (R), captured by the error term $\varepsilon$, are likely to be correlated with education, we use exposure to the 1997 law as an instrument for education. Specifically, the law was designed to increase the minimum level education from 5 to 8 years. Thus, the first stage regression is

(2) $\quad \mathrm{Educ}_{i}=\gamma_{0}+\gamma_{1} L a w_{i}+\mathbf{X}_{i} \boldsymbol{\Psi}+\mu_{i}$

where Law is a dummy variable that indicates whether the individual was treated by the law. It takes the value of one if the person was born in 1987 or later, and it is zero if the person was born before 1986. In all regressions the estimated standard errors of the coefficients are clustered by region of birth--age group. Alternatively, we cluster the standard errors by treatment status--region. This specification provides only 24 clusters as there are 12 regions; therefore the standard errors obtained from this clustering should be interpreted with caution, although as we report in the tables the standard errors obtained from two alternative clustering methods are similar. In an alternative specification, we included those who were born in 1986 and assigned them the value of 0.33 or 0.50 as alternative values of the treatment. The results, presented in the Appendix, are very similar to our main estimates.

\section{The Impact of the Law on Educational Attainment}

Table 2 displays the results estimating equation (2) for the whole sample as well as for males and females separately. The regressions are estimated by OLS and the standard errors of 
the estimated coefficients are clustered by age-region of birth, as well as by treatment statusregion of birth. Column (1) shows that in the whole sample, exposure to the law increases the propensity to have at least a middle school education by 10 percentage points. At the sample mean of 0.77 , this represents a 13 percent increase in the probability of having at least eight years of education. The result for males in column (2) indicates a 6 percentage point impact, which translates into a 7 percent increase in the probability of having at least a middle school education. Column (3) shows that the impact of the law is stronger for females (about 14 percentage points), which is a 20 percent increase at the sample mean of 0.67 . In summary, the results in Table 2 reveal the effectiveness of the reform in terms of increasing educational attainment, especially for females.

We also investigated the impact of the reform on the probability of completing at least high school and having at least a college degree. The results, which are presented in Appendix Table A2, show that the reform had spillover effects and it also impacted the probability of having a high school diploma as well as a college degree. Column (1) of Table A2 reports the results of a falsification test. It shows the impact of the exposure to the reform on the propensity to complete 5 years of primary schooling. As expected, the reform has no impact on the propensity to complete at least five years of schooling.

The Impact of Education on Religiosity, Electoral Participation, and the Propensity to Vote for Islamic Parties

Table 3 displays the instrumental variables regressions results for the whole sample, where middle school education is instrumented with the treatment dummy. The bottom section of each column reports the F-value of the instrument from the first-stage. The F-values are 
mostly in the range of 20-24, indicating the strength of the instrument. Column (1) shows that having at least a middle school diploma, as opposed to elementary school education, decreases the propensity to be religious by about 40 percentage points. This impact, which is generated by three extra years of schooling, implies that one additional year of education reduces the propensity of being religious by about 13 percentage points, or by 22 percent at the sample mean. Similarly, column (2) of table 3 demonstrates that an increase in education increases the probability a person declaring himself/herself atheist, and column (3) shows that having at least 8 years of middle school education as opposed to five years of elementary school, increases the propensity to identify one's lifestyle as modern instead of conservative or religious. ${ }^{33}$

Column (4) of Table 3 displays the results of the IV regression where the dependent variable is an indicator that shows whether the person has casted a vote in the 2011 general elections. Column (5) presents a similar regression, where the dependent variable takes the value of one if the person has indicated that he/she would vote if elections were held this Sunday, and zero otherwise. In both cases, education has no impact on the propensity to vote. ${ }^{34}$ This result is in contrast with studies that reported a positive impact of education on civic participation in developed countries.

Columns (6) and (7) present the results where the dependent variable is an indicator of whether the person has casted a vote for an Islamic party in 2011 general elections, or whether he/she would vote for an Islamic party if elections were held this Sunday (in 2012), respectively.

\footnotetext{
${ }^{33}$ In the regression of atheism in Table 3 , only 138 people ( $1.4 \%$ of the sample) are atheists. These individuals, however, reported a religious sect such as Sunni or Alevite Shii'te, suggesting that for them this is cultural, rather than religious identity.

${ }^{34}$ In Turkey voting is compulsory and there is a monetary penalty associated with non-voting. Although the 22.5 Turkish Lira penalty (about \$13) for not voting is not substantial, and enforcement is spotty, compulsory voting which has been in effect since 1986 is likely the reason for high rates of voter turnout which is usually greater than 85 percent.
} 
The results indicate that an additional year of education reduces the probability of casting a vote for an Islamic party by 19-26 percent (given the point estimates and the baseline probabilities).

Column (6) of Table 3 analyzes how the respondents voted in the elections of June 2011 and column (7) investigates how they would have voted now (in 2012). Given the short time distance between these two events, we expect that most respondents would not have changed their voting preferences. Table 4 displays the distribution of people with respect to how they voted in 2011 and how they would vote if an election were held in 2012. Not surprisingly, the majority are not inclined to change their minds. Specifically, information is available on 5,834 people on regarding how they voted in 2011 and also how they would vote now. Three thousand-one hundred seventy nine of them (54.5 percent) indicated that they voted for an Islamic party in 2011 and they would vote again for an Islamic party today, while 40.3 percent revealed that they have not voted for an Islamic party and they would not vote for an Islamic party today. Five percent of this sample indicated that they would switch their vote. The bottom section of each cell in Table 4 displays the proportion of voters in each group that has at least a middle school diploma. For example, among those who have not voted and who will not vote for an Islamic party, the proportion with at least a middle school diploma is 0.84 . Among those who would switch away from Islamic parties, the proportion with a middle school education is 0.81 . Those who would switch to an Islamic party have on average lower levels of education: 74 percent of this group has at least a middle school diploma and the rate is 0.66 among those who voted for an Islamic party in 2011 and who would vote again for an Islamic party today.

Although voting preferences are highly consistent between 2011 and 2012, it is useful to classify voters into two groups and investigate the extent to which education impacts movement 
between these two groups. In this analysis the first group consists of those who have not voted for an Islamic party in 2011 and who declared that they would not vote for an Islamic party today either. For these voters the variable Never Vote Islamic takes the value of one. These individuals are in cell $\mathrm{D}$ of Table 4 . This variable takes the value of zero for individuals who have voted for an Islamic party in 2011 and/or indicated that they would vote for an Islamic party today. In other words, Never Vote Islamic takes the value of zero for those who are in cells A, B, or C in Table 4. The result, reported in column (8) of Table 3 are consistent with those reported in columns (6) and (7). An increase in education, generated by the reform, increases the propensity for having political preferences that are consistently against Islamic parties.

The control variables used in these regressions reveal insights into religiosity and political preferences. For example, being a Sunni Muslim (as opposed to being an Alevite Shii'te Muslim or being an adherent of another sect of Islam) has a significant positive impact on the propensity of being religious and a negative impact of being an atheist. It also has a negative impact on the propensity to self-identify as having a modern life style. Being a Sunni has also a significant impact on the propensity to vote for Islamic parties. Being an Alevite Shii'te has the exact opposite effects as being a Sunni. People of Kurdish or Zaza ethnicity have higher probability of being an atheist in comparison to Turks (which is the left-out category in the regressions). Kurds and Zazas are less likely to vote for Islamic parties. A potential reason for this result is the fact that Kurds are more likely to vote for BDP, which is a political party with Kurdish identity.

Table 5 reports the same regressions as in Table 3, but they are estimated using the sample of females. The survey includes one additional measure of religiosity, pertinent for Muslim women: whether they wear a head cover such as a headscarf, turban or burka. The 
regression using this variable reported in column (4) of Table 5. The results show that an increase in secular education lowers religiosity, increases modernity, and reduces the propensity to wear a head cover for women. Specifically, a middle school diploma reduces the propensity for women to declare themselves as religious by about 30 percentage points (about 45 percent). It increases their propensity to declare themselves as being modern by 29 percentage points, (about 85 percent), and reduces the propensity to wear a head scarf, religious turban or burka by about 40 percentage points ( 82 percent). Education also has a significant negative impact on the propensity to vote for Islamic parties. Thus, Table 5 demonstrates that, in case of females, secular education has a substantial impact on religious attitudes and political tendencies that are influenced by religion.

Table 6 shows that in case of men, education has no impact on either religiosity or the propensity to vote for an Islamic party. It should be noted, however, that the first-stage regressions are not very powerful in the regressions for men, with F-values around 6.

To gain additional insight, we ran reduced form regressions, where the outcomes are regressed on the treatment dummy that identifies the cohorts that are exposed to the education reform as well as on other control variables. The results, presented in Appendix Table A5, are in line with our main estimates presented in Tables 3, 5, and 6. For instance, for men in Panel C, the impact of the treatment by the law is not significant in any outcome other than Voter 2011, suggesting that we cannot reject the hypothesis that increased education has no meaningful impact on religiosity and the political support of Islamic parties in case of men.

For the purpose of comparison, we also ran the models using OLS, instead of instrumental variables. In these specifications, education is considered exogenous. The results, which are displayed in Appendix Table A6, show that OLS coefficients of education are smaller 
than the instrumental variables coefficients reported in Tables 3, 5, 6 and that the impact of education is statistically significant for males as well as for females.

\section{The Impact of Economic Circumstances}

The dependent variable "Islamic Voter Now" measures whether people would vote for an Islamic party if general elections were held today. This question, as all other questions in the survey, was posed to the respondents in 2012. The 2011 elections were won by an Islamic party (AKP), and therefore Turkey was governed by an Islamic party in $2012 .^{35}$ Thus, a declaration in favor of voting for a non-Islamic party in 2012 could reflect a person's dissatisfaction with the policies of the current Islamic government. While the survey does not include questions about approval of government policies, it includes questions about personal economic circumstances of the respondents. Specifically, the variable "Can Make Ends Meet" takes the value of one if the respondent indicated that he/she was financially comfortable and could even save some money last month, or although not comfortable financially, managed to make ends meet last month. The variable takes the value of zero if the person indicated financial difficulty, difficulty in paying the bills, or having the need to borrow money to make ends meet last month. Along the same lines, we employ a variable that asks the respondents whether they "expect personal economic hardship during the next months." The variable Expect Personal Economic Hardship takes the value of one if the respondent answered in the affirmative. Our hypothesis is that, all else the same, individuals who have difficulty making ends meet or who expect personal economic hardship would be more inclined towards voting against the current Islamic government. If less educated individuals face economic hardship and if they intend to cast a vote against the current government as a result of their difficult economic circumstances, then their propensity to vote

\footnotetext{
${ }^{35}$ In fact, AKP has governed Turkey since 2002.
} 
against Islamic parties (the strongest one of which is the governing AKP) may be misconstrued as the impact of education. Under this scenario, the impact of education would be biased away from voting for an Islamic party. Alternatively, younger cohorts, who are more educated, may face tougher economic challenges and/or they may be more pessimistic about their economic future in comparison to older and less-educated cohorts. In that case, the younger and the more educated would cast their vote against the current Islamic government, not because of the causal impact of education but because of their own economic circumstances.

Table 7 presents the results of the models where Islamic Voter Now is regressed on the same set of explanatory variables and middle school completion is instrumented with the exposure to the education reform as before. These models, however, include the two new variables that gauge personal economic circumstances of the individuals. Column (1) displays the results obtained from the full sample. Columns (2) and (3) pertain to males and females, respectively. In all cases, people who expect personal economic hardship in the months ahead are less likely to vote for an Islamic party. Specifically, males (females) who expect personal economic hardship are 14 (10) percentage points less likely to vote for an Islamic party if elections were held today. ${ }^{36}$ The coefficient of Make Ends Meet indicates that females (males) who stated that they could make ends meet this month are $9(6)$ percentage points more likely to vote for an Islamic party. ${ }^{37}$ These results indicate that voters who are concerned about their own economic well-being plan to vote against the Islamic party that was in power in 2012. On the other hand, controlling for these variables that gauge personal economic circumstances has no effect on the magnitude of the estimated coefficients of education. For example, the

\footnotetext{
${ }^{36}$ In the sample used in regressions of column (1) of Table 7, the mean of Expect Personal Economic Hardship is 0.38 in the treatment group, and it is 0.36 in the control group. The difference in these means is not different from zero.

${ }^{37}$ The mean of Can Make Ends Meet is 0.79 in the treatment group and it is 0.75 in the control group, and the difference is statistically significant.
} 
coefficient of Middle School Diploma is -0.422 in column (1) of Table 7, and it was -0.419 in the same specification that excluded economic circumstance variables (column 7 of Table 3). Similarly, the coefficient is -0.545 for females in Table 7 , and it was -0.537 in column (8) of Table 5. In case of men, even though the impact of education is not statistically different from zero, the point estimates are very similar between the model that included economic well-being variables --column (2) of Table 7 and the model that excluded them - column (7) of Table 6. These findings indicate that while economic well-being has an impact on the propensity to vote for-or-against the governing political party, education has a direct separate impact on the tendency to support Islamic parties.

\section{Robustness Checks and the 2008 Data}

To investigate the robustness of the results, we estimated a number of alternative specifications. Some individuals who were born in 1986 were impacted by the law, while others of the same cohort were exempted by the law, depending on the exact birth day. Therefore, the regressions reported in the paper excluded the 1986 cohort. We, however, estimated the models by including those who were born in 1986 and assigning them the value of 0.5 or alternatively, 0.3 for the treatment. The results, reported in the Appendix Tables A3 and A4, were extremely similar to those obtained from the benchmark specification. Second, we used years of completed schooling, rather than a dichotomous indicator of whether the person has at least a middle school diploma. The results remained the same and the estimated coefficients were about one-third of those reported in the paper.

Third, we excluded people who are enrolled in school and re-estimated the models. This is potentially important in case of wearing a head cover because it was against the law in 2012 to 
wear a head cover inside of most public institutions, including schools. The results are presented in Appendix Table A7. Although sample sizes get smaller when we drop students, the estimated impact of the middle school diploma has not changed substantively either in magnitude or in statistical significance.

Our data set is based on a survey done in 2012. Younger individuals in the data (18-25 year old in 2012) are treated by the reform, while older ones (27-32 years old in 2012) are not exposed to the reform. All regressions control for linear and quadratic age, but it could still be argued that some unobserved factors might have impacted those who are 25 or younger in comparison to those who are 27 or older, and that this could be the reason for identified impact of education. To address this point, we use a survey conducted in 2008 by the same company (KONDA) that provided the data used in the paper. The 2008 survey is smaller in sample size, but is nation-wide and it includes the same questions on modernity and wearing a head cover (head scarf, turban or burka) as well as information on other key variables that are employed in regressions, including education, age, religious sect and ethnicity.

Using both the 2012 and the 2008 data sets we investigate whether the results could have been driven by cohort effects. Consider Table 8 , which summarizes the cohort information pertaining to the 2012 data used in the paper, as well the information on the 2008 data. Specifically, columns (1) and (2) of Table 8 display the year of birth and exposure to the law, and column (4) shows the age of the individuals in 2012. For example, someone who was born in 1984 was not exposed to the law, and he/she was 28 years old in 2012. Column (3) shows the age of the same people in 2008 .

From the 2008 data we extract those who were 23,24 or 25 year old in 2008 . The descriptive statistics of the group are provided in the left panel of Appendix Table A8. We also 
extract people of the same age group from the 2012 data. These two groups are represented by the two boxes in Table 8, connected by arrow A. Those who are 23, 24 or 25 years old in 2012 are treated by the reform, but those who are 23, 24 or 25 in 2008 are not exposed to the reform. Thus, we create a sample of 23-25 year olds using both the 2008 and 2012 surveys and assign a value of 1 for the treatment dummy for those who are surveyed in 2012, and zero for those who are surveyed in 2008. Regressions using this sample allow us to investigate if the results are driven by the age difference between the treatment and control groups. Similarly, we also create a sub-sample and run the instrumental variables regressions using those who are (23 or 24$)$ in 2008 or in 2012.

The results are reported in Table 9. All regressions in the table include every control variable used in previous regressions including region of survey fixed-effects and region of birth fixed effects. In addition, they include year-of-birth dummies to account for the fact that although individuals in this sample are in the age range of 23-25, their year of birth ranges from 1983 to 85 and from 1987 to 1989 (see table 8). Panel A of Table 9 displays the results that pertain to the sample of 23-to-25 year olds. Column (1) presents the results of the instrumental variables regression for men where the dependent variable is Modern. The sample consists of 1,258 observations and about 83 percent of these come from the 2012 survey. The first-stage regression is powerful with an F-value of about 30 and the estimated coefficient of middle school education indicates that having at least a middle school diploma increase the propensity for modernity by 84 percentage points for men. Column (2) presents the same regression for females and demonstrates that education has a positive impact on modernity, which is not significant at conventional levels. This sample consists of 1,211 women who are 23 -to-25 years of age, and only 215 of them come from the 2008 survey (for whom the treatment value is equal 
to zero). This means that the imprecision of the estimate may be due to small variation in the treatment. Despite small variation in the treatment variable, column (3) shows that education has a significantly negative impact on the propensity to wear a head cover.

Panel B of Table 9 displays the same results, but these samples use individuals who are 23 or 24 years old in 2008 or in 2012 . Thus, these samples are smaller, but the results are consistent with those reported in Panel A. ${ }^{38}$ In summary, the results in Table 9 indicate that the impact of education reported in Tables 3-7 in the paper are not due to the age difference between those who are exposed to the education reform and those who are not exposed.

We conduct another test to investigate whether age effects are responsible for the estimated impact of education. In our primary analysis sample, age is negatively correlated with education. More precisely, younger individuals had exposure to the education reform while older individuals were not treated by the law. We simulate a scenario to test whether ageing of the same cohort can explain the variation in religiosity. Consider those who are 23-to-25 in 2008. This group is not exposed to the reform. Four years later, in 2012, this group becomes 27-29 years old. We create a sample, consisting of individuals who are 23-25 in 2008 and those who are 27-29 in 2012. We assign a placebo treatment, which takes the value of 1 for those in the younger group (23-25) and zero in the older group (27-29). Note again that nobody in this sample is exposed to the treatment by the reform. However, if being young alone is responsible for less religiosity and more modernity, then our placebo treatment ( $T=1$ for ages 23-25 of the 2008 survey, and $\mathrm{T}=0$ of $27-29$ of the 2012 survey) should explain these outcomes. (See Arrow B in Table 8).

\footnotetext{
${ }^{38}$ The exception is column (2) where the first-stage is not powerful and the estimated coefficient of education is greater than one.
} 
Tables $10 \mathrm{~A}$ and $10 \mathrm{~B}$ present the results of this analysis. Table 10A displays the results where the dependent variable is an indicator of having at least a middle school education. This table is counterpart of Table 2. In addition to standard explanatory variables, regressions also control for year-of-birth dummies. Because neither the individuals from the 2008 survey nor those from the 2012 survey are exposed to the law in this sample, their education level is not expected to be different from each other. This is confirmed in Table 10A, where the coefficient of the placebo treatment dummy is not different from zero. This, in turn indicates that the instrumental variables regressions that use the placebo dummy as an instrument for education would be meaningless. Instead, we run reduced form regressions where modernity and wearing a head scarf are regressed on the full set of explanatory variables and the placebo treatment dummy. This specification investigates whether religiosity of individuals of the same cohort (born in 1983, 1984 or 1985; see Arrow B in Table 8) changes as they get older. Table 10B displays the results. Each regression includes the explanatory variables used previously, as well as year-of-birth fixed effects. The key variable is titled Exposure to the Placebo Law, which takes the value of one for those who are 23-25 years old in 2008, and takes the value of zero for those who are 27-29 in the 2012 survey. As Table 10B shows, the estimated coefficients of Placebo Treatment are small and not different from zero, indicating that being young is not a confounder of the impact of education on religiosity reported earlier.

\section{Difference-in-Difference}

Finally, we estimate a difference-in-difference specification. We consider individuals who are $23-25$ or 27-29 in 2012. These are the people who are on both side of the education reform: those who are 23-25 in 2012 were treated by the reform, while those who are 27-29 
missed it. ${ }^{39}$ We also consider people of the same exact age from the 2008 survey (the descriptive statistics of this group of individuals surveyed in 2008 are provided in the right-hand side panel of Appendix Table A8). Although the 2012 and 2008 groups are of the same age, nobody in the 2008 group is exposed to the reform. We create a dummy variable Young, which takes the value of one if the person is 23 -to- 25 years old, and zero otherwise. We create a second indicator variable, Year2012, which identifies whether the individual was surveyed in 2012. This design is depicted by arrows $\mathrm{C}$ in Table 8 .

We estimate the following model.

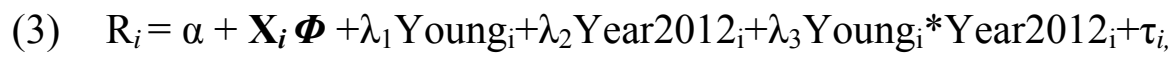

where $\lambda_{1}$ is the impact of being young (as opposed to being 27-to-29 year old) in 2008 on modernity or on the probability of wearing a head cover, and $\lambda_{3}$ represents the dif-in-dif magnitude: it is the differential impact of being young in 2012 versus being young in 2008. As the young group surveyed in 2012 has been treated by the reform while their counterparts surveyed in 2008 have not, $\lambda_{3}$ is an estimate of the reduced form effect of the exposure to the reform.

The results are presented in Table 11. In column (1), which displays the results of the regression where the dependent variable is modernity for men, the dif-in-dif estimate is not statistically different from zero. In column (2), which pertains to women, the estimate is 0.09 and significantly different from zero. Similarly the dif-in-dif estimate in column (3) indicates an impact of 11 percentage-point reduction in the probability of wearing a head cover. Thus, the dif-in-dif estimates confirm the results provided by the instrumental variables regressions.

${ }^{39}$ As we have done throughout the paper those who are 26 years old in 2012 are excluded in the benchmark models because some individuals of this cohort may be exposed to the law while some other are certainly not exposed. 


\section{Regional Heterogeneity}

In this section we investigate if the results are location-specific. While our data set is not big enough to estimate the models by region, it can be coherently divided into two broad segments as Eastern Turkey and Western Turkey. ${ }^{40}$ These regions differ systematically in a number of dimensions, ranging from economic development to cultural conservatism, where Western Turkey enjoys higher per capita income and higher levels of schooling. Some of the major cities such as Istanbul and Izmir are in the West, while some others such as the capital city Ankara, are in the East.

Figures $8 \mathrm{~A}$ to $9 \mathrm{~B}$ present the proportion of women and men with middle school education in the East and in the West. There is a visible increase in the rate of middle school completion following the reform in both regions, which is especially pronounced for women. In Appendix Table A9 we present the results of models where probability of having at least a middle school diploma is regressed on full set of control variables and a variable capturing the treatment to the education reform. These are the same specifications as in Table 2, but in this table we report these education regressions by region (East v. West) and gender. Panel A of Table Appendix A9 replicates Table 2 as these results are obtained from the whole sample. The results shown in panels B and C of Appendix Table A9 show that the impact of the reform has been larger on women than men in both Eastern and Western Turkey. The impact has been smallest in magnitude on men in the West, which is not surprising given that their middle school completion rates were the highest among the four groups. These results indicate that the impact of the

\footnotetext{
40 The former groups consists of Central Anatolia, The Black Sea Region, Northeast Anatolia, North Central Anatolia and Southeastern Anatolia. The latter group consists of Istanbul, West Marmara, East Marmara, The Aegean Coast, Western Anatolia and the Mediterranean Coast.
} 
education reform was not contained to a specific area, but rather it was felt throughout the country.

Figures 10 to 15 display the outcomes analyzed in the paper among women who reside in the East or in the West by birth cohort. Figure 14, which presents the proportion of women in Eastern Turkey who would vote for an Islamic party if elections were held in 2012, displays no clear break between the cohorts that are/are not exposed to the law. In all other cases, the reform seems to have impacted the outcomes analyzed.

Appendix Table A10 presents the instrumental variables regressions that are estimated separately for women in Eastern and Western Turkey. These are the 1980-1994 cohorts of women who are behind Figures 10-15. The number of observations in the Western sample ais more than 3,000 in most regressions and the first-stage F-values are close to 10 in most cases. Consequently, regressions on Western Turkey are estimated with reasonable precision and the results are consistent with those obtained from the sample of all women. The sample of women from the East, on the other hand, is much smaller with 900-1,300 observations and the first-stage F-values are around 4. As a result, not much can be inferred from the regressions using the subsample of women from Eastern Turkey.

\section{Potential Mechanisms}

The effect we identify in the paper represents the total impact of secular education on religiosity and on the propensity to vote for Islamic parties. This total impact can work through a number of channels. For example, education can increase cognitive ability, analytical thinking skills and appreciation of scientific analysis, all of which can influence religiosity. Furthermore, going to school during adolescence may increase the network of friends which could allow 
exposure to a variety of viewpoints and experiences, which in turn may impact preferences. Increased education could also lead to migration, and moving from rural areas to cities and residing in a big city may also influence preferences in a number of dimensions, including religion. Furthermore, education may increase the propensity to participate in the labor force, which may also alter religiosity.

To investigate whether any of these factors have an influence on the estimated impact of education, we re-estimate the same specification for women as in the benchmark model displayed in Table 5, but we include additional variables that measure the location of residence (City, Metro Area vs. rural), whether the person has migrated out of the city she was born (Migrant), and whether the person is in the labor force (Labor Force Participation). ${ }^{41}$ Table 12 presents the results. For the sake of comparison, Panel A displays the coefficients of education reported in Table 5. These coefficients represent the total effect of education. Panel B displays the results of the models that include migration and labor force participation and residential location variables. The coefficients on these variables are consistent with priors in that if the person is a migrant she is less likely to vote, and more likely to self-identify as modern. Women living in metro areas are less likely to be religious, less likely to wear a religious head cover and more likely to be modern. The same is true for women who are in the labor force: they are less likely to be religious, less likely to wear a religious head gear, and more likely to indicate that they have a modern life style.

A comparison of the coefficients of the middle school diploma between the panels A and B of Table 12 shows that they are very similar, although statistical significance is reduced in same cases in Panel B. For example, in columns (1) and (3) we observe that adding variables

\footnotetext{
${ }^{41}$ This exercise is in the same spirit as Hamermesh and Abrevaya (2013), Mocan and Tekin (2010), and Cullen, Jacob and Levitt (2005).
} 
which measure the immigration status, labor force participation behavior and the location of residence changes the coefficient of education by only about 16 percent in the religiosity and modernity regressions (from about -0.29 to -0.25 ). The coefficient of education changes only slightly from -0.399 to -0.339 in the religious head cover regression of column (4), and the education coefficients in regression on voting for Islamic parties are almost the same between the two specifications. These results suggest that migration, choice of residential location or labor force participation are not likely channels through which education impacts religiosity and preferences for Islamic parties.

\section{Summary and Discussion}

Education is shown to change individuals' preferences in a number of dimensions, ranging from time discounting to intolerance for violence. Whether education affects religiosity, however, has been a difficult question to answer because of the empirical challenge it presents. An exogenous change in education has to be identified that would have an influence on some individuals, but that would have no impact on others in an effort to tease out the causal impact of education on religiosity from other correlates and confounders.

The impact of education on religiosity is also important to investigate because of the implications for political economy of development. During the last decade there has been a surge of political Islam in the Middle East and North Africa. ${ }^{42}$ As shown in Table A1 in the Appendix, these countries are characterized by low per capita income, low levels of education, low level of democracy and high religiosity. If secular education has a causal impact on religiosity and on voter preferences for Islamic parties, education policies can impact political landscape of these developing countries.

${ }^{42}$ With the exception of Israel and Cyprus, the predominant religion in these countries is Islam. 
In this paper we exploit an education reform in Turkey that was implemented very quickly and rather unexpectedly in 1997. A law that was passed in August 1997 increased the mandated years of education from 5 to 8 years for those students who were about to start the fifth grade or lower in the Fall of 1997. Students who had completed five years of schooling before the fall of 1997 were not bound by the new law.

We employ a unique nationally-representative data set that gauges the extent of religiosity and voting behavior of individuals in Turkey in 2012. In addition, the data set includes information that is not available in standard data sets, such as ethnic background of the survey respondents (e.g. being Kurdish or Arabic), as well as information on the religious sect of the individuals, such as whether they are Sunni-Muslim or Alevite Shii'te.

We investigate the extent to which an increase in education, generated by the reform has an impact on individuals' religiosity in this predominantly Muslim country. Religiosity is measured by whether individuals are atheists, believers, religious Muslims or devout Muslims. We also investigate the impact of education on self-declared lifestyles such as being a religious conservative, conventional conservative, or modern. In case of women, we analyze whether an increase in education has an impact on a strong indicator of religiosity in Islam: the propensity to wear a head cover such as a head scarf, or burka, or a religious turban. Importantly, the data set includes information on the specific political party the individuals have voted for in the 2011 general elections and how they would vote if elections were held today. Using this information we investigate the impact of education on the propensity to participate in elections as a voter and on the propensity to vote for an Islamic party. 
We first analyze whether the education reform has in fact increased educational attainment, and find that exposure to the reform has increased the propensity to have at least a middle school education ( 8 years). The impact is particularly strong for females.

We use exposure to the reform, determined by the year of birth, as an instrument for educational attainment. Instrumental variables regressions show that in case of women, education lowers the propensity for being religious, and it decreases the probability of wearing a head/body cover such as a headscarf or burka. Education increases the propensity for women to identify themselves as having a modern lifestyle. On the other hand, education has no impact on men's religiosity. For both men and women, education has no impact on electoral participation; that is, increased education does not make individuals more likely to vote in a general election. This result is in contrast to the research on developed countries which, in general, identified a positive impact of education on voter turnout.

Finally, and importantly, we find that education makes women less likely to vote for an Islamic party. This is true for those who have voted in the 2011 elections and in the analysis of how they would vote if elections were held today. Because in 2012 Turkey was governed by a party with Islamic roots (Justice and Development Party -AKP), the tendency to cast a vote against this party today could in part be a reflection of dissatisfaction with current economic circumstances. We control for two variables that gauge whether individuals face economic difficulty and whether they foresee personal economic hardship in the months ahead. While these variables negatively impact the propensity to vote for the incumbent Islamic party, inclusion of these variables in the models had no influence on the negative impact of education on the propensity to vote for the governing Islamic party. For men, the impact of education on 
the propensity to vote Islamic is not different from zero. The results are robust to how the 1986 cohort is treated, and to the exclusion of current students from the analyses.

Our data set is from the year 2012, and younger individuals in the data (18-25 year old in 2012) have been exposed to the education reform, while older ones (27-32 years old in 2012) were exempt from the mandate of the reform. Although all regressions control for age, it can still be argued that some unobserved factors might have impacted those who are 25 or younger in comparison to those who are 27 or older, and that this could be the reason for the identified impact of education. Even though the dramatic change in behavior that is presented in the graphs indicate that this is not likely the case, we address this concern by using a smaller but similar survey from 2008 that includes all key variables and information on individuals' modernity, and in case of women, whether they wear a head cover. Using these two years of data enables us to conduct a variety of tests, including a dif-in-dif specification, which show that the identified impact of education is not due to a cohort effect.

These results show that education alters women's preferences on religiosity and their political tendencies to vote for an Islamic party. It is interesting that no such statistically significant impact of education exists for men. Middle school education, which is mandated by the new law, consists of a standard curriculum including a wide range of courses from mathematics to literature, from history to geography. While exposure to such subject matters and the corresponding increase in cognition may alter preferences, the difference in the impact of education between males and females may suggest that the change in preferences may not be driven by what is taught in the classroom. An alternative explanation could involve being "outside of the home." It should be noted that female labor force participation is low in Muslim countries and Turkey is no exception. The labor force participation rate of women ages 15 to 24 
was $32 \%$ in 1997 , while the rate was double $(63 \%)$ for men in that same year. This difference, stemming from both economic and cultural factors, indicates higher rates of girls and young women stay at home. Thus, it could be the case that the education mandate allowed girls to have exposure to a larger network of friends, ideas and experiences, and enabled them to socialize outside the home and to participate in society more heavily via school attendance between the ages of 12-15, when such experiences could have long-lasting effects. ${ }^{43}$ Although we cannot test this socialization hypothesis directly, we show evidence in the paper to indicate that migration out of the city of birth, labor force participation, or the location of residence are not likely channels through which education impacts religiosity and the propensity to vote for an Islamic party.

\footnotetext{
${ }^{43}$ This explanation is consistent with that reported by Cannonier and Mocan (2012) who found that exposure to an education reform in Sierra Leone has changed the preferences of women regarding matters that impact women's well-being, although the quality of schooling received was likely very low.
} 
Figure $1 \mathrm{~A}$

Proportion of Females with at Least Middle School Education in 2012 Birth Cohorts 1980 to 1994

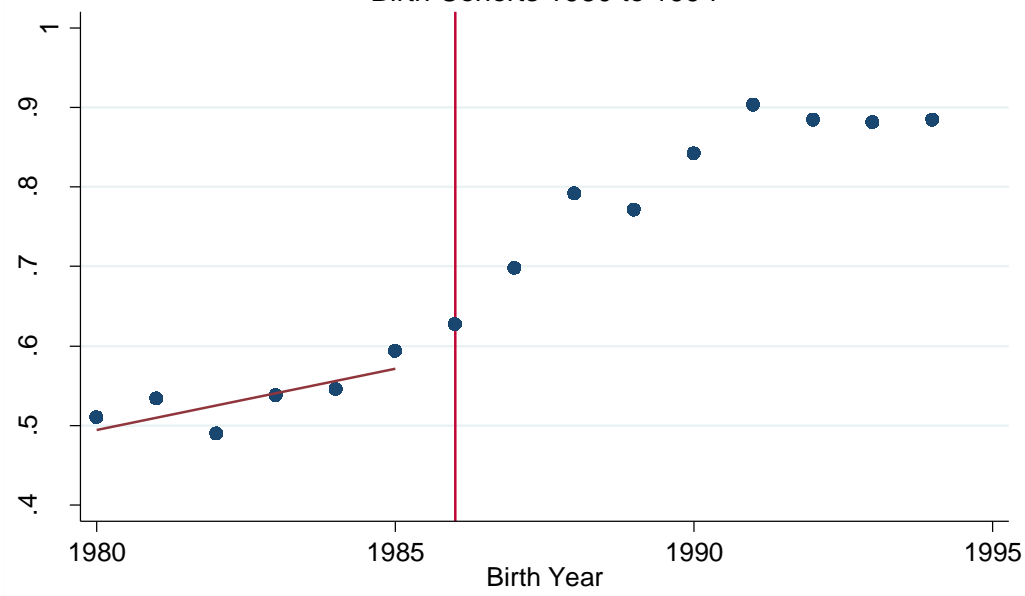

Figure 1B

Proportion of Females with at Least Middle School Education in 2012 Birth Cohorts 1960 to 1994

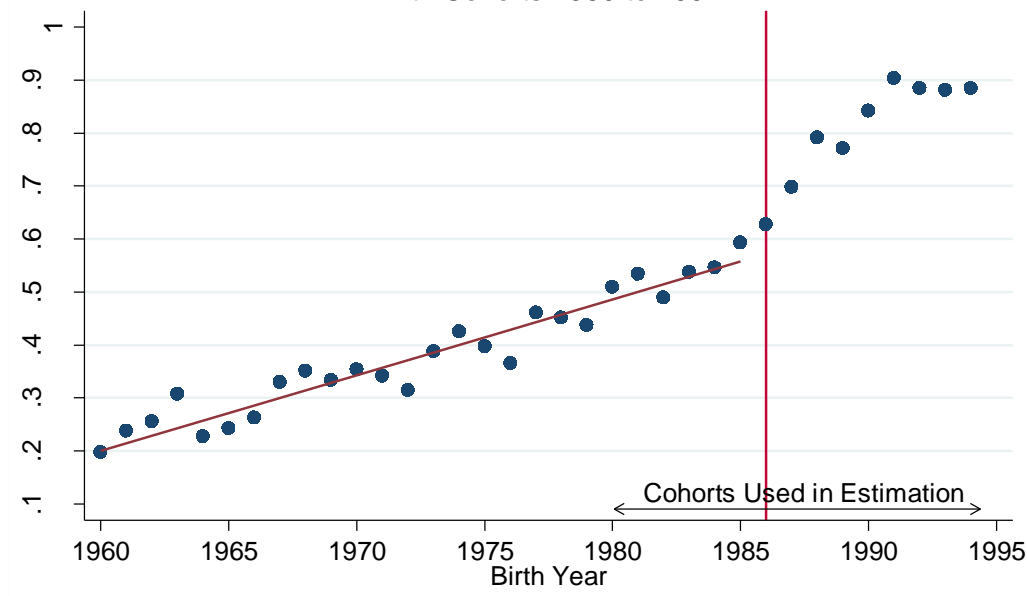

Figure 2A

Proportion of Males with at Least Middle School Education in 2012

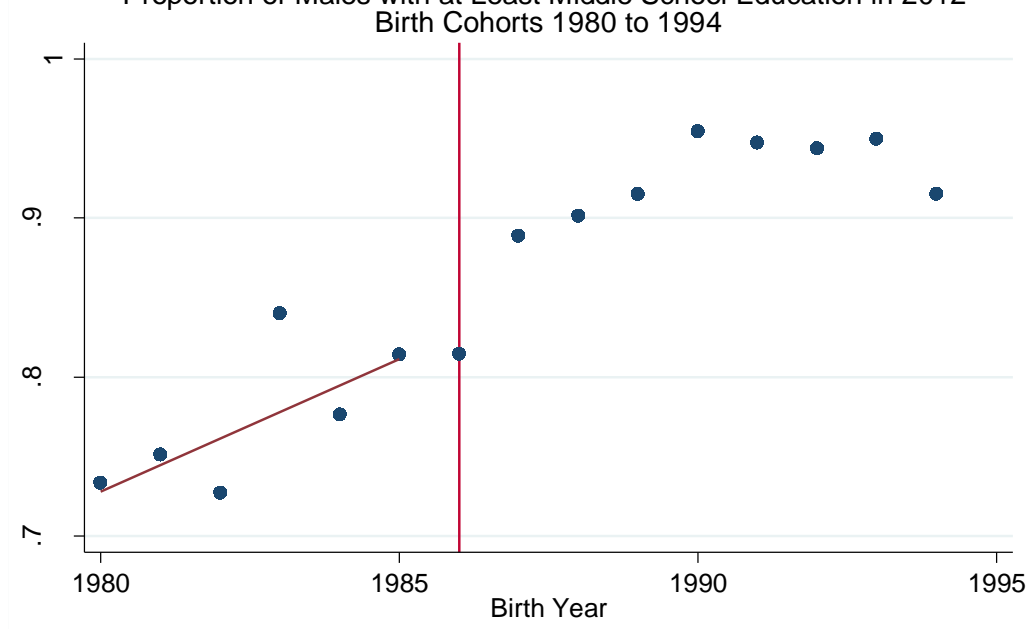


Figure 2B

Proportion of Males with at Least Middle School Education in 2012 Birth Cohorts 1960 to 1994

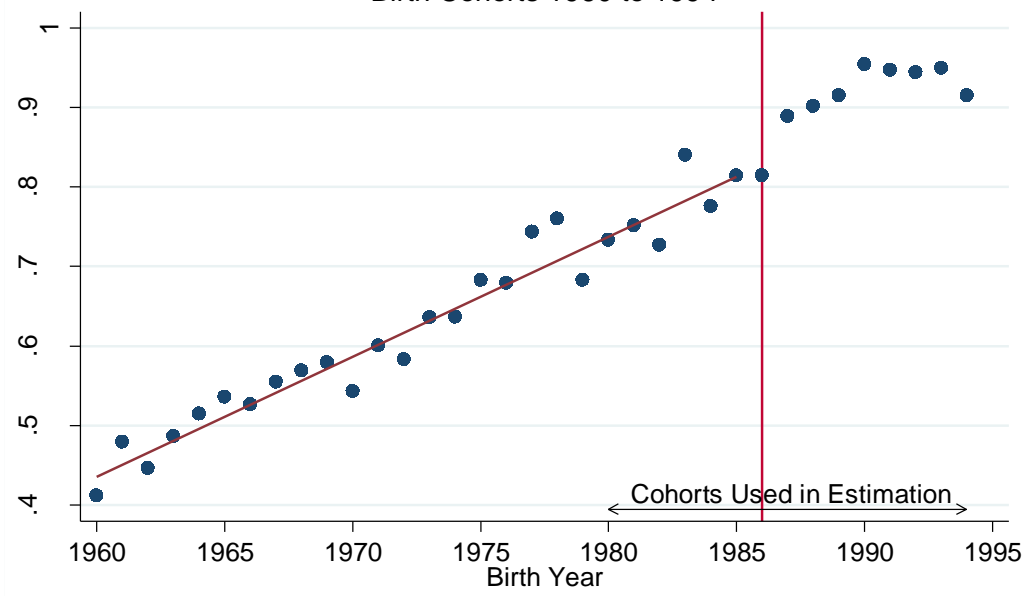

Figure 3A

Proportion of Females Who Wear a Head Cover in 2012

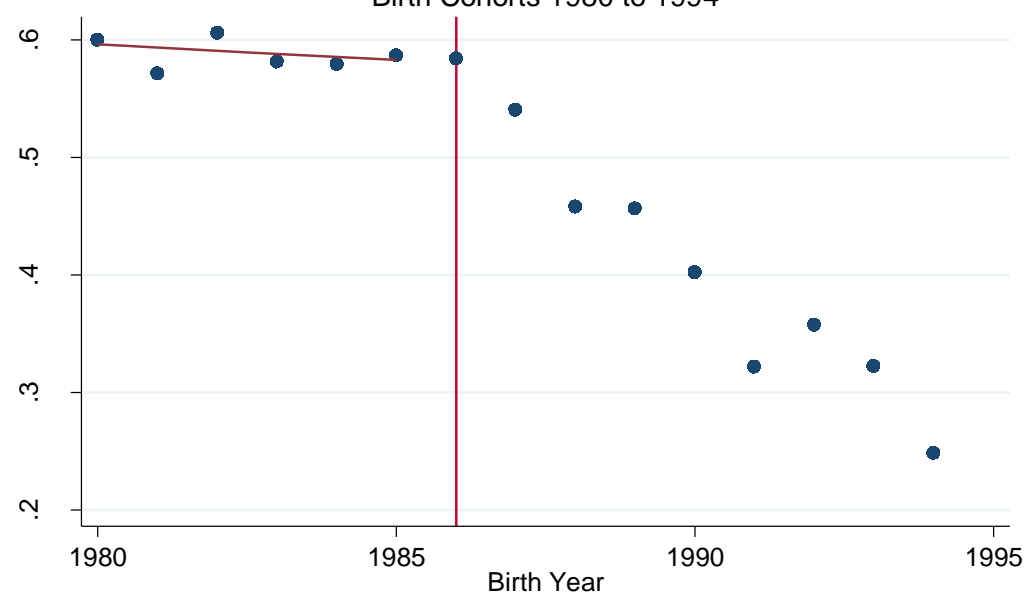

Figure 3B

Proportion of Females Who Wear a Head Cover in 2012 Birth Cohorts 1960 to 1994

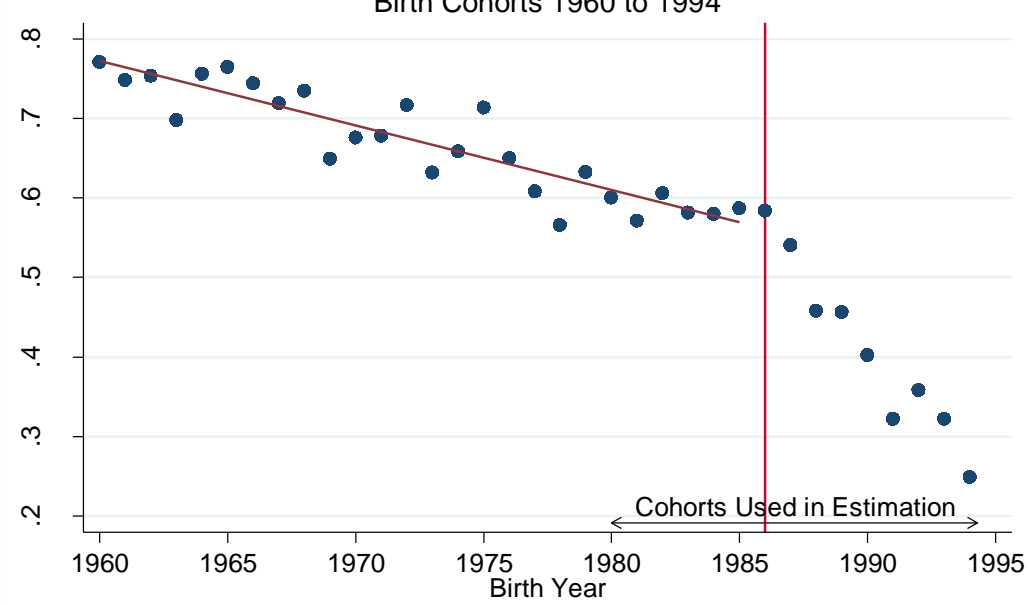


Figure 4

Proportion of Females Who Declare Themselves 'Modern' in 2012

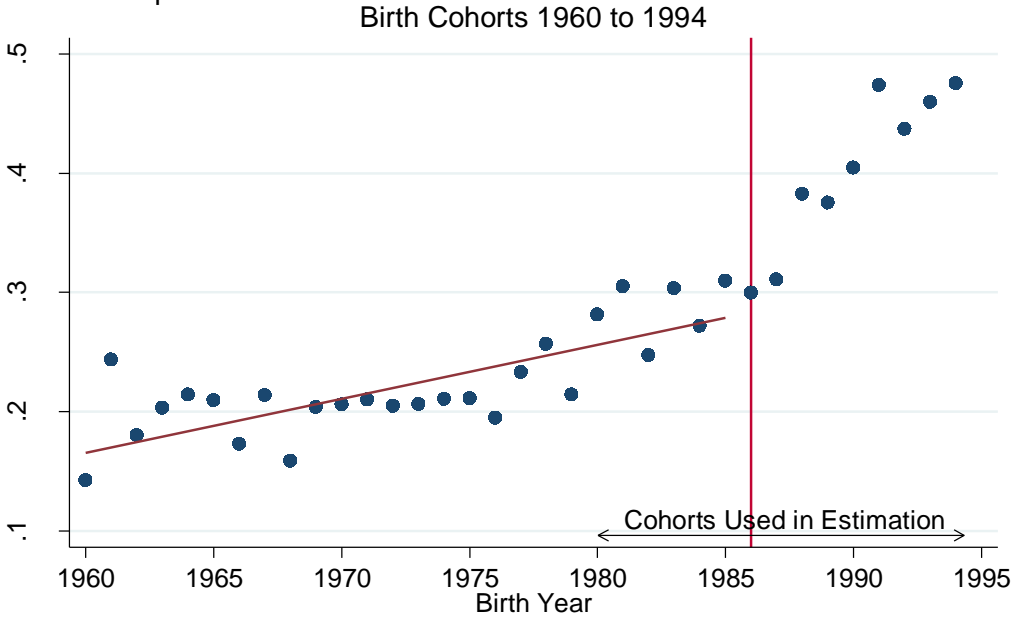

Figure 5

Proportion of Males Who Declare Themselves 'Modern' in 2012 Birth Cohorts 1960 to 1994

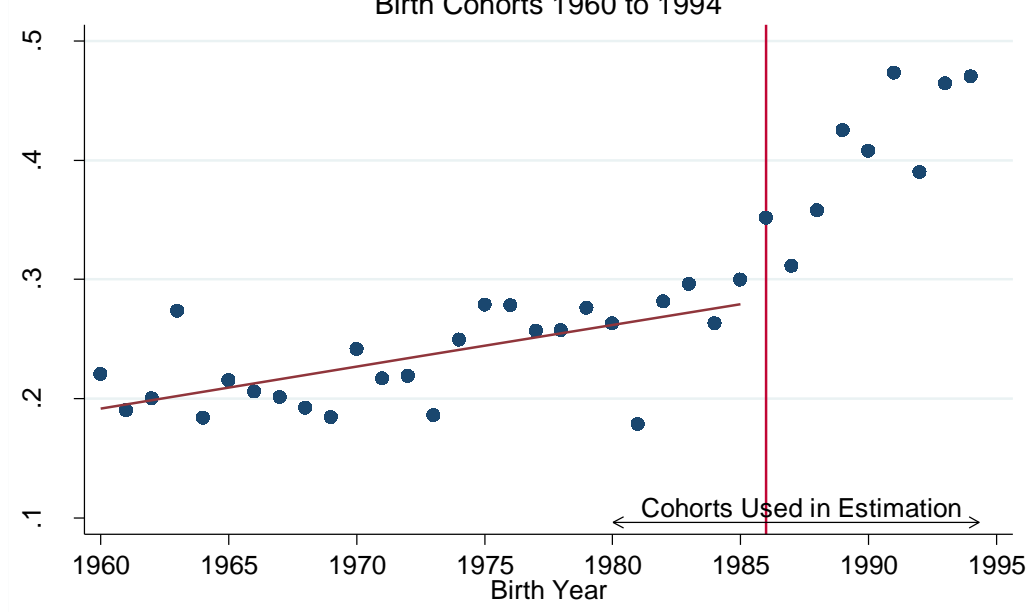

Figure 6

Proportion of Females Who Are Islamic Voters Now (in 2012) Birth Cohorts 1960 to 1994

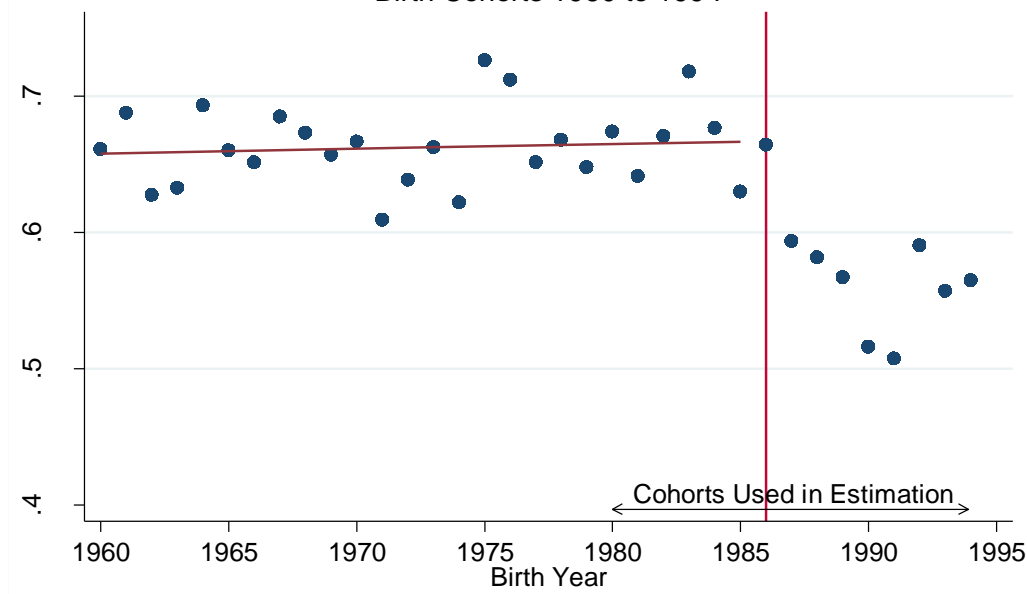


Figure 7

Proportion of Males Who Are Islamic Voters Now (in 2012) Birth Cohorts 1960 to 1994

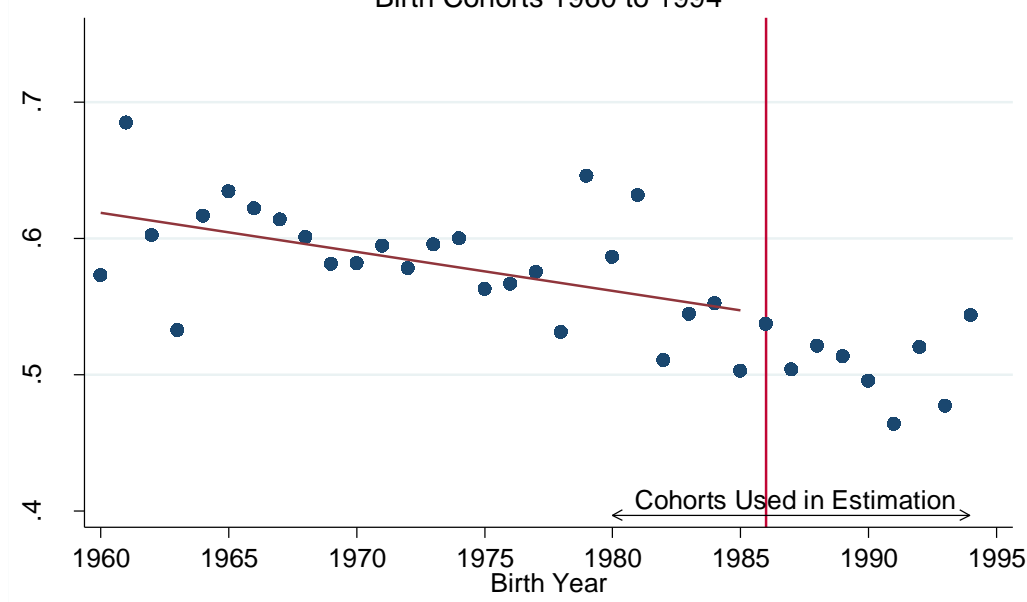

Figure 8A

Proportion of Females with at Least Middle School Education in 2012 Birth Cohorts 1960 to 1994 - Eastern Turkey

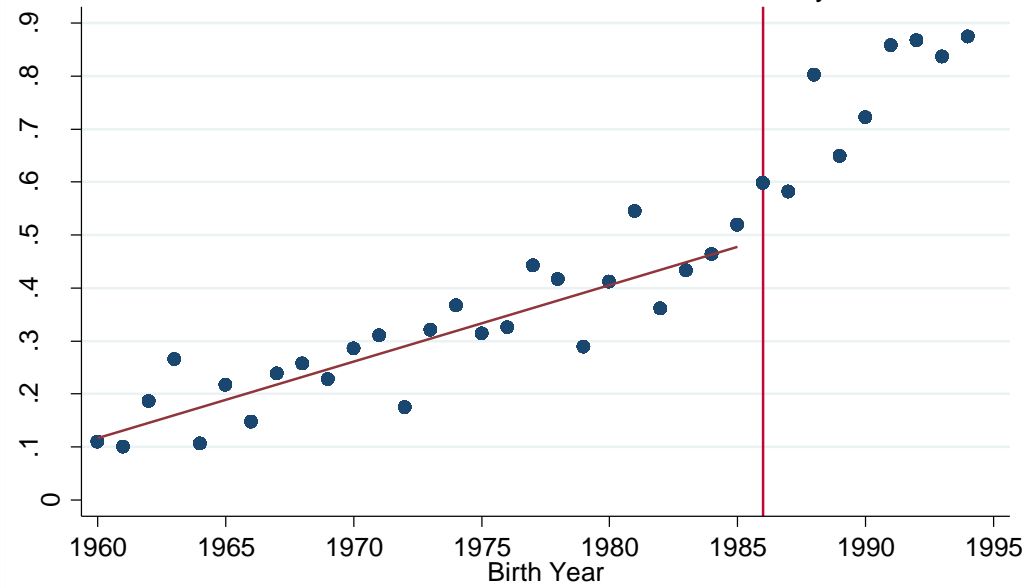

Figure 8B

Proportion of Females with at Least Middle School Education in 2012 Birth Cohorts 1960 to 1994 - Western Turkey

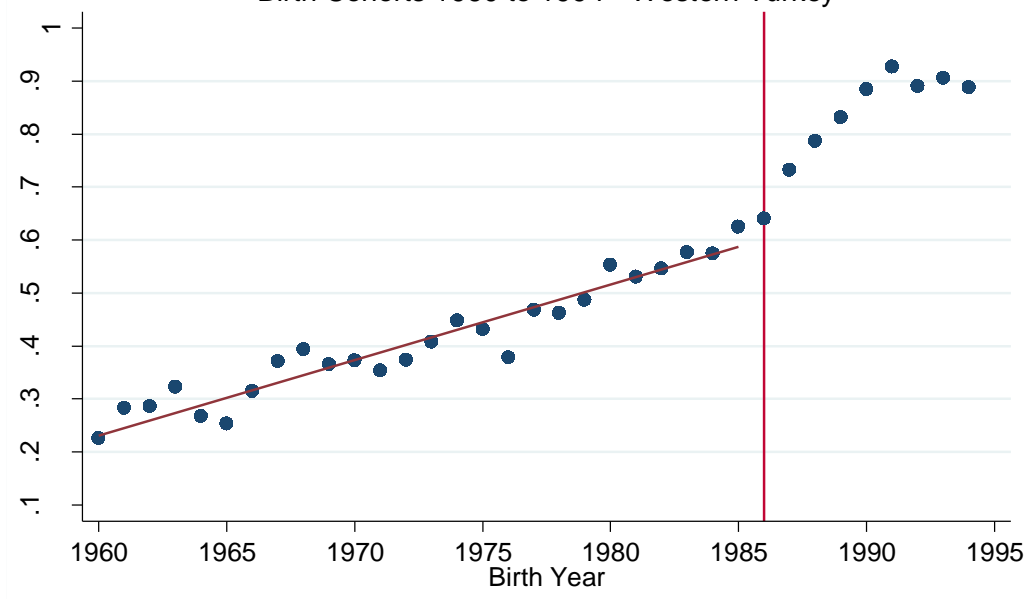


Figure 9A

Proportion of Males with at Least Middle School Education in 2012 Birth Cohorts 1960 to 1994 - Eastern Turkey

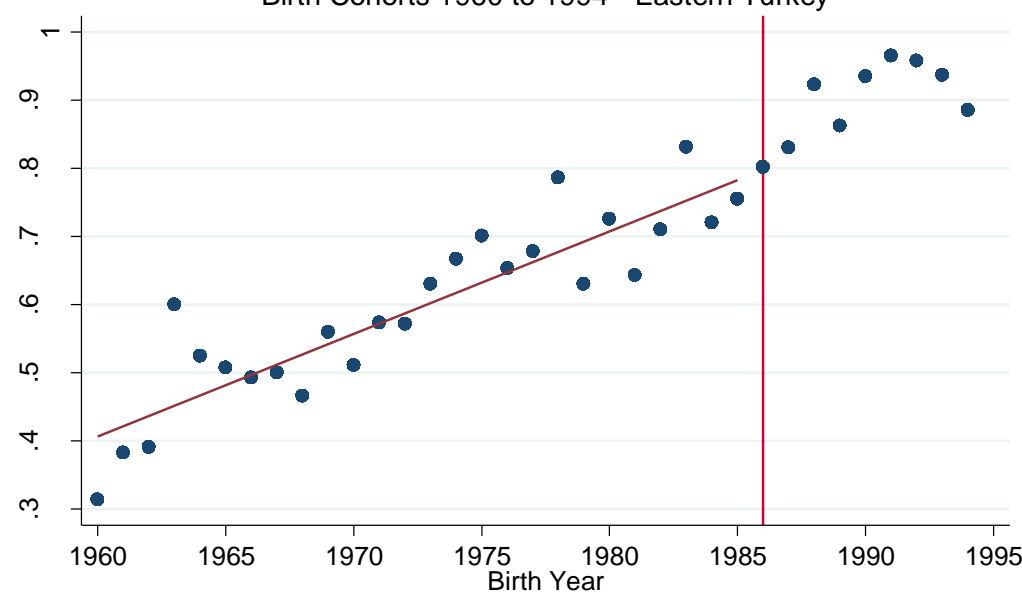

Figure 9B

Proportion of Males with at Least Middle School Education in 2012 Birth Cohorts 1960 to 1994 - Western Turkey

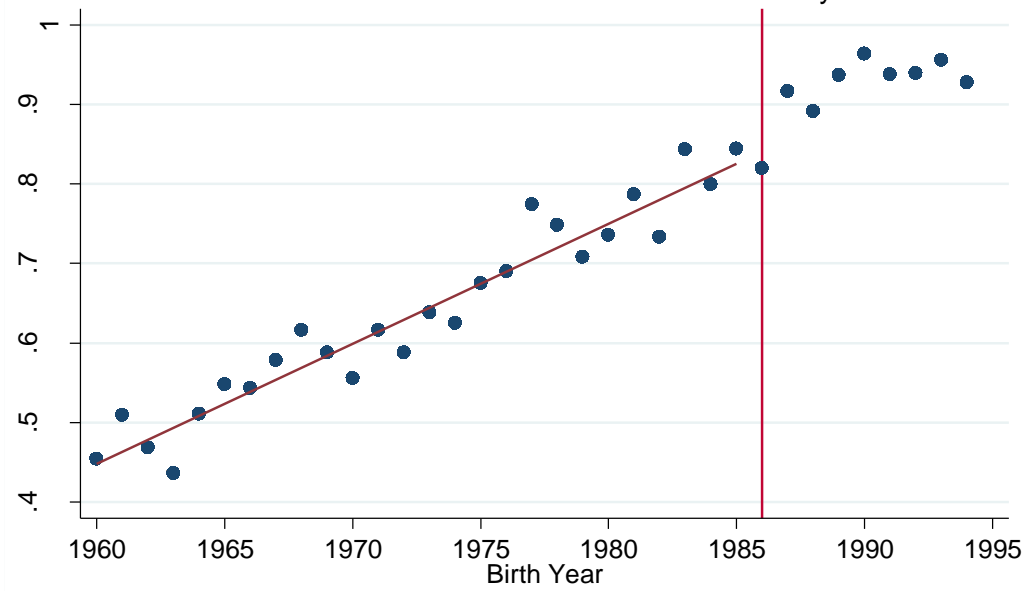

Figure 10

Proportion of Females Who Wear a Head Cover in 2012 Birth Cohorts 1960 to 1994 - Eastern Turkey

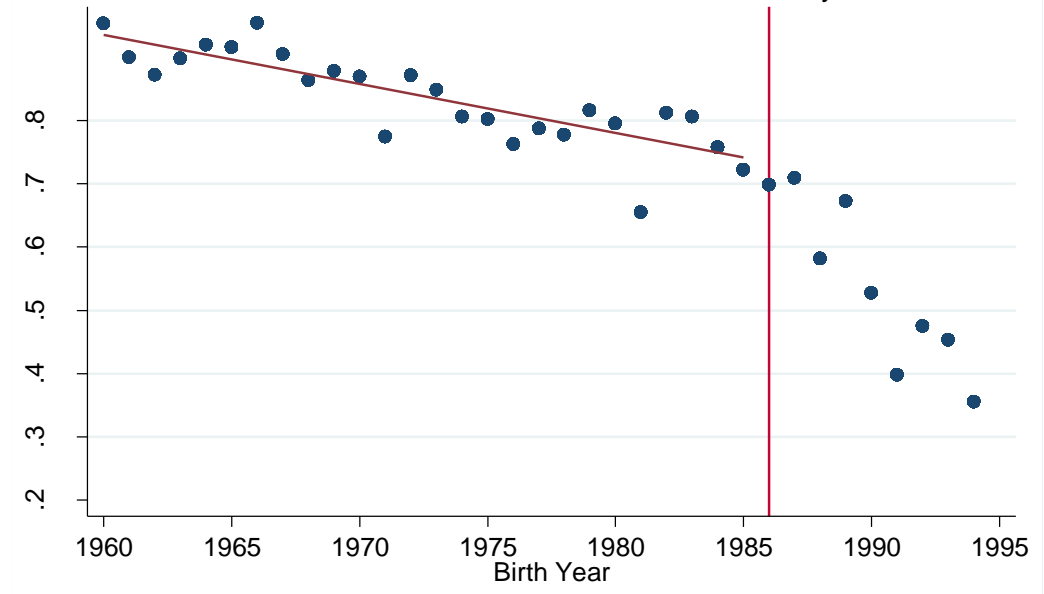


Figure 11

Proportion of Females Who Wear a Head Cover in 2012

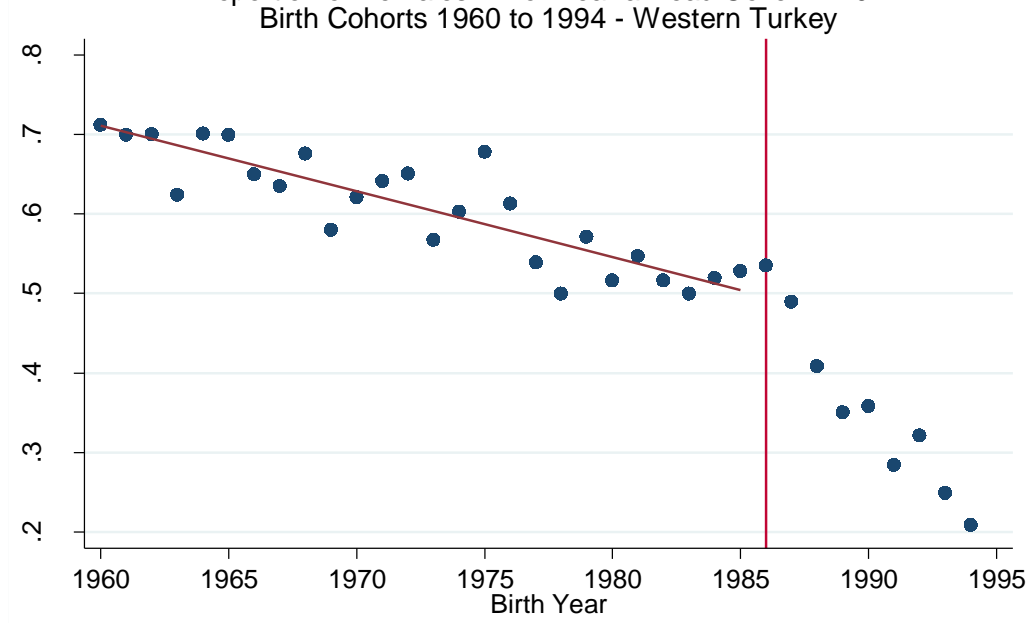

Figure 12

Proportion of Females Who Declares Themselves 'Modern' in 2012

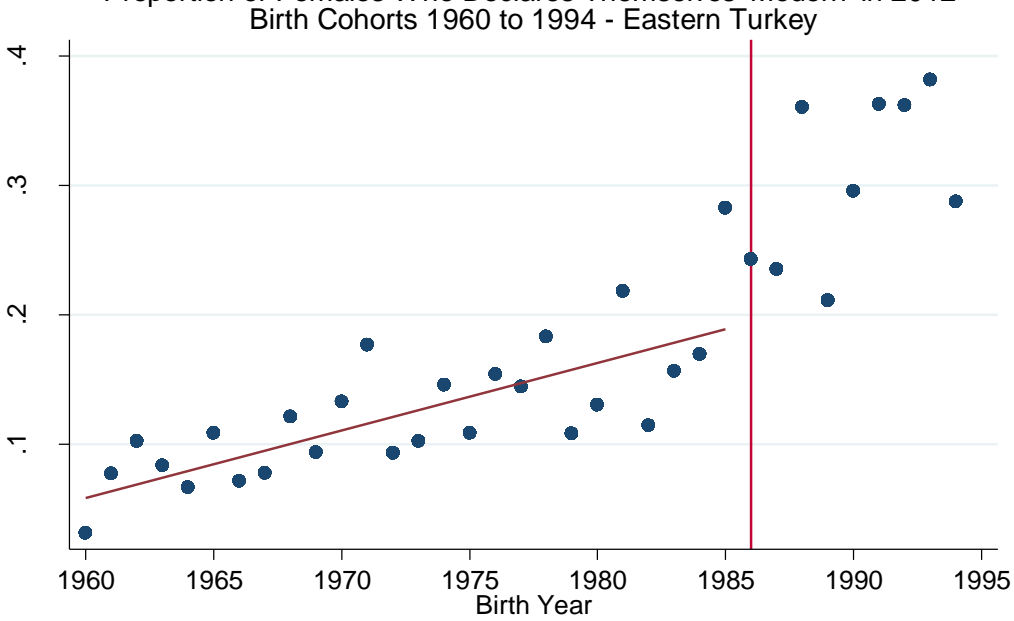

Figure 13

Proportion of Females Who Declares Themselves 'Modern' in 2012 Birth Cohorts 1960 to 1994 - Western Turkey

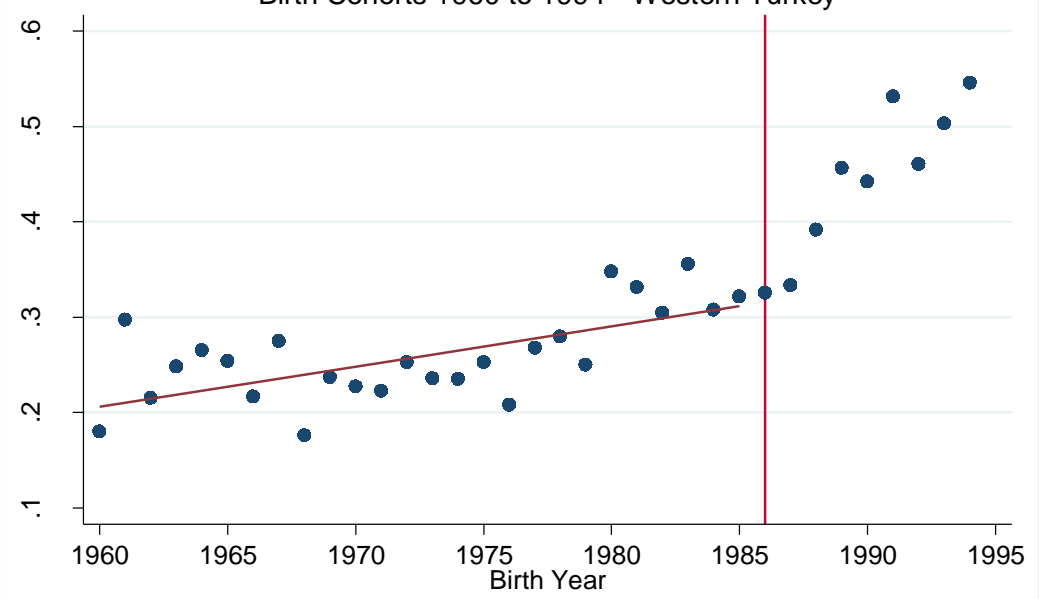


Figure 14

Proportion of Females Who Are Islamic Voters Now (in 2012)

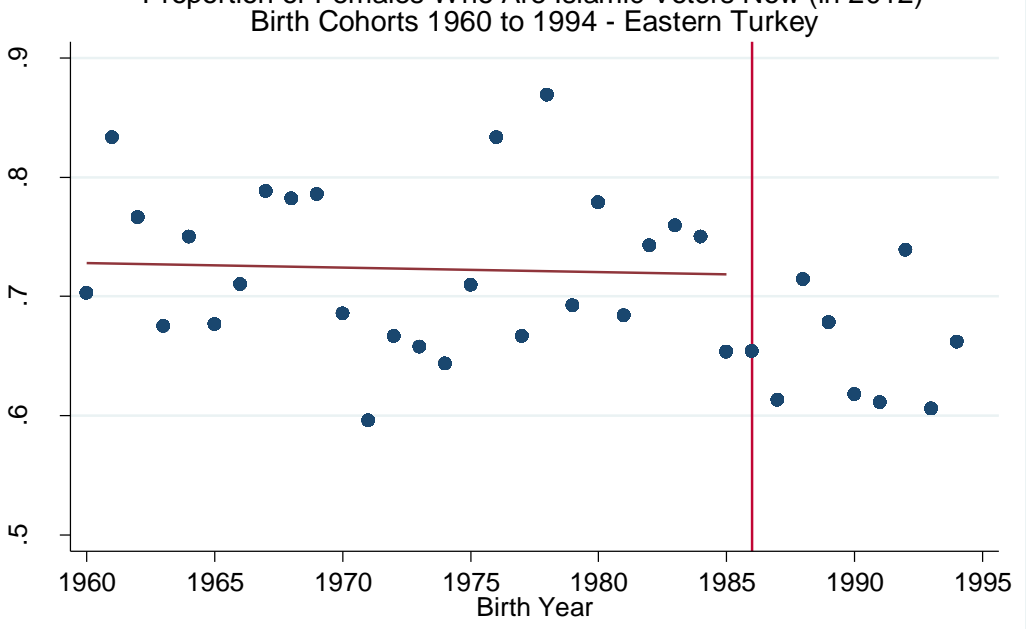

Figure 15

Proportion of Females Who Are Islamic Voters Now (in 2012)

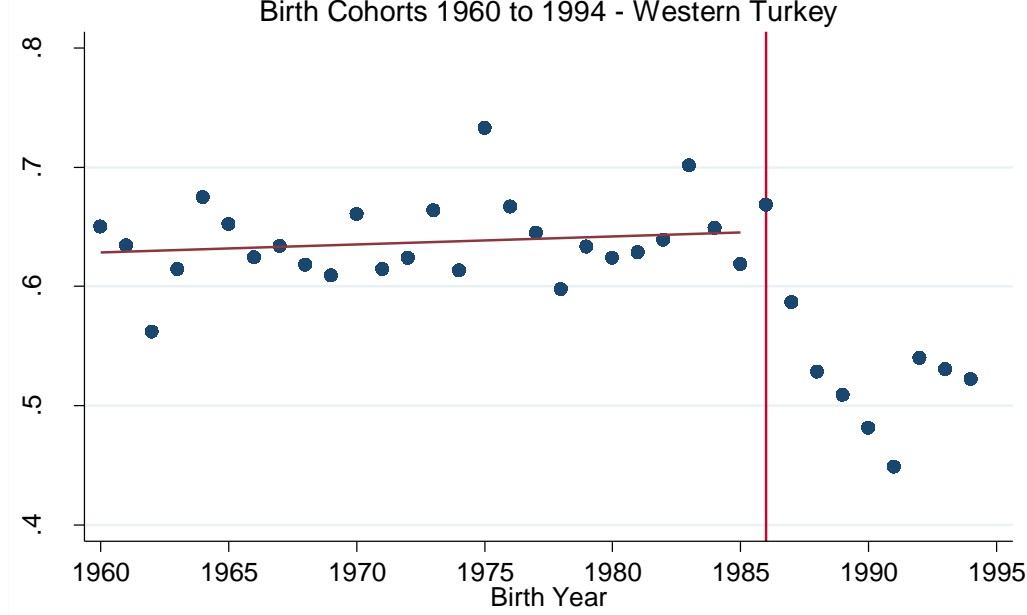


Table 1

Descriptive Statistics by Exposure to the 1997 Education Reform

\begin{tabular}{|c|c|c|c|c|c|c|}
\hline \multirow{2}{*}{ Variable } & \multirow{2}{*}{ Variable Definitions } & \multirow{2}{*}{ All } & \multicolumn{2}{|c|}{ Men } & \multicolumn{2}{|c|}{ Women } \\
\hline & & & Treatment & Control & Treatment & Control \\
\hline $\begin{array}{l}\text { Middle School } \\
\text { Diploma }\end{array}$ & $\begin{array}{l}=1 \text { if holds at least a middle school degree, } \\
=0 \text { otherwise }\end{array}$ & $\begin{array}{c}0.775 \\
(0.418)\end{array}$ & $\begin{array}{c}0.925 \\
(0.264)\end{array}$ & $\begin{array}{c}0.772 \\
(0.419)\end{array}$ & $\begin{array}{c}0.826 \\
(0.379)\end{array}$ & $\begin{array}{c}0.536 \\
(0.499)\end{array}$ \\
\hline Religious & $\begin{array}{l}=1 \text { if religious or devout, } \\
=0 \text { if believer or atheist }\end{array}$ & $\begin{array}{c}0.596 \\
(0.491)\end{array}$ & $\begin{array}{c}0.516 \\
(0.500)\end{array}$ & $\begin{array}{c}0.603 \\
(0.489)\end{array}$ & $\begin{array}{c}0.588 \\
(0.492)\end{array}$ & $\begin{array}{c}0.695 \\
(0.461)\end{array}$ \\
\hline Atheist & $\begin{array}{l}=1 \text { if atheist, } \\
=0 \text { if believer, religious, or devout }\end{array}$ & \begin{tabular}{|c|c|}
0.014 \\
$(0.119)$ \\
\end{tabular} & $\begin{array}{c}0.020 \\
(0.140)\end{array}$ & $\begin{array}{c}0.014 \\
(0.117)\end{array}$ & $\begin{array}{c}0.013 \\
(0.114) \\
\end{array}$ & $\begin{array}{c}0.009 \\
(0.096) \\
\end{array}$ \\
\hline Modern & $\begin{array}{l}=1 \text { if modern, } \\
=0 \text { if conventional or religious conservative }\end{array}$ & $\begin{array}{c}0.350 \\
(0.477) \\
\end{array}$ & $\begin{array}{c}0.414 \\
(0.493) \\
\end{array}$ & $\begin{array}{c}0.269 \\
(0.443)\end{array}$ & $\begin{array}{c}0.411 \\
(0.492) \\
\end{array}$ & $\begin{array}{c}0.283 \\
(0.451) \\
\end{array}$ \\
\hline Wears Head Cover & $\begin{array}{l}=1 \text { if wears headscarf/burka/turban, } \\
=0 \text { otherwise }\end{array}$ & $\begin{array}{c}0.489 \\
(0.500)\end{array}$ & $\begin{array}{l}- \\
-\end{array}$ & - & $\begin{array}{c}0.394 \\
(0.489)\end{array}$ & $\begin{array}{c}0.589 \\
(0.492)\end{array}$ \\
\hline Voted Islamic in 2011 & $\begin{array}{l}=1 \text { if voted for an Islamic political party in } \\
2011 \text { general elections, }=0 \text { otherwise }\end{array}$ & $\begin{array}{c}0.566 \\
(0.496) \\
\end{array}$ & $\begin{array}{c}0.503 \\
(0.500) \\
\end{array}$ & $\begin{array}{c}0.548 \\
(0.498)\end{array}$ & $\begin{array}{c}0.550 \\
(0.498) \\
\end{array}$ & $\begin{array}{c}0.649 \\
(0.477) \\
\end{array}$ \\
\hline Islamic Voter Now & $\begin{array}{l}=1 \text { if would vote for an Islamic political party } \\
\text { if general elections were held this Sunday } \\
(2012),=0 \text { otherwise }\end{array}$ & $\begin{array}{c}0.560 \\
(0.496)\end{array}$ & $\begin{array}{c}0.493 \\
(0.500)\end{array}$ & $\begin{array}{c}0.537 \\
(0.499)\end{array}$ & $\begin{array}{c}0.561 \\
(0.496)\end{array}$ & $\begin{array}{c}0.666 \\
(0.472)\end{array}$ \\
\hline Voter 2011 & $\begin{array}{l}=1 \text { if voted in the general elections } \\
\text { in } 2011,=0 \text { otherwise }\end{array}$ & $\begin{array}{c}0.899 \\
(0.301)\end{array}$ & $\begin{array}{c}0.836 \\
(0.371)\end{array}$ & $\begin{array}{c}0.941 \\
(0.235)\end{array}$ & $\begin{array}{c}0.875 \\
(0.331)\end{array}$ & $\begin{array}{c}0.945 \\
(0.228)\end{array}$ \\
\hline Voter Now & $\begin{array}{l}=1 \text { if would vote if general elections } \\
\text { were held this Sunday, }=0 \text { otherwise }\end{array}$ & $\begin{array}{c}0.932 \\
(0.252) \\
\end{array}$ & $\begin{array}{c}0.921 \\
(0.270) \\
\end{array}$ & $\begin{array}{c}0.936 \\
(0.246)\end{array}$ & $\begin{array}{c}0.930 \\
(0.256) \\
\end{array}$ & $\begin{array}{c}0.945 \\
(0.227) \\
\end{array}$ \\
\hline Sunni & $=1$ if Muslim Sunni, $=0$ otherwise & \begin{tabular}{|c|}
0.927 \\
$(0.260)$ \\
\end{tabular} & $\begin{array}{c}0.931 \\
(0.254) \\
\end{array}$ & $\begin{array}{c}0.928 \\
(0.258)\end{array}$ & $\begin{array}{c}0.923 \\
(0.267) \\
\end{array}$ & $\begin{array}{c}0.926 \\
(0.263) \\
\end{array}$ \\
\hline Alevite Shiite & $=1$ if Muslim Alevi, $=0$ otherwise & $\begin{array}{c}0.053 \\
(0.224) \\
\end{array}$ & $\begin{array}{c}0.048 \\
(0.214)\end{array}$ & $\begin{array}{c}0.055 \\
(0.227)\end{array}$ & $\begin{array}{c}0.055 \\
(0.229) \\
\end{array}$ & $\begin{array}{c}0.055 \\
(0.228)\end{array}$ \\
\hline $\begin{array}{l}\text { Kurdish or Zaza } \\
\text { Ethnicity }\end{array}$ & $=1$ if Kurdish or Zaza, $=0$ otherwise & $\begin{array}{c}0.143 \\
(0.350) \\
\end{array}$ & $\begin{array}{c}0.141 \\
(0.348) \\
\end{array}$ & $\begin{array}{c}0.141 \\
(0.348)\end{array}$ & $\begin{array}{c}0.153 \\
(0.361) \\
\end{array}$ & $\begin{array}{c}0.135 \\
(0.342) \\
\end{array}$ \\
\hline $\begin{array}{l}\text { Arabic or Other } \\
\text { Ethnicity }\end{array}$ & $\begin{array}{l}=1 \text { if ethnicity is not either Turkish } \\
\text { or Kurdish, }=0 \text { otherwise }\end{array}$ & $\begin{array}{c}0.042 \\
(0.202)\end{array}$ & $\begin{array}{c}0.042 \\
(0.201)\end{array}$ & $\begin{array}{c}0.040 \\
(0.197)\end{array}$ & $\begin{array}{c}0.045 \\
(0.208)\end{array}$ & $\begin{array}{c}0.042 \\
(0.199)\end{array}$ \\
\hline City & $=1$ if lives in a city, $=0$ otherwise & \begin{tabular}{|c|c|}
0.293 \\
$(0.455)$ \\
\end{tabular} & $\begin{array}{c}0.302 \\
(0.459) \\
\end{array}$ & $\begin{array}{c}0.277 \\
(0.448)\end{array}$ & $\begin{array}{c}0.312 \\
(0.464) \\
\end{array}$ & $\begin{array}{c}0.278 \\
(0.448)\end{array}$ \\
\hline Metropolitan Area & $\begin{array}{l}=1 \text { if lives in a metropolitan area, } \\
=0 \text { otherwise }\end{array}$ & $\begin{array}{c}0.505 \\
(0.500) \\
\end{array}$ & $\begin{array}{c}0.485 \\
(0.500) \\
\end{array}$ & $\begin{array}{c}0.503 \\
(0.500)\end{array}$ & $\begin{array}{c}0.498 \\
(0.500) \\
\end{array}$ & $\begin{array}{c}0.539 \\
(0.499) \\
\end{array}$ \\
\hline Migrant & $\begin{array}{l}=1 \text { if migrated out of the birth region, } \\
=0 \text { otherwise }\end{array}$ & $\begin{array}{c}0.267 \\
(0.442)\end{array}$ & $\begin{array}{c}0.226 \\
(0.418)\end{array}$ & $\begin{array}{c}0.286 \\
(0.452)\end{array}$ & $\begin{array}{c}0.253 \\
(0.435)\end{array}$ & $\begin{array}{c}0.315 \\
(0.464)\end{array}$ \\
\hline $\begin{array}{l}\text { Labor Force } \\
\text { Participation }\end{array}$ & $\begin{array}{l}=1 \text { if working, looking for work } \\
=0 \text { if housewife or not in the labor force }\end{array}$ & $\begin{array}{c}0.500 \\
(0.500) \\
\end{array}$ & $\begin{array}{c}0.548 \\
(0.497) \\
\end{array}$ & $\begin{array}{c}0.967 \\
(0.178)\end{array}$ & $\begin{array}{c}0.253 \\
(0.435) \\
\end{array}$ & $\begin{array}{c}0.275 \\
(0.447) \\
\end{array}$ \\
\hline No. of Observations & & 9,625 & 2,809 & 2,105 & 2,444 & 2,267 \\
\hline
\end{tabular}

The data pertain to 2012. Treatment group consists of those born in 1987-1994. The control group consists of those who were born in 1980-1985. Exposure to the Law is unclear for the 1986 cohort. 


\section{Table 2}

The Impact of Exposure to the Education Reform on the Propensity to Have at Least Eight Years of Education-- OLS regressions

\begin{tabular}{lccc}
\hline & $(1)$ & $(2)$ & $(3)$ \\
& All & Males & Females \\
\hline \multirow{2}{*}{ Exposure to the Law } & $0.102^{* * *}$ & $0.062^{* *}$ & $0.138^{* * *}$ \\
& $(0.022)$ & $(0.026)$ & $(0.035)$ \\
& {$[0.023]$} & {$[0.029]$} & \\
Male & $0.159^{* * *}$ & & \\
Age & $(0.019)$ & & \\
Age Squared & 0.004 & $0.040]$ & -0.039 \\
Sunni & $(0.020)$ & $(0.019)$ & $(0.029)$ \\
& -0.000 & $-0.001 * *$ & 0.000 \\
Alevite Shiite & $(0.000)$ & $(0.000)$ & $(0.001)$ \\
Kurdish or Zaza Ethnicity & -0.027 & -0.025 & -0.036 \\
& $(0.028)$ & $(0.026)$ & $(0.042)$ \\
Arabic or Other Ethnicity & $0.064 * *$ & -0.003 & $0.119 * *$ \\
& $(0.030)$ & $(0.034)$ & $(0.045)$ \\
& $-0.117^{* * *}$ & $-0.063 * *$ & $-0.175^{* * *}$ \\
N & $(0.029)$ & $(0.026)$ & $(0.039)$ \\
& $-0.038^{*}$ & -0.039 & -0.052 \\
& $(0.022)$ & $(0.028)$ & $(0.033)$ \\
& & & 4,694
\end{tabular}

The entries in parentheses are standard errors of the estimated coefficients, clustered by birth provinceage level. Twelve regions and five age groups yield 60 clusters. Standard errors, which are presented in brackets, are clustered by region of birth-exposure to the law, generating 24 clusters. A * indicates statistical level at the 10 percent level, ** stands for significance at the 5 percent level, *** indicates significance at the 1 percent level or better. Exposure to the Law $=1$ if the person was born between 1987 and 1994, it is zero if the year of birth is between 1980 and 1985. The 1986 cohort is excluded as exposure to the law depends on the exact day of birth for this cohort. If Kurdish or Zaza Ethnicity $=0$ and Arabic and Other Ethnicity $=0$, the individual is a Turk. Regressions include region fixed-effects and monthly dummies for the survey month, as well as dummies for region of birth. 


\section{Table 3}

The Impact of Education on Religiosity, the Propensity to Cast a Vote, and the Propensity to Vote for an Islamic Party-Instrumental Variables Regressions Whole Sample

\begin{tabular}{|c|c|c|c|c|c|c|c|c|}
\hline VARIABLES & $\begin{array}{c}\text { (1) } \\
\text { Religious }\end{array}$ & $\begin{array}{c}\text { (2) } \\
\text { Atheist }\end{array}$ & $\begin{array}{c}\text { (3) } \\
\text { Modern }\end{array}$ & $\begin{array}{c}(4) \\
\text { Voter } \\
2011\end{array}$ & $\begin{array}{c}(5) \\
\text { Voter } \\
\text { Now }\end{array}$ & $\begin{array}{c}(6) \\
\text { Voted } \\
\text { Islamic in } \\
2011 \\
\end{array}$ & $\begin{array}{c}(7) \\
\text { Islamic } \\
\text { Voter } \\
\text { Now } \\
\end{array}$ & $\begin{array}{c}(8) \\
\text { Never } \\
\text { Vote } \\
\text { Islamic } \\
\end{array}$ \\
\hline Midd & $\begin{array}{c}-0.398 * * \\
(0.201) \\
{[0.176]}\end{array}$ & $\begin{array}{l}0.082 * \\
(0.042) \\
{[0.045]}\end{array}$ & $\begin{array}{l}0.301 * \\
(0.169) \\
{[0.167]}\end{array}$ & $\begin{array}{l}-0.149 \\
(0.145) \\
{[0.147]}\end{array}$ & $\begin{array}{c}0.005 \\
(0.095) \\
{[0.102]}\end{array}$ & $\begin{array}{c}-0.330 * \\
(0.181) \\
{[0.203]}\end{array}$ & $\begin{array}{c}-0.419 * * \\
(0.175) \\
{[0.175]}\end{array}$ & $\begin{array}{c}0.453 * * \\
(0.219) \\
{[0.254]}\end{array}$ \\
\hline Age & $\begin{array}{l}-0.011 \\
(0.018)\end{array}$ & $\begin{array}{c}0.001 \\
(0.003)\end{array}$ & $\begin{array}{c}-0.049 * * * \\
(0.013)\end{array}$ & $\begin{array}{c}0.074 * * * \\
(0.013)\end{array}$ & $\begin{array}{c}0.019 * * \\
(0.008)\end{array}$ & $\begin{array}{l}-0.013 \\
(0.020)\end{array}$ & $\begin{array}{c}-0.035^{* *} \\
(0.016)\end{array}$ & $\begin{array}{c}0.018 \\
(0.024)\end{array}$ \\
\hline Age & $\begin{array}{c}0.000 \\
(0.000)\end{array}$ & $\begin{array}{c}0.000 \\
(0.000)\end{array}$ & $\begin{array}{c}0.001 * * * \\
(0.000)\end{array}$ & $\begin{array}{c}-0.001 * * * \\
(0.000)\end{array}$ & $\begin{array}{c}-0.000^{*} \\
(0.000)\end{array}$ & $\begin{array}{c}0.000 \\
(0.000)\end{array}$ & $\begin{array}{l}0.001 * \\
(0.000)\end{array}$ & $\begin{array}{l}-0.000 \\
(0.000)\end{array}$ \\
\hline Male & $\begin{array}{l}-0.016 \\
(0.035)\end{array}$ & $\begin{array}{l}-0.007 \\
(0.007)\end{array}$ & $\begin{array}{c}-0.054^{*} \\
(0.030)\end{array}$ & $\begin{array}{c}0.004 \\
(0.026)\end{array}$ & $\begin{array}{l}-0.010 \\
(0.015)\end{array}$ & $\begin{array}{l}-0.013 \\
(0.034)\end{array}$ & $\begin{array}{l}-0.022 \\
(0.031)\end{array}$ & $\begin{array}{c}0.001 \\
(0.040)\end{array}$ \\
\hline Sunni & $\begin{array}{l}-0.005 \\
(0.033)\end{array}$ & $\begin{array}{c}-0.029 * * \\
(0.014)\end{array}$ & $\begin{array}{c}-0.150 * * * \\
(0.030)\end{array}$ & $\begin{array}{c}0.017 \\
(0.032)\end{array}$ & $\begin{array}{c}0.028 \\
(0.018)\end{array}$ & $\begin{array}{c}0.158 * * * \\
(0.050)\end{array}$ & $\begin{array}{c}0.094^{* *} \\
(0.043)\end{array}$ & $\begin{array}{c}-0.126^{* *} \\
(0.060)\end{array}$ \\
\hline Alevite Shiite & $\begin{array}{c}-0.356^{* * * *} \\
(0.046)\end{array}$ & $\begin{array}{c}0.038^{* *} \\
(0.017)\end{array}$ & $\begin{array}{r}0.177 \\
(0.03\end{array}$ & $\begin{array}{c}0.045 \\
(0.039)\end{array}$ & $\begin{array}{c}0.010 \\
(0.024)\end{array}$ & $\begin{array}{c}-0.334 * * * \\
(0.061)\end{array}$ & $\begin{array}{c}-0.391 * * * \\
(0.053)\end{array}$ & $\begin{array}{c}0.398 * * * \\
(0.071)\end{array}$ \\
\hline Kurdish or Zaza Ethnicity & $\begin{array}{c}0.016 \\
(0.030)\end{array}$ & $\begin{array}{c}0.023 * * * \\
(0.008)\end{array}$ & $\begin{array}{c}-0.040^{*} \\
(0.023)\end{array}$ & $\begin{array}{l}-0.024 \\
(0.021)\end{array}$ & $\begin{array}{l}-0.017 \\
(0.014)\end{array}$ & $\begin{array}{c}-0.207 * * * \\
(0.044)\end{array}$ & $\begin{array}{c}-0.199 * * * \\
(0.039)\end{array}$ & $\begin{array}{c}0.212 * * * \\
(0.043)\end{array}$ \\
\hline Arabic or Other Ethnicity & $\begin{array}{c}0.070 * * \\
(0.030)\end{array}$ & $\begin{array}{c}0.024 * * \\
(0.010)\end{array}$ & $\begin{array}{l}-0.025 \\
(0.031)\end{array}$ & $\begin{array}{l}-0.018 \\
(0.019)\end{array}$ & $\begin{array}{l}-0.021 \\
(0.014)\end{array}$ & $\begin{array}{c}0.063 * * \\
(0.029)\end{array}$ & $\begin{array}{c}0.049 \\
(0.032)\end{array}$ & $\begin{array}{c}-0.073^{* *} \\
(0.035)\end{array}$ \\
\hline $\begin{array}{l}\mathrm{N} \\
\text { 1st Stage F-test } \\
\text { P-value }\end{array}$ & $\begin{array}{c}9,590 \\
21.80 \\
0.00\end{array}$ & $\begin{array}{c}21.80 \\
0.00\end{array}$ & $\begin{array}{c}21.43 \\
0.00\end{array}$ & $\begin{array}{c}22.82 \\
0.00\end{array}$ & $\begin{array}{c}24.11 \\
0.00\end{array}$ & $\begin{array}{c}6,923 \\
20.46 \\
0.00\end{array}$ & $\begin{array}{c}7,214 \\
24.46 \\
0.00\end{array}$ & $\begin{array}{c}5,834 \\
15.86 \\
0.00\end{array}$ \\
\hline
\end{tabular}

The entries in parentheses are standard errors of the estimated coefficients, clustered by birth province-age level. Twelve regions and five age groups yield 60 clusters. Standard errors, which are presented in brackets, are clustered by region of birth-exposure to the law, generating 24 clusters. A * indicates statistical level at the 10 percent level, ** stands for significance at the 5 percent level, $* * *$ indicates significance at the 1 percent level or better. Exposure to the Law $=1$ if the person was born between 1987 and 1994, it is zero if the year of birth is between 1980 and 1985. The 1986 cohort is excluded as exposure to the law depends on the exact day of birth for this cohort. If Kurdish or Zaza Ethnicity $=0$ and Arabic and Other Ethnicity $=0$, the individual is a Turk. Regressions include region fixed-effects and monthly dummies for the survey month, as well as dummies for region of birth. 
Table 4

The Joint Distribution of Voters for an Islamic Party in 2011 and Now (in 2012)

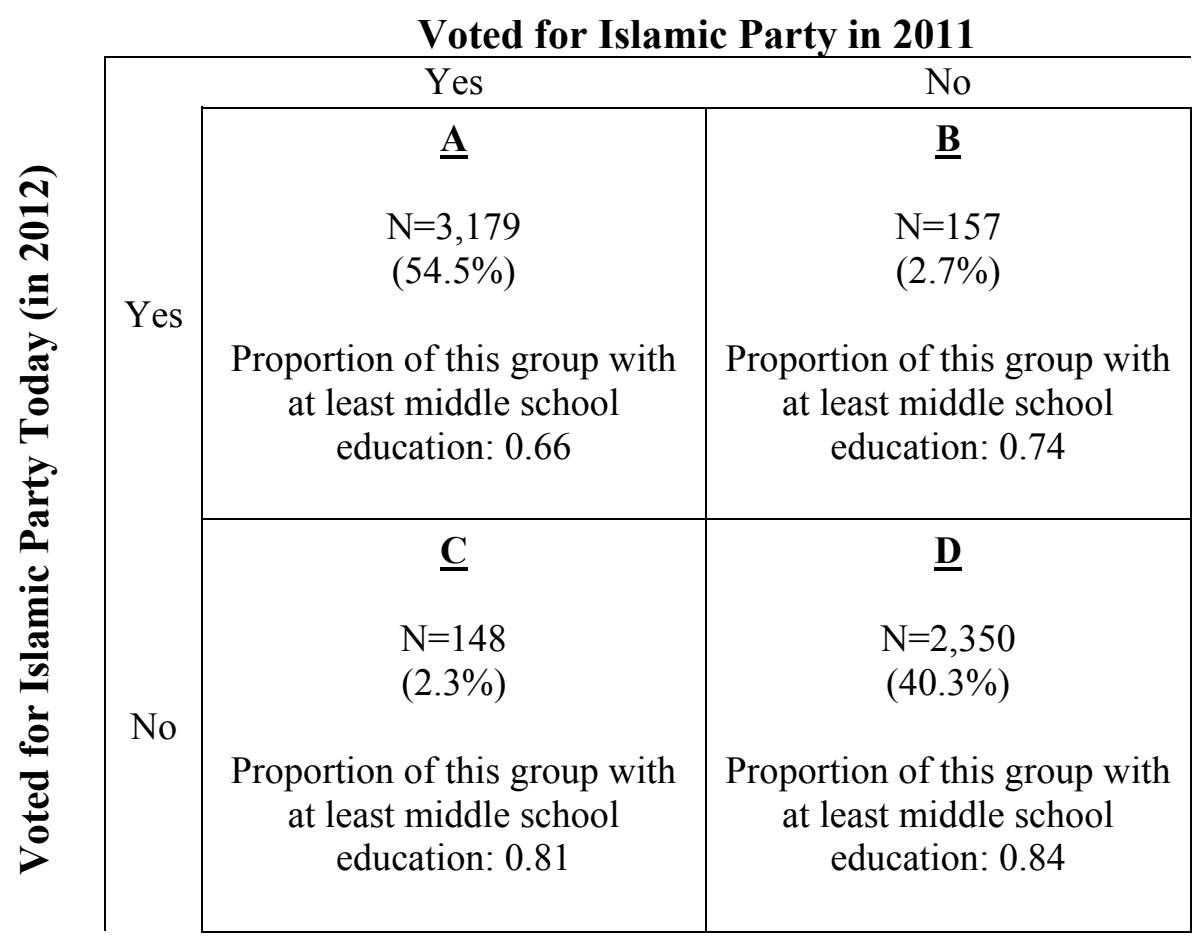


Table 5

The Impact of Education on Religiosity, the Propensity to Cast a Vote, and the Propensity to Vote for an Islamic Party-Instrumental Variables Regressions

Females

\begin{tabular}{|c|c|c|c|c|c|c|c|c|c|}
\hline VARIABLES & $\begin{array}{c}(1) \\
\text { Religious }\end{array}$ & $\begin{array}{c}\text { (2) } \\
\text { Atheist }\end{array}$ & $\begin{array}{c}\text { (3) } \\
\text { Modern }\end{array}$ & $\begin{array}{c}(4) \\
\text { Wears } \\
\text { Head } \\
\text { Cover } \\
\end{array}$ & $\begin{array}{c}(5) \\
\text { Voter } \\
2011\end{array}$ & $\begin{array}{c}(6) \\
\text { Voter } \\
\text { Now }\end{array}$ & $\begin{array}{c}(7) \\
\text { Voted } \\
\text { Islamic in } \\
2011 \\
\end{array}$ & $\begin{array}{c}(8) \\
\text { Islamic } \\
\text { Voter } \\
\text { Now } \\
\end{array}$ & $\begin{array}{c}(9) \\
\text { Never } \\
\text { Vote } \\
\text { Islamic } \\
\end{array}$ \\
\hline Middle School Diploma & $\begin{array}{c}-0.298 * * \\
(0.152) \\
{[0.145]}\end{array}$ & $\begin{array}{c}0.072 \\
(0.049) \\
{[0.043]}\end{array}$ & $\begin{array}{c}0.293 * * \\
(0.148) \\
{[0.125]}\end{array}$ & $\begin{array}{c}-0.399 * * \\
(0.203) \\
{[0.225]}\end{array}$ & $\begin{array}{c}0.044 \\
(0.119) \\
{[0.112]}\end{array}$ & $\begin{array}{c}0.046 \\
(0.084) \\
{[0.095]}\end{array}$ & $\begin{array}{c}-0.518 * *- \\
(0.224) \\
{[0.242]}\end{array}$ & $\begin{array}{c}-0.537 * * * \\
(0.177) \\
{[0.209]}\end{array}$ & $\begin{array}{c}0.607 * * \\
(0.281) \\
{[0.325]}\end{array}$ \\
\hline Age & $\begin{array}{c}0.013 \\
(0.018)\end{array}$ & $\begin{array}{c}0.007 \\
(0.005)\end{array}$ & $\begin{array}{c}-0.050 * * * \\
(0.016)\end{array}$ & $\begin{array}{c}0.103 * * * \\
(0.018)\end{array}$ & $\begin{array}{c}0.089 * * * \\
(0.021)\end{array}$ & $\begin{array}{c}0.033 * * * \\
(0.009)\end{array}$ & $\begin{array}{c}-0.021 \\
(0.041)\end{array}$ & $\begin{array}{l}-0.026 \\
(0.023)\end{array}$ & $\begin{array}{c}0.034 \\
(0.046)\end{array}$ \\
\hline Age Squared & $\begin{array}{l}-0.000 \\
(0.000)\end{array}$ & $\begin{array}{l}-0.000 \\
(0.000)\end{array}$ & $\begin{array}{c}0.001 * * * \\
(0.000)\end{array}$ & $\begin{array}{c}-0.002 * * * \\
(0.000)\end{array}$ & $\begin{array}{c}-0.001 * * * \\
(0.000)\end{array}$ & $\begin{array}{c}-0.001 * * * \\
(0.000)\end{array}$ & $\begin{array}{c}0.000 \\
(0.001)\end{array}$ & $\begin{array}{c}0.000 \\
(0.000)\end{array}$ & $\begin{array}{c}-0.000 \\
(0.001)\end{array}$ \\
\hline Sunni & $\begin{array}{c}0.022 \\
(0.044)\end{array}$ & $\begin{array}{l}-0.034 \\
(0.021)\end{array}$ & $\begin{array}{c}-0.093^{*} \\
(0.052)\end{array}$ & $\begin{array}{c}0.145^{* * *} \\
(0.047)\end{array}$ & $\begin{array}{l}-0.011 \\
(0.030)\end{array}$ & $\begin{array}{c}0.000 \\
(0.023)\end{array}$ & $\begin{array}{l}0.119^{*} \\
(0.065)\end{array}$ & $\begin{array}{c}0.086 \\
(0.057)\end{array}$ & $\begin{array}{c}-0.079 \\
(0.067)\end{array}$ \\
\hline Alevite Shiite & $\begin{array}{c}-0.343 * * * \\
(0.055)\end{array}$ & $\begin{array}{c}0.034 \\
(0.024)\end{array}$ & $\begin{array}{c}0.232 * * * \\
(0.058)\end{array}$ & $\begin{array}{c}-0.220 * * * \\
(0.056)\end{array}$ & $\begin{array}{l}-0.031 \\
(0.044)\end{array}$ & $\begin{array}{l}-0.037 \\
(0.028)\end{array}$ & $\begin{array}{c}-0.327 * * * \\
(0.071)\end{array}$ & $\begin{array}{c}-0.416^{* * *} \\
(0.069)\end{array}$ & $\begin{array}{c}0.428 * * * \\
(0.089)\end{array}$ \\
\hline Kurdish or Zaza Ethnicity & $\begin{array}{c}0.031 \\
(0.034)\end{array}$ & $\begin{array}{c}0.028 * * \\
(0.011)\end{array}$ & $\begin{array}{l}-0.043 \\
(0.032)\end{array}$ & $\begin{array}{l}0.074 * \\
(0.041)\end{array}$ & $\begin{array}{l}-0.000 \\
(0.024)\end{array}$ & $\begin{array}{l}-0.006 \\
(0.018)\end{array}$ & $\begin{array}{c}-0.234 * * * \\
(0.053)\end{array}$ & $\begin{array}{c}-0.205^{* * *} \\
(0.052)\end{array}$ & $\begin{array}{c}0.239 * * * \\
(0.060)\end{array}$ \\
\hline Arabic or Other Ethnicity & $\begin{array}{c}0.044 \\
(0.036)\end{array}$ & $\begin{array}{c}0.039 * * * \\
(0.013)\end{array}$ & $\begin{array}{l}-0.014 \\
(0.037)\end{array}$ & $\begin{array}{c}0.026 \\
(0.035)\end{array}$ & $\begin{array}{l}-0.016 \\
(0.023)\end{array}$ & $\begin{array}{c}0.025 \\
(0.024)\end{array}$ & $\begin{array}{c}0.056 \\
(0.041)\end{array}$ & $\begin{array}{c}0.056 \\
(0.040)\end{array}$ & $\begin{array}{c}-0.073 \\
(0.048)\end{array}$ \\
\hline $\mathbf{N}$ & 4,694 & 4,694 & 4,641 & 4,659 & 4,135 & 4,612 & 3,527 & 3,489 & 2,958 \\
\hline 1 st $S$ & 15.80 & 15.80 & 15.66 & 15.59 & 14.38 & 16.43 & 13.16 & 16.86 & 9.66 \\
\hline $\mathrm{P}$-value & 0.00 & 0.00 & 0.00 & 0.00 & 0.00 & 0.00 & 0.00 & 0.00 & 0.00 \\
\hline
\end{tabular}

The entries in parentheses are standard errors of the estimated coefficients, clustered by birth province-age level. Twelve regions and five age groups yield 60 clusters Standard errors, which are presented in brackets, are clustered by region of birth-exposure to the law, generating 24 clusters. A* indicates statistical level at the 10 percent level, ** stands for significance at the 5 percent level, *** indicates significance at the 1 percent level or better. Exposure to the Law $=1$ if the person was born between 1987 and 1994, it is zero if the year of birth is between 1980 and 1985. The 1986 cohort is excluded as exposure to the law depends on the exact day of birth for this cohort. If Kurdish or Zaza Ethnicity $=0$ and Arabic and Other Ethnicity $=0$, the individual is a Turk. Regressions include region fixed-effects and monthly dummies for the survey month, as well as dummies for region of birth. 
Table 6

The Impact of Education on Religiosity, the Propensity to Cast a Vote, and the Propensity to Vote for an Islamic Party-Instrumental Variables Regressions Males

\begin{tabular}{|c|c|c|c|c|c|c|c|c|}
\hline VARIABLES & $\begin{array}{c}(1) \\
\text { Religious }\end{array}$ & $\begin{array}{c}\text { (2) } \\
\text { Atheist }\end{array}$ & $\begin{array}{c}(3) \\
\text { Modern }\end{array}$ & $\begin{array}{c}(4) \\
\text { Voter } \\
2011\end{array}$ & $\begin{array}{c}(5) \\
\text { Voter } \\
\text { Now }\end{array}$ & $\begin{array}{c}(6) \\
\text { Voted } \\
\text { Islamic in } \\
2011 \\
\end{array}$ & $\begin{array}{c}(7) \\
\text { Islamic } \\
\text { Voter } \\
\text { Now } \\
\end{array}$ & $\begin{array}{c}(8) \\
\text { Never } \\
\text { Vote } \\
\text { Islamic } \\
\end{array}$ \\
\hline Middle School Diploma & $\begin{array}{l}-0.549 \\
(0.506) \\
{[0.486]}\end{array}$ & $\begin{array}{c}0.130 \\
(0.101) \\
{[0.105]}\end{array}$ & $\begin{array}{c}0.252 \\
(0.390) \\
{[0.456]}\end{array}$ & $\begin{array}{l}-0.551 \\
(0.371) \\
{[0.383]}\end{array}$ & $\begin{array}{l}-0.085 \\
(0.243) \\
{[0.236]}\end{array}$ & $\begin{array}{c}0.077 \\
(0.397) \\
{[0.424]}\end{array}$ & $\begin{array}{l}-0.112 \\
(0.412) \\
{[0.400]}\end{array}$ & $\begin{array}{c}0.150 \\
(0.338) \\
{[0.336]}\end{array}$ \\
\hline Age & $\begin{array}{l}-0.028 \\
(0.034)\end{array}$ & $\begin{array}{l}-0.006 \\
(0.005)\end{array}$ & $\begin{array}{l}-0.037 \\
(0.025)\end{array}$ & $\begin{array}{c}0.084 * * * \\
(0.020)\end{array}$ & $\begin{array}{c}0.016 \\
(0.013)\end{array}$ & $\begin{array}{l}-0.031 \\
(0.028)\end{array}$ & $\begin{array}{c}-0.064 * * \\
(0.027)\end{array}$ & $\begin{array}{c}0.028 \\
(0.027)\end{array}$ \\
\hline Age Squared & $\begin{array}{c}0.001 \\
(0.001)\end{array}$ & $\begin{array}{c}0.000 \\
(0.000)\end{array}$ & $\begin{array}{c}0.000 \\
(0.001)\end{array}$ & $\begin{array}{c}-0.002 * * * \\
(0.000)\end{array}$ & $\begin{array}{l}-0.000 \\
(0.000)\end{array}$ & $\begin{array}{c}0.001 \\
(0.001)\end{array}$ & $\begin{array}{c}0.001 * * \\
(0.001)\end{array}$ & $\begin{array}{l}-0.001 \\
(0.001)\end{array}$ \\
\hline Sunni & $\begin{array}{l}-0.034 \\
(0.045)\end{array}$ & $\begin{array}{l}-0.023 \\
(0.020)\end{array}$ & $\begin{array}{c}-0.207 * * * \\
(0.037)\end{array}$ & $\begin{array}{c}0.047 \\
(0.051)\end{array}$ & $\begin{array}{l}0.051^{*} \\
(0.029)\end{array}$ & $\begin{array}{c}0.205 * * * \\
(0.065)\end{array}$ & $\begin{array}{c}0.105 \\
(0.066)\end{array}$ & $\begin{array}{c}-0.202^{* *} \\
(0.091)\end{array}$ \\
\hline Alevite Shiite & $\begin{array}{c}-0.380 * * * \\
(0.060)\end{array}$ & $\begin{array}{l}0.044^{*} \\
(0.023)\end{array}$ & $\begin{array}{c}0.128^{* *} \\
(0.053)\end{array}$ & $\begin{array}{l}0.100^{*} \\
(0.058)\end{array}$ & $\begin{array}{c}0.041 \\
(0.036)\end{array}$ & $\begin{array}{c}-0.305^{* * *} \\
(0.075)\end{array}$ & $\begin{array}{c}-0.359^{* * *} \\
(0.067)\end{array}$ & $\begin{array}{c}0.324 * * * \\
(0.096)\end{array}$ \\
\hline Kurdish or Zaza Ethnicity & $\begin{array}{c}0.010 \\
(0.039)\end{array}$ & $\begin{array}{l}0.019 * \\
(0.012)\end{array}$ & $\begin{array}{l}-0.040 \\
(0.030)\end{array}$ & $\begin{array}{l}-0.037 \\
(0.034)\end{array}$ & $\begin{array}{l}-0.027 \\
(0.021)\end{array}$ & $\begin{array}{c}-0.190 * * * \\
(0.055)\end{array}$ & $\begin{array}{c}-0.194 * * * \\
(0.040)\end{array}$ & $\begin{array}{c}0.192 * * * \\
(0.049)\end{array}$ \\
\hline Arabic or Other Ethnicity & $\begin{array}{l}0.092^{*} \\
(0.050)\end{array}$ & $\begin{array}{c}0.012 \\
(0.013)\end{array}$ & $\begin{array}{c}-0.038 \\
(0.052)\end{array}$ & $\begin{array}{l}-0.018 \\
(0.033)\end{array}$ & $\begin{array}{c}-0.066^{* * *} \\
(0.024)\end{array}$ & $\begin{array}{l}0.076^{*} \\
(0.045)\end{array}$ & $\begin{array}{c}0.056 \\
(0.054)\end{array}$ & $\begin{array}{c}-0.072 \\
(0.050)\end{array}$ \\
\hline $\begin{array}{l}\mathrm{N} \\
1 \text { st Stage F-test } \\
\text { P-value }\end{array}$ & $\begin{array}{l}4,896 \\
5.907 \\
0.018 \\
\end{array}$ & $\begin{array}{l}4,896 \\
5.907 \\
0.018 \\
\end{array}$ & $\begin{array}{c}4,826 \\
6.172 \\
0.01 \\
\end{array}$ & $\begin{array}{c}4,195 \\
7.245 \\
0.01 \\
\end{array}$ & $\begin{array}{c}4,840 \\
6.462 \\
0.01 \\
\end{array}$ & $\begin{array}{c}3,396 \\
7.528 \\
0.01 \\
\end{array}$ & $\begin{array}{c}3,725 \\
6.302 \\
0.01 \\
\end{array}$ & $\begin{array}{c}2,876 \\
7.168 \\
0.01 \\
\end{array}$ \\
\hline
\end{tabular}

The entries in parentheses are standard errors of the estimated coefficients, clustered by birth province-age level. Twelve regions and five age groups yield 60 clusters. Standard errors, which are presented in brackets, are clustered by region of birth-exposure to the law, generating 24 clusters. A * indicates statistical level at the 10 percent level, ** stands for significance at the 5 percent level, $* * *$ indicates significance at the 1 percent level or better. Exposure to the Law $=1$ if the person was born between 1987 and 1994, it is zero if the year of birth is between 1980 and 1985. The 1986 cohort is excluded as exposure to the law depends on the exact day of birth for this cohort. If Kurdish or Zaza Ethnicity $=0$ and Arabic and Other Ethnicity $=0$, the individual is a Turk. Regressions include region fixed-effects and monthly dummies for the survey month, as well as dummies for region of birth. 
Table 7

The Impact of Education on the Propensity to Vote for an Islamic Party if Elections

Were held Today (in 2012) - Instrumental Variables Regressions with Control Variables Measuring Personal Economic Circumstances

\begin{tabular}{|c|c|c|c|}
\hline & $\begin{array}{l}\text { (1) } \\
\text { All } \\
\end{array}$ & $\begin{array}{c}(2) \\
\text { Males } \\
\end{array}$ & $\begin{array}{c}(3) \\
\text { Females }\end{array}$ \\
\hline Middle School Diploma & $\begin{array}{c}-0.422 * * \\
(0.177) \\
{[0.178]}\end{array}$ & $\begin{array}{l}-0.080 \\
(0.427) \\
{[0.411]}\end{array}$ & $\begin{array}{c}-0.545 * * * \\
(0.173) \\
{[0.201]}\end{array}$ \\
\hline Expect Personal Economic Hardship & $\begin{array}{c}-0.120 * * * \\
(0.017)\end{array}$ & $\begin{array}{c}-0.138 * * * \\
(0.020)\end{array}$ & $\begin{array}{c}-0.102 * * * \\
(0.021)\end{array}$ \\
\hline Can Make Ends Meet & $\begin{array}{c}0.077 * * * \\
(0.012)\end{array}$ & $\begin{array}{c}0.062 * * * \\
(0.017)\end{array}$ & $\begin{array}{c}0.091 * * * \\
(0.019)\end{array}$ \\
\hline Age & $\begin{array}{c}-0.027^{*} \\
(0.016)\end{array}$ & $\begin{array}{c}-0.057 * * \\
(0.028)\end{array}$ & $\begin{array}{l}-0.019 \\
(0.023)\end{array}$ \\
\hline Age Squared & $\begin{array}{c}0.000 \\
(0.000)\end{array}$ & $\begin{array}{l}0.001^{*} \\
(0.001)\end{array}$ & $\begin{array}{c}0.000 \\
(0.000)\end{array}$ \\
\hline Male & $\begin{array}{l}-0.024 \\
(0.031)\end{array}$ & & \\
\hline Sunni & $\begin{array}{c}0.096^{* *} \\
(0.043)\end{array}$ & $\begin{array}{l}0.110^{*} \\
(0.067)\end{array}$ & $\begin{array}{c}0.086 \\
(0.056)\end{array}$ \\
\hline Alevite Shiite & $\begin{array}{c}-0.362 * * * \\
(0.052)\end{array}$ & $\begin{array}{c}-0.332 * * * \\
(0.067)\end{array}$ & $\begin{array}{c}-0.384 * * * \\
(0.068)\end{array}$ \\
\hline Kurdish or Zaza Ethnicity & $\begin{array}{c}-0.190 * * * \\
(0.039)\end{array}$ & $\begin{array}{c}-0.178 * * * \\
(0.041)\end{array}$ & $\begin{array}{c}-0.202 * * * \\
(0.051)\end{array}$ \\
\hline Arabic or Other Ethnicity & $\begin{array}{c}0.052 \\
(0.032)\end{array}$ & $\begin{array}{c}0.067 \\
(0.055)\end{array}$ & $\begin{array}{c}0.053 \\
(0.040)\end{array}$ \\
\hline $\begin{array}{l}\mathrm{N} \\
\text { 1st Stage F-test } \\
\text { P-value }\end{array}$ & $\begin{array}{c}7,158 \\
24.37 \\
0.00\end{array}$ & $\begin{array}{c}3,698 \\
6.164 \\
0.01\end{array}$ & $\begin{array}{c}3,460 \\
17.39 \\
0.00\end{array}$ \\
\hline
\end{tabular}

The entries in parentheses are standard errors of the estimated coefficients, clustered by birth province-age level. Twelve regions and five age groups yield 60 clusters. Standard errors, which are presented in brackets, are clustered by region of birth-exposure to the law, generating 24 clusters. A* indicates statistical level at the 10 percent level, ** stands for significance at the 5 percent level, $* * *$ indicates significance at the 1 percent level or better. Exposure to the Law $=1$ if the person was born between 1987 and 1994, it is zero if the year of birth is between 1980 and 1985. The 1986 cohort is excluded as exposure to the law depends on the exact day of birth for this cohort. If Kurdish or Zaza Ethnicity $=0$ and Arabic and Other Ethnicity $=0$, the individual is a Turk. Regressions include region fixed-effects and monthly dummies for the survey month, as well as dummies for region of birth. 
Table 8

Exposure to the Law in the 2012 and 2008 Survey Years \& Graphical Representation of the Samples used in Tables 9-11

\begin{tabular}{|c|c|c|c|c|c|}
\hline (1) & (2) & & (3) & \multicolumn{2}{|l|}{ (4) } \\
\hline Exposure to the Law & Year of Birth & & Age in 2008 & Age in 2012 & \\
\hline No & 1979 & & 29 & 33 & \\
\hline No & 1980 & & $\rightarrow 28$ & 32 & \\
\hline No & 1981 & & 27 & 31 & \\
\hline No & 1982 & $\mathrm{C}$ & 26 & 30 & \\
\hline No & 1983 & & 25 & 29 & \\
\hline No & 1984 & & $\rightarrow 24 \leqslant$ & $28 \leftarrow$ & \\
\hline No & 1985 & & $23)^{\pi}$ & 27 & \\
\hline Uncertain & 1986 & & 22 & 26 & C \\
\hline Yes & 1987 & & 21 & 25 & \\
\hline Yes & 1988 & & 20 & $24 \leftarrow$ & \\
\hline Yes & 1989 & & 19 & 23 & \\
\hline Yes & 1990 & & 18 & 22 & \\
\hline Yes & 1991 & & 17 & 21 & \\
\hline Yes & 1992 & & 16 & 20 & \\
\hline Yes & 1993 & & 15 & 19 & \\
\hline Yes & 1994 & & 14 & 18 & \\
\hline
\end{tabular}


Table 9

Instrumental Variables Regressions Using Individuals Ages 23-25 or Ages 23-24 in 2008 and 2012

\begin{tabular}{|c|c|c|c|}
\hline VARIABLES & $\begin{array}{c}(2) \\
\text { Modern } \\
\text { (Males) }\end{array}$ & $\begin{array}{c}(3) \\
\text { Modern } \\
\text { (Females) }\end{array}$ & $\begin{array}{c}(4) \\
\text { Wears } \\
\text { Head Cover }\end{array}$ \\
\hline & \multicolumn{3}{|c|}{ Panel A: Ages 23, 24, 25} \\
\hline Middle School Diploma & $\begin{array}{c}0.841 * * * \\
(0.279) \\
{[0.282]}\end{array}$ & $\begin{array}{c}0.273 \\
(0.200) \\
{[0.202]}\end{array}$ & $\begin{array}{c}-0.869^{* * *} \\
(0.159) \\
{[0.159]}\end{array}$ \\
\hline Sunni & $\begin{array}{c}-0.166 * * * \\
(0.062)\end{array}$ & $\begin{array}{l}-0.000 \\
(0.077)\end{array}$ & $\begin{array}{c}0.031 \\
(0.105)\end{array}$ \\
\hline Alevite Shiite & $\begin{array}{c}0.082 \\
(0.104)\end{array}$ & $\begin{array}{c}0.412 * * * \\
(0.115)\end{array}$ & $\begin{array}{c}-0.285^{* *} \\
(0.133)\end{array}$ \\
\hline Kurdish or Zaza Ethnicity & $\begin{array}{c}0.006 \\
(0.065)\end{array}$ & $\begin{array}{c}0.019 \\
(0.052)\end{array}$ & $\begin{array}{l}-0.097^{*} \\
(0.055)\end{array}$ \\
\hline Arabic or Other Ethnicity & $\begin{array}{l}-0.049 \\
(0.075)\end{array}$ & $\begin{array}{l}-0.079 \\
(0.072)\end{array}$ & $\begin{array}{c}0.009 \\
(0.053)\end{array}$ \\
\hline $\begin{array}{l}\mathrm{N} \\
1 \text { st Stage F-test }\end{array}$ & $\begin{array}{l}1,258 \\
29.97\end{array}$ & $\begin{array}{l}1,211 \\
20.54\end{array}$ & $\begin{array}{l}1,215 \\
20.76\end{array}$ \\
\hline \multirow[t]{2}{*}{ P-value } & 0.00 & 0.00 & 0.00 \\
\hline & \multicolumn{3}{|c|}{ Panel B: Ages 23, 24} \\
\hline Middle School Diploma & $\begin{array}{c}1.154 * * * \\
(0.287) \\
{[0.240]}\end{array}$ & $\begin{array}{c}0.132 \\
(0.312) \\
{[0.291]}\end{array}$ & $\begin{array}{c}-0.570 * \\
(0.306) \\
{[0.300]}\end{array}$ \\
\hline Sunni & $\begin{array}{l}-0.032 \\
(0.100)\end{array}$ & $\begin{array}{c}0.003 \\
(0.120)\end{array}$ & $\begin{array}{c}0.007 \\
(0.102)\end{array}$ \\
\hline Alevite Shiite & $\begin{array}{l}0.263^{*} \\
(0.149)\end{array}$ & $\begin{array}{c}0.440 * * * \\
(0.158)\end{array}$ & $\begin{array}{c}-0.309 * * \\
(0.134)\end{array}$ \\
\hline Kurdish or Zaza Ethnicity & $\begin{array}{l}-0.009 \\
(0.098)\end{array}$ & $\begin{array}{c}0.009 \\
(0.073)\end{array}$ & $\begin{array}{l}-0.040 \\
(0.072)\end{array}$ \\
\hline Arabic or Other Ethnicity & $\begin{array}{l}-0.122 \\
(0.100)\end{array}$ & $\begin{array}{l}-0.049 \\
(0.090)\end{array}$ & $\begin{array}{c}0.015 \\
(0.062)\end{array}$ \\
\hline $\mathrm{N}$ & 824 & 746 & 752 \\
\hline 1st Stage F-test & 7.506 & 13.14 & 13.41 \\
\hline P-value & 0.00 & 0.00 & 0.00 \\
\hline
\end{tabular}

Individuals are of the same age in different years (2008 or 2012). Exposure to the Law $=1$ if the person was 23-25 years old in 2012 and it is zero if the person was 23-25 in 2008 (See Table 8). Regressions control for year-of-birth dummies. The entries in parentheses are standard errors of the estimated coefficients, clustered by birth province-age level. Standard errors, which are presented in brackets, are clustered by region of birth-exposure to the Law. Each model controls for birth year fixed effects. A * indicates statistical level at the 10 percent level, ** stands for significance at the 5 percent level, $* * *$ indicates significance at the 1 percent level or better. If Kurdish or Zaza Ethnicity $=0$ and Arabic and Other Ethnicity $=0$, the individual is a Turk. Regressions include region fixed-effects as well as dummies for region of birth. 


\section{Table 10A}

The Impact of Exposure to the Placebo Treatment on the Propensity to Have at Least Eight Years of Education-- OLS regressions

\begin{tabular}{lcc}
\hline & $(1)$ & $(2)$ \\
& Males & Females \\
\hline Exposure to the Placebo Law & -0.027 & 0.042 \\
& $(0.029)$ & $(0.030)$ \\
Sunni & {$[0.036]$} & {$[0.039]$} \\
Alevite Shiite & -0.077 & 0.080 \\
Kurdish or Zaza Ethnicity & $(0.053)$ & $(0.109)$ \\
Arabic or Other Ethnicity & -0.063 & $0.258^{* *}$ \\
& $(0.079)$ & $(0.085)$ \\
N & 0.040 & -0.157 \\
\end{tabular}

Exposure to the Placebo Law $=1$ if the person was between 23 and 25 years of age in 2008, it is zero if the respondent was between 27 and 29 years of age in 2012 (See Table 8). The entries in parentheses are standard errors of the estimated coefficients, clustered by birth province-age level. Standard errors, which are presented in brackets, are clustered at the birth region by exposure to the Placebo Law. Each model controls for birth year fixed effects. A * indicates statistical level at the 10 percent level, ** stands for significance at the 5 percent level, *** indicates significance at the 1 percent level or better. The 1986 cohort is excluded as exposure to the law depends on the exact day of birth for this cohort. If Kurdish or Zaza Ethnicity $=0$ and Arabic and Other Ethnicity $=0$, the individual is a Turk. Regressions include region fixed-effects as well as dummies for region of birth.

\section{Table 10B}

Reduced Form Estimates of the Impact of Placebo Treatment on Modernity and Wearing a Head Cover-- OLS Regressions

\begin{tabular}{lccc}
\hline VARIABLES & $\begin{array}{c}(2) \\
\text { Modern } \\
\text { (Males) }\end{array}$ & $\begin{array}{c}(3) \\
\text { Modern } \\
\text { (Females) }\end{array}$ & $\begin{array}{c}(4) \\
\text { Wears } \\
\text { Head Cover }\end{array}$ \\
\hline Exposure to the Placebo Law & -0.027 & 0.037 & 0.001 \\
& $(0.030)$ & $(0.035)$ & $(0.039)$ \\
& {$[0.043]$} & {$[0.049]$} & {$[0.044]$} \\
Sunni & $-0.192^{*}$ & -0.100 & 0.169 \\
Alevite Shiite & $(0.102)$ & $(0.106)$ & $(0.098)$ \\
Kurdish or Zaza Ethnicity & 0.123 & $0.313^{* *}$ & $-0.322^{* *}$ \\
Arabic or Other Ethnicity & $(0.103)$ & $(0.140)$ & $(0.119)$ \\
& -0.014 & -0.044 & $0.153^{* *}$ \\
$\mathrm{~N}$ & $(0.030)$ & $(0.055)$ & $(0.069)$ \\
& 0.045 & -0.048 & 0.026 \\
& $(0.072)$ & $(0.053)$ & $(0.068)$ \\
& & & \\
\end{tabular}

See notes to Table 10A. 


\section{Table 11}

\section{Difference in Difference Analysis using the 2008 and 2012 Surveys}

\begin{tabular}{lccc}
\hline VARIABLES & $\begin{array}{c}(2) \\
\text { Modern } \\
\text { (Males) }\end{array}$ & $\begin{array}{c}(3) \\
\text { Modern } \\
\text { (Females) }\end{array}$ & $\begin{array}{c}(4) \\
\text { Wears } \\
\text { Head Cover }\end{array}$ \\
\hline \multirow{3}{*}{ Young } & 0.050 & -0.027 & 0.009 \\
Year 2012 & $(0.041)$ & $(0.040)$ & $(0.041)$ \\
Young*(Year 2012) & $0.069^{* *}$ & $-0.072^{* * *}$ & 0.006 \\
& $(0.026)$ & $(0.013)$ & $(0.026)$ \\
& 0.029 & $0.094^{* *}$ & $-0.114^{* *}$ \\
Sunni & $(0.049)$ & $(0.044)$ & $(0.044)$ \\
Alevite Shiite & {$[0.051]$} & {$[0.049]$} & {$[0.049]$} \\
Kurdish or Zaza Ethnicity & $-0.168 * * *$ & $-0.135^{*}$ & $0.137 *$ \\
& $(0.058)$ & $(0.068)$ & $(0.071)$ \\
Arabic or Other Ethnicity & $0.158^{* *}$ & $0.298^{* * *}$ & $-0.333 * * *$ \\
& $(0.068)$ & $(0.086)$ & $(0.083)$ \\
& -0.037 & -0.037 & $0.128^{* *}$ \\
N & $(0.025)$ & $(0.035)$ & $(0.049)$ \\
& -0.019 & -0.031 & 0.041 \\
& $(0.048)$ & $(0.044)$ & $(0.045)$ \\
& & & \\
& 2,617 & 2,616 & 2,637 \\
\hline
\end{tabular}

The sample consists of those who are 23-25 or 27-29 in either 2008 or 2012.

Young $=1$ if the person is 23-25 years old. Year2012=1 if the person is surveyed in 2012 . No individual who is 23-29 in 2008 is exposed to the law. Those who are young (23-25) in 2012 are exposed to the law. The entries in parentheses are standard errors of the estimated coefficients, clustered by birth province-age level. Standard errors, which are presented in brackets, are clustered by region of birth-exposure to the Law. Each model controls for year of birth fixed effects. A * indicates statistical level at the 10 percent level, ** stands for significance at the 5 percent level, *** indicates significance at the one percent level or better. If Kurdish or Zaza Ethnicity $=0$ and Arabic and Other Ethnicity $=0$, the individual is a Turk. Regressions include region fixed-effects as well as dummies for region of birth. 
Table 12

The Impact of Education on Religiosity, the Propensity to Cast a Vote, and the Propensity to Vote for an Islamic Party-Instrumental Variables Regressions Controlling for Migration, Residential Location and Labor Force Participation Females

\begin{tabular}{|c|c|c|c|c|c|c|c|c|c|}
\hline VARIABLES & $\begin{array}{c}\text { (1) } \\
\text { Religious }\end{array}$ & $\begin{array}{c}(2) \\
\text { Atheist }\end{array}$ & $\begin{array}{c}(3) \\
\text { Modern }\end{array}$ & $\begin{array}{c}(4) \\
\text { Wears } \\
\text { Head } \\
\text { Cover } \\
\end{array}$ & $\begin{array}{l}(5) \\
\text { Voter } \\
2011\end{array}$ & $\begin{array}{l}(6) \\
\text { Voter } \\
\text { Now }\end{array}$ & $\begin{array}{c}(7) \\
\text { Voted } \\
\text { Islamic in } \\
2011 \\
\end{array}$ & $\begin{array}{c}(8) \\
\text { Islamic } \\
\text { Voter } \\
\text { Now } \\
\end{array}$ & $\begin{array}{c}(9) \\
\text { Never } \\
\text { Vote } \\
\text { Islamic } \\
\end{array}$ \\
\hline & \multicolumn{9}{|c|}{ Panel A: Baseline Results from Table 5} \\
\hline Middle School Diploma & $\begin{array}{c}-0.298^{* *} \\
(0.152)\end{array}$ & $\begin{array}{c}0.072 \\
(0.049)\end{array}$ & $\begin{array}{c}0.293^{* *} \\
(0.148)\end{array}$ & $\begin{array}{c}-0.399^{* *} \\
(0.203)\end{array}$ & $\begin{array}{c}0.044 \\
(0.119)\end{array}$ & $\begin{array}{c}0.046 \\
(0.084)\end{array}$ & $\begin{array}{c}-0.518^{* *} \\
(0.224)\end{array}$ & $\begin{array}{c}-0.537 * * * \\
(0.177)\end{array}$ & $\begin{array}{c}0.607^{* *} \\
(0.281)\end{array}$ \\
\hline $\begin{array}{l}\text { Observations } \\
\text { 1st Stage F-test } \\
\text { P-value }\end{array}$ & $\begin{array}{c}4,694 \\
15.80 \\
0.00\end{array}$ & $\begin{array}{c}4,694 \\
15.80 \\
0.00\end{array}$ & $\begin{array}{c}4,641 \\
15.66 \\
0.00\end{array}$ & $\begin{array}{c}4,659 \\
15.59 \\
0.00\end{array}$ & $\begin{array}{c}4,135 \\
14.38 \\
0.00\end{array}$ & $\begin{array}{c}4,612 \\
16.43 \\
0.00\end{array}$ & $\begin{array}{c}3,527 \\
13.16 \\
0.00\end{array}$ & $\begin{array}{c}3,489 \\
16.86 \\
0.00\end{array}$ & $\begin{array}{c}2,958 \\
9.66 \\
0.00\end{array}$ \\
\hline & \multicolumn{9}{|c|}{ Panel B: Results C ontrolling for Migration, Residential Location and Labor Force Participation } \\
\hline Middle School Diploma & $\begin{array}{l}-0.253 \\
(0.168)\end{array}$ & $\begin{array}{c}0.076 \\
(0.054)\end{array}$ & $\begin{array}{c}0.245 \\
(0.158)\end{array}$ & $\begin{array}{l}-0.339^{*} \\
(0.201)\end{array}$ & $\begin{array}{c}0.057 \\
(0.133)\end{array}$ & $\begin{array}{c}0.060 \\
(0.088)\end{array}$ & $\begin{array}{c}-0.495^{* *} \\
(0.250)\end{array}$ & $\begin{array}{c}-0.521 * * * \\
(0.191)\end{array}$ & $\begin{array}{l}0.590^{*} \\
(0.323)\end{array}$ \\
\hline Age & $\begin{array}{c}0.032 \\
(0.023)\end{array}$ & $\begin{array}{c}0.008 \\
(0.006)\end{array}$ & $\begin{array}{c}-0.070 * * * \\
(0.019)\end{array}$ & $\begin{array}{c}0.132 * * * \\
(0.020)\end{array}$ & $\begin{array}{c}0.092 * * * \\
(0.025)\end{array}$ & $\begin{array}{c}0.039 * * * \\
(0.010)\end{array}$ & $\begin{array}{l}-0.013 \\
(0.049)\end{array}$ & $\begin{array}{l}-0.021 \\
(0.027)\end{array}$ & $\begin{array}{c}0.030 \\
(0.057)\end{array}$ \\
\hline Age Squared & $\begin{array}{l}-0.001 \\
(0.000)\end{array}$ & $\begin{array}{l}-0.000 \\
(0.000)\end{array}$ & $\begin{array}{c}0.001 * * * \\
(0.000)\end{array}$ & $\begin{array}{c}-0.002 * * * \\
(0.000)\end{array}$ & $\begin{array}{c}-0.002 * * * \\
(0.000)\end{array}$ & $\begin{array}{c}-0.001 * * * \\
(0.000)\end{array}$ & $\begin{array}{c}0.000 \\
(0.001)\end{array}$ & $\begin{array}{c}0.000 \\
(0.000)\end{array}$ & $\begin{array}{l}-0.000 \\
(0.001)\end{array}$ \\
\hline Sunni & $\begin{array}{c}0.011 \\
(0.044)\end{array}$ & $\begin{array}{c}-0.036^{*} \\
(0.021)\end{array}$ & $\begin{array}{c}-0.090^{*} \\
(0.051)\end{array}$ & $\begin{array}{c}0.134 * * * \\
(0.046)\end{array}$ & $\begin{array}{l}-0.013 \\
(0.031)\end{array}$ & $\begin{array}{l}-0.003 \\
(0.023)\end{array}$ & $\begin{array}{l}0.118^{*} \\
(0.066)\end{array}$ & $\begin{array}{c}0.081 \\
(0.057)\end{array}$ & $\begin{array}{l}-0.073 \\
(0.067)\end{array}$ \\
\hline Alevite Shiite & $\begin{array}{c}-0.349 * * * \\
(0.057)\end{array}$ & $\begin{array}{c}0.030 \\
(0.024)\end{array}$ & $\begin{array}{c}0.231 * * * \\
(0.059)\end{array}$ & $\begin{array}{c}-0.221 * * * \\
(0.059)\end{array}$ & $\begin{array}{l}-0.033 \\
(0.045)\end{array}$ & $\begin{array}{l}-0.039 \\
(0.029)\end{array}$ & $\begin{array}{c}-0.327 * * * \\
(0.071)\end{array}$ & $\begin{array}{c}-0.422 * * * \\
(0.071)\end{array}$ & $\begin{array}{c}0.437 * * * \\
(0.090)\end{array}$ \\
\hline Kurdish or Zaza Ethnicity & $\begin{array}{c}0.040 \\
(0.037)\end{array}$ & $\begin{array}{c}0.029 * * \\
(0.012)\end{array}$ & $\begin{array}{c}-0.055^{*} \\
(0.033)\end{array}$ & $\begin{array}{c}0.087 * * \\
(0.040)\end{array}$ & $\begin{array}{c}0.003 \\
(0.026)\end{array}$ & $\begin{array}{l}-0.003 \\
(0.019)\end{array}$ & $\begin{array}{c}-0.232 * * * \\
(0.058)\end{array}$ & $\begin{array}{c}-0.202 * * * \\
(0.055)\end{array}$ & $\begin{array}{c}0.238 * * * \\
(0.069)\end{array}$ \\
\hline Arabic or Other Ethnicity & $\begin{array}{c}0.042 \\
(0.037)\end{array}$ & $\begin{array}{c}0.042 * * * \\
(0.013)\end{array}$ & $\begin{array}{l}-0.011 \\
(0.034)\end{array}$ & $\begin{array}{c}0.025 \\
(0.034)\end{array}$ & $\begin{array}{l}-0.017 \\
(0.024)\end{array}$ & $\begin{array}{c}0.025 \\
(0.025)\end{array}$ & $\begin{array}{c}0.055 \\
(0.039)\end{array}$ & $\begin{array}{c}0.057 \\
(0.040)\end{array}$ & $\begin{array}{l}-0.074 \\
(0.050)\end{array}$ \\
\hline Migrant & $\begin{array}{l}-0.007 \\
(0.022)\end{array}$ & $\begin{array}{l}-0.001 \\
(0.004)\end{array}$ & $\begin{array}{c}0.040^{* *} \\
(0.019)\end{array}$ & $\begin{array}{c}0.020 \\
(0.022)\end{array}$ & $\begin{array}{c}-0.033^{* *} \\
(0.014)\end{array}$ & $\begin{array}{l}-0.010 \\
(0.010)\end{array}$ & $\begin{array}{c}0.001 \\
(0.027)\end{array}$ & $\begin{array}{l}-0.007 \\
(0.029)\end{array}$ & $\begin{array}{c}0.022 \\
(0.030)\end{array}$ \\
\hline City & $\begin{array}{l}-0.053 \\
(0.035)\end{array}$ & $\begin{array}{l}-0.015^{*} \\
(0.009)\end{array}$ & $\begin{array}{c}0.125^{* * *} \\
(0.028)\end{array}$ & $\begin{array}{c}-0.135 * * * \\
(0.035)\end{array}$ & $\begin{array}{l}-0.000 \\
(0.023)\end{array}$ & $\begin{array}{l}-0.009 \\
(0.014)\end{array}$ & $\begin{array}{c}0.020 \\
(0.047)\end{array}$ & $\begin{array}{c}0.029 \\
(0.036)\end{array}$ & $\begin{array}{l}-0.035 \\
(0.061)\end{array}$ \\
\hline Metro Area & $\begin{array}{c}-0.074 * * * \\
(0.026)\end{array}$ & $\begin{array}{c}0.009 \\
(0.009)\end{array}$ & $\begin{array}{c}0.117 * * * \\
(0.031)\end{array}$ & $\begin{array}{c}-0.163 * * * \\
(0.038)\end{array}$ & $\begin{array}{l}-0.014 \\
(0.021)\end{array}$ & $\begin{array}{l}-0.008 \\
(0.015)\end{array}$ & $\begin{array}{l}-0.009 \\
(0.043)\end{array}$ & $\begin{array}{c}0.009 \\
(0.040)\end{array}$ & $\begin{array}{l}-0.014 \\
(0.055)\end{array}$ \\
\hline Labor Force Participation & $\begin{array}{c}-0.117^{* * *} \\
(0.041)\end{array}$ & $\begin{array}{l}-0.008 \\
(0.013)\end{array}$ & $\begin{array}{c}0.119^{* * *} \\
(0.035)\end{array}$ & $\begin{array}{c}-0.193^{* * *} \\
(0.042)\end{array}$ & $\begin{array}{l}-0.015 \\
(0.030)\end{array}$ & $\begin{array}{l}-0.039^{*} \\
(0.022)\end{array}$ & $\begin{array}{l}-0.046 \\
(0.063)\end{array}$ & $\begin{array}{c}-0.032 \\
(0.049)\end{array}$ & $\begin{array}{c}0.017 \\
(0.084)\end{array}$ \\
\hline $\mathrm{N}$ & 4,694 & 4,694 & 4,641 & 4,659 & 4,135 & 4,612 & 3,527 & 3,489 & 2,958 \\
\hline $1 \mathrm{st} \mathrm{St}$ & 16.18 & 16.18 & 16.37 & 16.23 & 13.55 & 16.95 & 12.08 & 15.89 & 7.684 \\
\hline P-value & 0.00 & 0.00 & 0.00 & 0.00 & 0.00 & 0.00 & 0.00 & 0.00 & 0.00 \\
\hline
\end{tabular}

The entries in parentheses are standard errors of the estimated coefficients, clustered by birth province-age level. Twelve regions and five age groups yield 60 clusters. A* indicates statistical level at the 10 percent level, ** stands for significance at the 5 percent level, ${ }^{* * *}$ indicates significance at the 1 percent level or better. Exposure to the Law=1 if the person was born between 1987 and 1994, it is zero if the year of birth is between 1980 and 1985. The 1986 cohort is excluded as exposure to the law depends on the exact day of birth for this cohort. If Kurdish or Zaza Ethnicity $=0$ and Arabic and Other Ethnicity $=0$, the individual is a Turk. Regressions include region fixed-effects and monthly dummies for the survey month, as well as dummies for region of birth. 


\section{References}

Azzi, C., and R. Ehrenberg. 1975. "Household Allocation of Time and Church Attendance." Journal of Political Economy 83(1), pp. 27-56.

Becker, G., and C. Mulligan. 1997. "The Endogenous Determination of Time Preference.” Quarterly Journal of Economics 112(3), pp.729-58.

Botero, J., Ponce, A., and A. Shleifer. 2012. "Education and the Quality of Government." NBER Working Paper, No. 18119.

Cakir, R., Irfan Bozan and B. Talu. 2004. "Imam Hatip Liseleri: Efsaneler ve Gercekler." TESEV, http://www.tesev.org.tr/.

Çarkoğlu ,Ali and Binnaz Toprak, Değişen T rkiye'de Din , Toplum ve Siyaset (Istanbul: TESEV, 2006), 19.

Campante, F., and D. Chor. 2012a. "Schooling, Political Participation, and the Economy." The Review of Economics and Statistics 94(4), pp. 841-859.

2012b. "Why Was the Arab World Poised for Revolution? Schooling, Economic Opportunities, and the Arab Spring." Journal of Economic Perspectives 26(2), pp.167-88.

Cannonier, C., and N. Mocan. 2013. "Empowering Women Through Education: Evidence from Sierra Leone.” NBER Working Paper, No.18016.

Card, D. 2001. "Estimating the Return to Schooling: Progress on Some Persistent Econometric Problems." Econometrica 69(5), pp. 1127-60.

Cullen, Julie Berry, Brian Jacob and Steven Levitt. 2005. "The Imapct of School Choice on Student Outcomes: An Analysis of the Chicago Public Schools." Journal of Public Economics. 89(5-6), pp. 729-60.

Cutler, D., and A. Lleras-Muney. 2010. "Understanding Differences in Health behaviors by Education.” Journal of Health Economics 29(1), pp. 1-28.

Dagi, I. 2005. "Transformation of Islamic Political Identity in Turkey: Rethinking the West and Westernization.” Turkish Studies 6(1), pp. 21-37.

Deaton, A. 2011. “Aging, Religion, and Health.” In Explorations in the Economics of Aging, David Wise (ed.) pp. 237-262. Chicago: University of Chicago Press.

Dee, T. 2004. “Are there Civic Returns to Education?” Journal of Public Economics 88(9), pp. 1697-1720. 
Degan, A., and A. Merlo. 2011. "A Structural Model of Turnout and Voting In Multiple Elections." Journal of the European Economic Association 9(2), pp. 209-245.

Di Pietro, G., and M. Delprato. 2009. "Education and Civic Outcomes in Italy." Public

Finance Review 37(4), pp.421-446.

Dulger, Ilhan. 2004. "Turkey: Rapid Coverage for Compulsory Education: Case study of the 1997Basic Education Program” World Bank, Washington DC.

Erbakan, Necmettin. 1975. "Milli Gör ş .” (Istanbul: Dergah Yayınları).

Fuller, D. 2004. “Turkey's Strategic Model: Myths and Realities.” The Washington Quarterly 27(3), pp. 51-64.

Glaeser, E., and B. Sacerdote. 2008. "Education and Religion.” Journal of Human Capital 2(2), pp.188-215.

Grossman, M. 2008. "The Relationship between Health and Schooling.” Eastern Economic Journal, 34:3, pp. 281-92.

Grossman, Michael. 1972. "On the Concept of Health Capital and the Demand for Health.” Journal of Political Economy, 80:2, pp. 223-255.

Gulesci, S., and E. Meyersson. 2013, "For the Love of the Republic' Education, Religion, and Empowerment." Working paper.

Hamermesh, Daniel S. and Jason Abrevaya. 2013. "Beauty is the Promise of Happiness?" European Economic Review, 64, pp. 351-68.

Hungerman, Daniel, 2011. "The Effect of Education on Religion: Evidence from Compulsory Schooling Laws.” NBER Working Paper, No. 16973.

Iannaccone, L. 1998. "Introduction to the Economics of Religion." Journal of Economic Literature 36(3), pp. 1465-1495.

Kirdar, Murat G. \& Dayioglu, Meltem \& Koc, Ismet, 2012. "Does longer compulsory education equalize educational attainment by gender, ethnicity, and socioeconomic background?," MPRA Paper 39995, University Library of Munich, Germany.

Kirdar, Murat G. \& Dayioglu, Meltem \& Koc, Ismet, 2011. " The Effect of Compulsory Schooling Laws on Teenage Marriage and Births in Turkey," IZA Discussion Paper No. 5887

KONDA Research and Consultancy. 2007. Religion, secularism and the veil in daily life. Available at http://www.konda.com.tr/html/dosyalar/ghdl\&t_en.pdf. 
KONDA Research and Consultancy. 2011. "İçki ve Sigara Kullanımı”. KONDA Şubat Barometresi. Siyasal ve Toplumsal Araştırmalar Dizisi. Available at http://konda.com.tr/icki_sigara.pdf.

Lavy, V.,and A. Zablotsky. 2011. "Mother's Schooling and Fertility under Low Female Labor Force Participation: Evidence from a Natural Experiment." NBER Working Paper, No. 16856.

McCleary, R. M., and R. Barro, and 2006a. "Religion and Political Economy in an International Panel." Journal for the Scientific Study of Religion 45(2), pp. 149-175.

$49-72$.

.2006b. "Religion and Economy." Journal of Economic Perspectives 20(2), pp.

Micklethwait, J., and A.Wooldridge. 2009. “God Is Back: How the Global Revival of Faith Is Changing the World.” Penguin Press. New York.

Miller, A., and R. Stark. 2002. "Gender and Religiousness: Can Socialization

Explanations Be Saved?” American Journal of Sociology 107(6), pp. 1399-1423.

Milligan, K., Moretti, E., and P. Oreopoulos. 2004. "Does Education Improve

Citizenship? Evidence from the U.S. and the U.K." Journal of Public Economics 88(910), pp. 1667-1695.

Mocan, Leyla. 2013. "The Impact of Education on Wages: Analysis of an Education Reform in Turkey." University of Pennsylvania Wharton School of Business Working Paper.

Mocan, Naci and Duha Altindag, 2013. "Education, Cognition, Health Knowledge and Health Behavior.” European Journal of Health Economics.

Mocan, Naci and Erdal Tekin. 2010. "Ugly Criminals." The Review of Economics and Statistics. 92(1), pp. 15-30.

Norris, P., and R. Inglehart. 2004. "Sacred and Secular: Religion and Politics Worldwide.” Cambridge University Press. New York.

Oreopoulos, P. 2006. "Estimating Average and Local Average Treatment Effects of Education when Compulsory Schooling Laws Really Matter.” American Economic Review 96(1), pp. 152-175.

Osili, U., and B. Long. 2008. "Does female schooling reduce fertility? Evidence from Nigeria.” Journal of Development Economics 87(1), pp. 57-75.

Pande, R. 2011. "Can Informed Voters Enforce Better Governance? Experiments in LowIncome Democracies.” Annual Review of Economics 3(1), pp. 215-237. 
Roy, O. 1994. The Failure of Political Islam. Harvard University Press.

Roy, O. 2012. The Transformation of the Arab World", Journal of Democracy, Volume 23, July

Siedler, Thomas. 2010. "Schooling and Citizenship in a Young Democracy: Evidence from Postwar Germany," Scandinavian Journal of Economics, Wiley Blackwell, vol. 112(2), pages 315-338, 06.

Suziedelis, A., and R. Potvin. 1981. "Sex Differences in Factors Affecting Religiousness among Catholic Adolescents." Journal for Scientific Study of Religion 20(1), pp. 38-50.

Taşpınar, Ömer. 2012. Turkey: The New Model?” in The Islamists are Coming: Who They Really are; Robin Wright (editor), Washington DC: Woodrow Wilson Center Press

TUIK. News Bulletin on Youth with Statistics. 2012.

http://www.tuik.gov.tr/PreHaberBultenleri.do?id=13509

Walter, T., and G. Davie. 1998. "The Religiosity of Women in the Modern West." British Journal of Sociology 49(4), pp. 640-60.

Wolfinger, R., and S. Rosenstone. 1980. “Who Votes?” Yale University Press. New Haven.

Yavuz, M. Hakan. 2000. "Cleansing Islam From the Public Sphere," Journal of International Affairs, 54(1), pp.21-40 
Appendix Figure 1

Proportion of Females with at Least Middle School Education

Turkish Statistical Institute Data

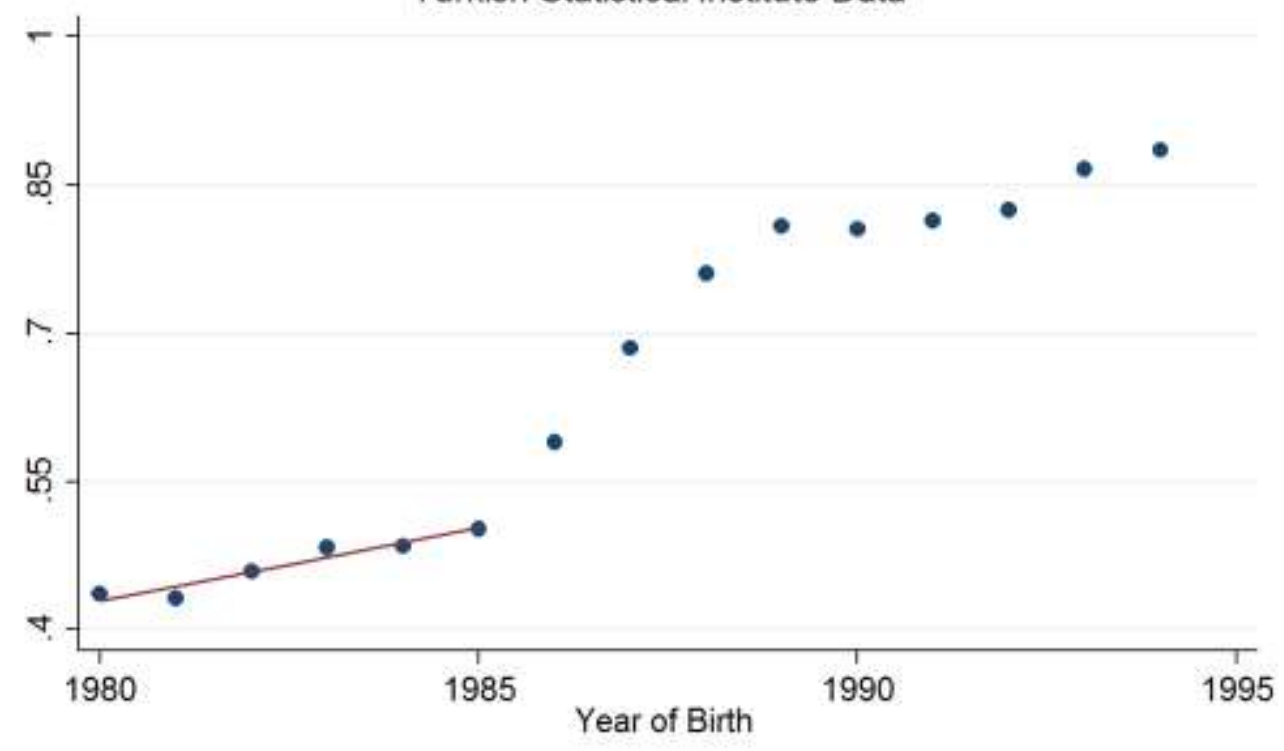




Appendix Table A1
Selected Attributes of a Sample of Countries in the Middle East and North Africa
\begin{tabular}{|l|c|c|c|c|} 
with Predominantly Muslim Populations \\
\hline Country & $\begin{array}{c}\text { GDP per capita } \\
\text { (current US\$ in } \\
\mathbf{2 0 1 2}\end{array}$ & $\begin{array}{c}\text { Democracy Index } \\
\text { in 2012 }\end{array}$ & $\begin{array}{c}\text { Average years of total } \\
\text { schooling in 2010, for } \\
\text { Age 25+ }\end{array}$ & Religiosity \\
\hline Iraq & 6,455 & 4.10 & 5.58 & 1.05 \\
\hline Iran, Islamic Rep. & $6,816^{*}$ & 1.98 & 7.84 & 1.28 \\
\hline Turkey & 10,666 & 5.76 & 6.47 & 1.36 \\
\hline Syrian Arab Republic & 3,289 & 1.63 & 4.88 & N/A \\
\hline Egypt, Arab Rep. & 3,187 & 4.56 & 6.37 & 1.05 \\
\hline Jordan & 4,945 & 3.76 & 8.64 & 1.05 \\
\hline Tunisia & 4,237 & 5.67 & 6.48 & N/A \\
\hline Algeria & 5,403 & 3.83 & 6.83 & 1.09 \\
\hline Morocco & 2,925 & 4.07 & 4.36 & 1.11 \\
\hline Libya & $10,456^{* *}$ & 5.15 & 7.52 & N/A \\
\hline
\end{tabular}

Selected Attributes of a Sample of European Countries

\begin{tabular}{|l|c|c|c|c|}
\hline Country & $\begin{array}{c}\text { GDP per capita (current } \\
\text { US\$ in 2012) }\end{array}$ & $\begin{array}{c}\text { Democracy } \\
\text { Index in 2012 }\end{array}$ & $\begin{array}{c}\text { Average years of total } \\
\text { schooling in 2010, for } \\
\text { Age 25+ }\end{array}$ & Religiosity \\
\hline Sweden & 55,245 & 9.73 & 11.61 & 2.91 \\
\hline Germany & 41,514 & 9.58 & 12.21 & 2.93 \\
\hline France & 39,772 & 7.88 & 10.43 & 2.74 \\
\hline England & 38,514 & 9.58 & 9.13 & 2.65 \\
\hline Spain & 29,195 & 8.02 & 10.35 & 2.76 \\
\hline Italy & 33,049 & 7.74 & 9.30 & 1.96 \\
\hline Slovenia & 22,001 & 7.88 & 11.70 & 2.68 \\
\hline
\end{tabular}

The data on GDP are from the World Bank. GDP is measured in 2012, except for Iran and Libya, for which the GDP information pertain to years 2011 and 2009, respectively.

The 2012 Democracy Index data are obtained from the Economist Intelligence Unit Report. The scale of the index is from 0 to 10 and the mean among 167 countries is 5.52 . The maximum of the index is 9.93 (Norway), the median is 5.86 (Bangladesh), and the minimum is 1.08 (North Korea).

The average years of total schooling for the population aged 25 and over is obtained for the year 2010. The average years of total schooling in all countries is 7.82 years. Source: Barro, Robert and Jong-Wha Lee, "A New Data Set of Educational Attainment in the World, 1950-2010." Journal of Development Economics.

The religiosity measure is computed from the World Values Survey (WVS). In the WVS the respondents were asked the following question: "How important is religion in your life? Would you say it is: Very important (coded as 1), Rather important (coded as 2), Not very important (coded as 3), Not at all important (coded as 4). The reported religiosity measure is the average answer of the country's respondents.

The religiosity measure is calculated using WVS 2005-2007 wave data, with the exception of Algeria, for which the most recent data are available from the 1999-2004 wave. The religiosity measure is not available for Syria, Tunisia, and Libya, as these countries are not in the WVS. The average for all countries in the 2005-2007 wave is 1.91 . 


\section{Appendix Table A2 \\ The Impact of Exposure to the Education Reform on the Propensity to Have at Least 5 years, at Least 8 Years, at Least 12 Years, and at Least 16 Years of Education -- OLS regressions}

\begin{tabular}{|c|c|c|c|c|}
\hline VARIABLES & $\begin{array}{c}\text { (1) } \\
\text { Primary + }\end{array}$ & $\begin{array}{c}(2) \\
\text { Middle } \\
\text { School }+ \\
\end{array}$ & $\begin{array}{c}\text { (3) } \\
\text { High } \\
\text { School }+ \\
\end{array}$ & $\begin{array}{c}(4) \\
\text { College }+\end{array}$ \\
\hline & \multicolumn{4}{|c|}{ Full sample } \\
\hline Exposure to the Law & $\begin{array}{c}-0.003 \\
(0.006)\end{array}$ & $\begin{array}{c}0.102 * * * \\
(0.022)\end{array}$ & $\begin{array}{c}0.123 * * * \\
(0.030)\end{array}$ & $\begin{array}{c}0.072 * * * \\
(0.021)\end{array}$ \\
\hline $\begin{array}{l}\text { Observations } \\
\text { Dependent Variable Mean } \\
\text { Dependent Variable SD }\end{array}$ & $\begin{array}{l}9,625 \\
0.974 \\
0.159 \\
\end{array}$ & $\begin{array}{l}9,625 \\
0.775 \\
0.418 \\
\end{array}$ & $\begin{array}{l}9,625 \\
0.597 \\
0.491 \\
\end{array}$ & $\begin{array}{l}9,625 \\
0.166 \\
0.372 \\
\end{array}$ \\
\hline Exposure to the Law & $\begin{array}{c}0.002 \\
(0.015)\end{array}$ & $\begin{array}{c}0.138 * * * \\
(0.035)\end{array}$ & $\begin{array}{c}0.120 * * * \\
(0.040)\end{array}$ & $\begin{array}{c}0.092 * * * \\
(0.026)\end{array}$ \\
\hline $\begin{array}{l}\text { Observations } \\
\text { Dependent Variable Mean } \\
\text { Dependent Variable SD }\end{array}$ & $\begin{array}{l}4,711 \\
0.959 \\
0.199 \\
\end{array}$ & $\begin{array}{l}4,711 \\
0.686 \\
0.464 \\
\end{array}$ & $\begin{array}{l}4,711 \\
0.515 \\
0.500 \\
\end{array}$ & $\begin{array}{l}4,711 \\
0.142 \\
0.349 \\
\end{array}$ \\
\hline Exposure to the Law & $\begin{array}{l}-0.006 \\
(0.007)\end{array}$ & $\begin{array}{c}0.062 * * \\
(0.025)\end{array}$ & $\begin{array}{c}0.121 * * * \\
(0.031)\end{array}$ & $\begin{array}{l}0.050^{*} \\
(0.026)\end{array}$ \\
\hline $\begin{array}{l}\text { Observations } \\
\text { Dependent Variable Mean } \\
\text { Dependent Variable SD }\end{array}$ & $\begin{array}{l}4,914 \\
0.989 \\
0.105\end{array}$ & $\begin{array}{l}4,914 \\
0.859 \\
0.348 \\
\end{array}$ & $\begin{array}{l}4,914 \\
0.675 \\
0.468 \\
\end{array}$ & $\begin{array}{l}4,914 \\
0.189 \\
0.392 \\
\end{array}$ \\
\hline
\end{tabular}

The entries in parentheses are standard errors of the estimated coefficients, clustered by birth province-age level. Twelve regions and five age groups yield 60 clusters. A * indicates statistical level at the 10 percent level, ** stands for significance at the 5 percent level, ${ }^{* * *}$ indicates significance at the 1 percent level or better. Exposure to the Law=1 if the person was born between 1987 and 1994, it is zero if the year of birth is between 1980 and 1985. The 1986 cohort is excluded as exposure to the law depends on the exact day of birth for this cohort. If Kurdish or Zaza Ethnicity $=0$ and Arabic and Other Ethnicity $=0$, the individual is a Turk. Regressions include region fixed-effects and monthly dummies for the survey month, as well as dummies for region of birth. 


\section{Appendix Table A3 \\ The Impact of Education on Religiosity, the Propensity to Cast a Vote, and the Propensity to Vote for an Islamic Party-Instrumental Variables Regressions Treatment is Coded $=\mathbf{0 . 3 3}$ for the 1986 Birth Cohort}

\begin{tabular}{|c|c|c|c|c|c|c|c|c|c|}
\hline VARIABLES & $\begin{array}{c}(1) \\
\text { Religious }\end{array}$ & $\begin{array}{c}(2) \\
\text { Atheist }\end{array}$ & $\begin{array}{c}(3) \\
\text { Modern }\end{array}$ & $\begin{array}{l}(6) \\
\text { Wears } \\
\text { Head } \\
\text { Cover } \\
\end{array}$ & $\begin{array}{l}(4) \\
\text { Voter } \\
2011\end{array}$ & $\begin{array}{l}(5) \\
\text { Voter } \\
\text { Now }\end{array}$ & $\begin{array}{c}7) \\
\text { Voted } \\
\text { Islamic } \\
\text { In } 2011 \\
\end{array}$ & $\begin{array}{c}(8) \\
\text { Islamic } \\
\text { Voter } \\
\text { Now } \\
\end{array}$ & $\begin{array}{c}9) \\
\text { Never } \\
\text { Vote } \\
\text { Islamic } \\
\end{array}$ \\
\hline & \multicolumn{9}{|c|}{ Panel A: Full Sample } \\
\hline Middle School & $\begin{array}{c}-0.475^{* *} \\
(0.188)\end{array}$ & $\begin{array}{l}0.083^{*} \\
(0.044)\end{array}$ & $\begin{array}{c}0.266 \\
(0.167)\end{array}$ & & $\begin{array}{l}-0.105 \\
(0.149)\end{array}$ & $\begin{array}{c}0.050 \\
(0.093)\end{array}$ & $\begin{array}{c}-0.370^{* *} \\
(0.184)\end{array}$ & $\begin{array}{c}-0.495^{* * *} \\
(0.173)\end{array}$ & $\begin{array}{c}0.524 * * \\
(0.221)\end{array}$ \\
\hline $\begin{array}{l}\text { Observations } \\
\text { 1st Stage F-test } \\
\text { P-value }\end{array}$ & $\begin{array}{c}10,297 \\
21.78 \\
0.00 \\
\end{array}$ & $\begin{array}{c}10,297 \\
21.78 \\
0.00 \\
\end{array}$ & $\begin{array}{c}10,167 \\
21.26 \\
0.00 \\
\end{array}$ & & $\begin{array}{c}9,016 \\
21.26 \\
0.00 \\
\end{array}$ & $\begin{array}{c}10,150 \\
23.60 \\
0.00 \\
\end{array}$ & $\begin{array}{c}7,507 \\
20.21 \\
0.00 \\
\end{array}$ & $\begin{array}{c}7,726 \\
24.71 \\
0.00 \\
\end{array}$ & $\begin{array}{c}6,312 \\
16.79 \\
0.00 \\
\end{array}$ \\
\hline Middle School & $\begin{array}{c}-0.391^{* *} \\
(0.159)\end{array}$ & $\begin{array}{c}0.070 \\
(0.051)\end{array}$ & $\begin{array}{c}0.321^{* *} \\
(0.148)\end{array}$ & $\begin{array}{r}\text { Pane } \\
-0.443 * * \\
(0.191)\end{array}$ & $\begin{array}{c}\text { Female } \\
0.061 \\
(0.120)\end{array}$ & $\begin{array}{c}\text { Sample } \\
0.069 \\
(0.084)\end{array}$ & $\begin{array}{c}-0.548^{* *} \\
(0.241)\end{array}$ & $\begin{array}{c}-0.609 * * * \\
(0.187)\end{array}$ & $\begin{array}{c}0.684^{* *} \\
(0.300)\end{array}$ \\
\hline $\begin{array}{l}\text { Observations } \\
\text { 1st Stage F-test } \\
\text { P-value }\end{array}$ & $\begin{array}{c}5,046 \\
14.38 \\
0.00\end{array}$ & $\begin{array}{c}5,046 \\
14.38 \\
0.00\end{array}$ & $\begin{array}{c}4,991 \\
14.53 \\
0.00\end{array}$ & $\begin{array}{c}5,010 \\
14.13 \\
0.00\end{array}$ & $\begin{array}{c}4,480 \\
12.36 \\
0.00\end{array}$ & $\begin{array}{c}4,961 \\
14.44 \\
0.00\end{array}$ & $\begin{array}{c}3,828 \\
11.42 \\
0.00\end{array}$ & $\begin{array}{c}3,745 \\
14.22 \\
0.00\end{array}$ & $\begin{array}{c}3,205 \\
8.291 \\
0.00\end{array}$ \\
\hline Middle School & $\begin{array}{c}-0.569 \\
(0.439)\end{array}$ & $\begin{array}{c}0.130 \\
(0.096)\end{array}$ & $\begin{array}{c}0.099 \\
(0.359)\end{array}$ & Pan & $\begin{array}{c}\text { C: Male } \\
-0.431 \\
(0.339)\end{array}$ & $\begin{array}{c}\text { imple } \\
0.025 \\
(0.229)\end{array}$ & $\begin{array}{c}0.015 \\
(0.398)\end{array}$ & $\begin{array}{l}-0.212 \\
(0.384)\end{array}$ & $\begin{array}{c}0.219 \\
(0.345)\end{array}$ \\
\hline $\begin{array}{l}\text { Observations } \\
\text { 1st Stage F-test } \\
\text { P-value }\end{array}$ & $\begin{array}{c}5,251 \\
6.889 \\
0.02\end{array}$ & $\begin{array}{c}5,251 \\
6.889 \\
0.02\end{array}$ & $\begin{array}{c}5,176 \\
6.761 \\
0.01\end{array}$ & & $\begin{array}{c}4,536 \\
7.707 \\
0.01\end{array}$ & $\begin{array}{c}5,189 \\
7.411 \\
0.01\end{array}$ & $\begin{array}{c}3,679 \\
8.421 \\
0.01\end{array}$ & $\begin{array}{c}3,981 \\
7.573 \\
0.01\end{array}$ & $\begin{array}{c}3,107 \\
8.296 \\
0.01\end{array}$ \\
\hline
\end{tabular}

The entries in parentheses are standard errors of the estimated coefficients, clustered by birth province-age level. Twelve regions and five age groups yield 60 clusters. A * indicates statistical level at the 10 percent level, ** stands for significance at the 5 percent level, *** indicates significance at the 1 percent level or better. Exposure to the Law=1 if the person was born between 1987 and 1994, it is zero if the year of birth is between 1980 and 1985. The exposure to the law indicator is set equal to 0.33 for 1986. If Kurdish or Zaza Ethnicity $=0$ and Arabic and Other Ethnicity $=0$, the individual is a Turk. Regressions include region fixed-effects and monthly dummies for the survey month, as well as dummies for region of birth. 


\section{Appendix Table A4 \\ The Impact of Education on Religiosity, the Propensity to Cast a Vote, and the Propensity to Vote for an Islamic Party-Instrumental Variables Regressions Treatment is Coded $=\mathbf{0 . 5 0}$ for the 1986 Birth Cohort}

\begin{tabular}{|c|c|c|c|c|c|c|c|c|c|}
\hline VARIABLES & $\begin{array}{c}(1) \\
\text { Religious }\end{array}$ & $\begin{array}{c}\text { (2) } \\
\text { Atheist }\end{array}$ & $\begin{array}{c}(3) \\
\text { Modern }\end{array}$ & $\begin{array}{l}(6) \\
\text { Wears } \\
\text { Head } \\
\text { Cover } \\
\end{array}$ & $\begin{array}{l}(4) \\
\text { Voter } \\
2011\end{array}$ & $\begin{array}{c}(5) \\
\text { Voter } \\
\text { Now }\end{array}$ & $\begin{array}{c}7) \\
\text { Voted } \\
\text { Islamic } \\
\text { In } 2011 \\
\end{array}$ & $\begin{array}{c}(8) \\
\text { Islamic } \\
\text { Voter } \\
\text { Now } \\
\end{array}$ & $\begin{array}{c}(9) \\
\text { Never } \\
\text { Vote } \\
\text { Islamic } \\
\end{array}$ \\
\hline & \multicolumn{9}{|c|}{ Panel A: Full Sample } \\
\hline Middle School & $\begin{array}{c}-0.411 * * \\
(0.197)\end{array}$ & $\begin{array}{l}0.082^{*} \\
(0.043)\end{array}$ & $\begin{array}{l}0.299^{*} \\
(0.171)\end{array}$ & & $\begin{array}{l}-0.149 \\
(0.145)\end{array}$ & $\begin{array}{c}0.013 \\
(0.095)\end{array}$ & $\begin{array}{l}-0.324 * \\
(0.177)\end{array}$ & $\begin{array}{c}-0.433^{* *} \\
(0.172)\end{array}$ & $\begin{array}{l}0.451^{* *} \\
(0.222)\end{array}$ \\
\hline $\begin{array}{l}\mathrm{N} \\
1 \text { st Stage F-test } \\
\text { P-value }\end{array}$ & $\begin{array}{c}10,297 \\
21.21 \\
0.00 \\
\end{array}$ & $\begin{array}{c}10,297 \\
21.21 \\
0.00 \\
\end{array}$ & $\begin{array}{c}10,167 \\
20.64 \\
0.00 \\
\end{array}$ & & $\begin{array}{c}9,016 \\
21.65 \\
0.00 \\
\end{array}$ & $\begin{array}{c}10,150 \\
23.31 \\
0.00 \\
\end{array}$ & $\begin{array}{c}7,507 \\
19.80 \\
0.00 \\
\end{array}$ & $\begin{array}{c}7,726 \\
24.12 \\
0.00 \\
\end{array}$ & $\begin{array}{c}6,312 \\
15.68 \\
0.00 \\
\end{array}$ \\
\hline Middle School & $\begin{array}{c}-0.305^{* *} \\
(0.152)\end{array}$ & $\begin{array}{c}0.071 \\
(0.049)\end{array}$ & $\begin{array}{c}0.305^{* *} \\
(0.148)\end{array}$ & $\begin{array}{r}\text { Pane } \\
-0.400^{* *} \\
(0.203)\end{array}$ & $\begin{array}{c}\text { Female } \\
0.040 \\
(0.118)\end{array}$ & $\begin{array}{c}\text { ample } \\
0.045 \\
(0.085)\end{array}$ & $\begin{array}{c}-0.503 * * \\
(0.222)\end{array}$ & $\begin{array}{c}-0.546^{* * *} \\
(0.178)\end{array}$ & $\begin{array}{c}0.601 * * \\
(0.288)\end{array}$ \\
\hline $\begin{array}{l}\mathrm{N} \\
\text { 1st Stage F-test } \\
\text { P-value }\end{array}$ & $\begin{array}{c}5,046 \\
15.25 \\
0.00 \\
\end{array}$ & $\begin{array}{c}5,046 \\
15.25 \\
0.00 \\
\end{array}$ & $\begin{array}{c}4,991 \\
15.03 \\
0.00 \\
\end{array}$ & $\begin{array}{c}5,010 \\
15.00 \\
0.00 \\
\end{array}$ & $\begin{array}{c}4,480 \\
13.70 \\
0.00 \\
\end{array}$ & $\begin{array}{c}4,961 \\
15.62 \\
0.00 \\
\end{array}$ & $\begin{array}{c}3,828 \\
12.48 \\
0.00 \\
\end{array}$ & $\begin{array}{c}3,745 \\
16.18 \\
0.00 \\
\end{array}$ & $\begin{array}{c}3,205 \\
9.175 \\
0.00 \\
\end{array}$ \\
\hline Middle School & $\begin{array}{l}-0.551 \\
(0.488)\end{array}$ & $\begin{array}{c}0.129 \\
(0.100)\end{array}$ & $\begin{array}{c}0.214 \\
(0.388)\end{array}$ & Pan & $\frac{C: \text { Male }}{-0.537}$ & $\begin{array}{l}\text { Imple } \\
-0.053 \\
(0.238)\end{array}$ & $\begin{array}{c}0.088 \\
(0.414)\end{array}$ & $\begin{array}{l}-0.133 \\
(0.404)\end{array}$ & $\begin{array}{c}0.150 \\
(0.350)\end{array}$ \\
\hline $\begin{array}{l}\mathrm{N} \\
\text { 1st Stage F-test } \\
\text { P-value }\end{array}$ & $\begin{array}{c}5,251 \\
6.101 \\
0.02 \\
\end{array}$ & $\begin{array}{c}5,251 \\
6.101 \\
0.02 \\
\end{array}$ & $\begin{array}{c}5,176 \\
6.240 \\
0.01 \\
\end{array}$ & & $\begin{array}{c}4,536 \\
7.088 \\
0.01 \\
\end{array}$ & $\begin{array}{c}5,189 \\
6.666 \\
0.01 \\
\end{array}$ & $\begin{array}{c}3,679 \\
7.446 \\
0.01 \\
\end{array}$ & $\begin{array}{c}3,981 \\
6.531 \\
0.01 \\
\end{array}$ & $\begin{array}{c}3,107 \\
7.039 \\
0.01 \\
\end{array}$ \\
\hline
\end{tabular}

The entries in parentheses are standard errors of the estimated coefficients, clustered by birth province-age level. Twelve regions and five age groups yield 60 clusters. A* indicates statistical level at the 10 percent level, $* *$ stands for significance at the 5 percent level, $* * *$ indicates significance at the 1 percent level or better. Exposure to the Law=1 if the person was born between 1987 and 1994, it is zero if the year of birth is between 1980 and 1985. The exposure to the law indicator is set equal to 0.5 for 1986 . If Kurdish or Zaza Ethnicity $=0$ and Arabic and Other Ethnicity $=0$, the individual is a Turk. Regressions include region fixed-effects and monthly dummies for the survey month, as well as dummies for region of birth. 


\begin{tabular}{|c|c|c|c|c|c|c|c|c|c|}
\hline \multicolumn{10}{|c|}{$\begin{array}{c}\text { Appendix Table A5 } \\
\text { The Impact of Education on Religiosity, the Propensity to Cast a Vote, and the } \\
\text { Propensity to Vote for an Islamic Party } \\
\text { Reduced Form Regressions }\end{array}$} \\
\hline & $\begin{array}{c}(1) \\
\text { Religious }\end{array}$ & $\begin{array}{c}\text { (2) } \\
\text { Atheist }\end{array}$ & $\begin{array}{c}(3) \\
\text { Modern }\end{array}$ & $\begin{array}{l}\text { (6) } \\
\text { Wears } \\
\text { Head } \\
\text { Cover }\end{array}$ & $\begin{array}{c}\text { (4) } \\
\text { Voter } \\
2011\end{array}$ & $\begin{array}{l}(5) \\
\text { Voter } \\
\text { Now }\end{array}$ & $\begin{array}{c}\text { (7) } \\
\text { Voted } \\
\text { Islamic } \\
\text { In } 2011 \\
\end{array}$ & $\begin{array}{c}\text { (8) } \\
\text { Islamic } \\
\text { Voter } \\
\text { Now } \\
\end{array}$ & $\begin{array}{l}\text { (9) } \\
\text { Never } \\
\text { Vote } \\
\text { Islamic }\end{array}$ \\
\hline \multirow[b]{2}{*}{ Middle School } & \multicolumn{9}{|c|}{ Panel A: Full Sample } \\
\hline & $\begin{array}{l}-0.041^{*} \\
(0.022)\end{array}$ & $\begin{array}{c}0.008^{* *} \\
(0.004)\end{array}$ & $\begin{array}{l}0.031^{*} \\
(0.019)\end{array}$ & & $\begin{array}{l}-0.015 \\
(0.013)\end{array}$ & $\begin{array}{c}0.000 \\
(0.010)\end{array}$ & $\begin{array}{c}-0.032^{*} \\
(0.018)\end{array}$ & $\begin{array}{c}-0.046^{* *} \\
(0.020)\end{array}$ & $\begin{array}{l}0.043 * \\
(0.023)\end{array}$ \\
\hline $\mathrm{N}$ & 9,590 & 9,590 & 9,467 & & 8,330 & 9,452 & 6,923 & 7,214 & 5,834 \\
\hline \multirow[b]{2}{*}{ Middle School } & \multicolumn{9}{|c|}{ Panel B: Female Sample } \\
\hline & $\begin{array}{l}-0.041^{*} \\
(0.024)\end{array}$ & $\begin{array}{c}0.010 \\
(0.006)\end{array}$ & $\begin{array}{l}0.041^{*} \\
(0.023)\end{array}$ & $\begin{array}{l}-0.055^{*} \\
(0.032)\end{array}$ & $\begin{array}{c}0.006 \\
(0.017)\end{array}$ & $\begin{array}{c}0.006 \\
(0.012)\end{array}$ & $\begin{array}{c}-0.066^{* *} \\
(0.026)\end{array}$ & $\begin{array}{c}-0.080^{* * *} \\
(0.024)\end{array}$ & $\begin{array}{c}0.070^{* *} \\
(0.030)\end{array}$ \\
\hline $\mathrm{N}$ & 4,694 & 4,694 & 4,641 & 4,659 & 4,135 & 4,612 & 3,527 & 3,489 & 2,958 \\
\hline \multirow[b]{2}{*}{ Middle School } & \multicolumn{9}{|c|}{ Panel C: Male Sample } \\
\hline & $\begin{array}{c}-0.034 \\
(0.030)\end{array}$ & $\begin{array}{c}0.008 \\
(0.006)\end{array}$ & $\begin{array}{c}0.016 \\
(0.024)\end{array}$ & & $\begin{array}{l}-0.036^{*} \\
(0.019)\end{array}$ & $\begin{array}{l}-0.005 \\
(0.015)\end{array}$ & $\begin{array}{c}0.005 \\
(0.027)\end{array}$ & $\begin{array}{l}-0.008 \\
(0.029)\end{array}$ & $\begin{array}{c}0.011 \\
(0.027)\end{array}$ \\
\hline $\mathrm{N}$ & 4,896 & 4,896 & 4,826 & & 4,195 & 4,840 & 3,396 & 3,725 & 2,876 \\
\hline
\end{tabular}

The entries in parentheses are standard errors of the estimated coefficients, clustered by birth province-age level. Twelve regions and five age groups yield 60 clusters. A * indicates statistical level at the 10 percent level, ** stands for significance at the 5 percent level, *** indicates significance at the 1 percent level or better. Exposure to the Law=1 if the person was born between 1987 and 1994, it is zero if the year of birth is between 1980 and 1985. The exposure to the law indicator is set equal to 0.5 for 1986 . If Kurdish or Zaza Ethnicity $=0$ and Arabic and Other Ethnicity $=0$, the individual is a Turk. Regressions include region fixed-effects and monthly dummies for the survey month, as well as dummies for region of birth. 


\section{Appendix Table A6 \\ The Impact of Education on Religiosity, the Propensity to Cast a Vote, and the Propensity to Vote for an Islamic Party-Education is Considered Exogenous}

OLS Regressions

\begin{tabular}{|c|c|c|c|c|c|c|c|c|c|}
\hline & $\begin{array}{c}(1) \\
\text { Religious }\end{array}$ & $\begin{array}{c}(2) \\
\text { Atheist }\end{array}$ & $\begin{array}{c}(3) \\
\text { Modern }\end{array}$ & $\begin{array}{l}(6) \\
\text { Wears } \\
\text { Head } \\
\text { Cover } \\
\end{array}$ & $\begin{array}{l}(4) \\
\text { Voter } \\
2011\end{array}$ & $\begin{array}{c}(5) \\
\text { Voter } \\
\text { Now }\end{array}$ & $\begin{array}{c}\quad(7) \\
\text { Voted } \\
\text { Islamic } \\
\text { In } 2011 \\
\end{array}$ & $\begin{array}{c}(8) \\
\text { Islamic } \\
\text { Voter } \\
\text { Now } \\
\end{array}$ & $\begin{array}{c}(9) \\
\text { Never } \\
\text { Vote } \\
\text { Islamic } \\
\end{array}$ \\
\hline & \multicolumn{9}{|c|}{ Panel A: Full Sample } \\
\hline $\begin{array}{l}\text { Middle } \\
\text { School }\end{array}$ & $\begin{array}{c}-0.158^{* * *} \\
(0.013)\end{array}$ & $\begin{array}{c}0.010 * * * \\
(0.003)\end{array}$ & $\begin{array}{c}0.193 * * * \\
(0.013)\end{array}$ & & $\begin{array}{c}-0.017^{*} \\
(0.009)\end{array}$ & $\begin{array}{c}-0.018^{* * *} \\
(0.006)\end{array}$ & $\begin{array}{c}-0.181^{* * *} \\
(0.012)\end{array}$ & $\begin{array}{c}-0.184^{* * *} \\
(0.012)\end{array}$ & $\begin{array}{c}0.171^{* * * *} \\
(0.013)\end{array}$ \\
\hline \multirow[t]{2}{*}{$\mathrm{N}$} & 9,590 & 9,590 & 9,467 & & 8,330 & 9,452 & 6,923 & 7,214 & 5,834 \\
\hline & \multicolumn{9}{|c|}{ Panel B: Female Sample } \\
\hline $\begin{array}{l}\text { Middle } \\
\text { School }\end{array}$ & $\begin{array}{c}-0.197 * * * \\
(0.016)\end{array}$ & $\begin{array}{c}0.011 * * * \\
(0.003)\end{array}$ & $\begin{array}{c}0.233^{* * *} \\
(0.016)\end{array}$ & $\begin{array}{c}-0.344 * * * \\
(0.016)\end{array}$ & $\begin{array}{l}-0.013 \\
(0.012)\end{array}$ & $\begin{array}{c}-0.022^{* *} \\
(0.008)\end{array}$ & $\begin{array}{c}-0.221^{* * * *} \\
(0.015)\end{array}$ & $\begin{array}{c}-0.227 * * * \\
(0.016)\end{array}$ & $\begin{array}{c}0.219^{* * * *} \\
(0.015)\end{array}$ \\
\hline $\mathrm{N}$ & 4,694 & 4,694 & 4,641 & 4,659 & 4,135 & 4,612 & 3,527 & 3,489 & 2,958 \\
\hline & \multicolumn{9}{|c|}{ Panel C: Male Sample } \\
\hline $\begin{array}{l}\text { Middle } \\
\text { School }\end{array}$ & $\begin{array}{c}-0.093^{* * *} \\
(0.021)\end{array}$ & $\begin{array}{l}0.010^{*} \\
(0.005)\end{array}$ & $\begin{array}{c}0.132 * * * \\
(0.018)\end{array}$ & & $\begin{array}{c}-0.024^{* *} \\
(0.011)\end{array}$ & $\begin{array}{l}-0.012 \\
(0.009)\end{array}$ & $\begin{array}{c}-0.110^{* * * *} \\
(0.022)\end{array}$ & $\begin{array}{c}-0.113^{* * * *} \\
(0.022)\end{array}$ & $\begin{array}{c}0.091^{* * * *} \\
(0.024)\end{array}$ \\
\hline $\mathrm{N}$ & 4,896 & 4,896 & 4,826 & & 4,195 & 4,840 & 3,396 & 3,725 & 2,876 \\
\hline
\end{tabular}

The entries in parentheses are standard errors of the estimated coefficients, clustered by birth province-age level. Twelve regions and five age groups yield 60 clusters. A* indicates statistical level at the 10 percent level, ** stands for significance at the 5 percent level, *** indicates significance at the 1 percent level or better. Exposure to the Law=1 if the person was born between 1987 and 1994, it is zero if the year of birth is between 1980 and 1985. The 1986 cohort is excluded as exposure to the law depends on the exact day of birth for this cohort. If Kurdish or Zaza Ethnicity $=0$ and Arabic and Other Ethnicity $=0$, the individual is a Turk. Regressions include region fixed-effects and monthly dummies for the survey month, as well as dummies for region of birth. 
Appendix Table A7

The Impact of Education on Religiosity, the Propensity to Cast a Vote, and the Propensity to Vote for an Islamic Party-Instrumental Variables Regressions

Excluding Students

\begin{tabular}{|c|c|c|c|c|c|c|c|c|c|}
\hline & $\begin{array}{c}(1) \\
\text { Religious }\end{array}$ & $\begin{array}{c}(2) \\
\text { Atheist }\end{array}$ & $\begin{array}{c}(3) \\
\text { Modern }\end{array}$ & $\begin{array}{c}(6) \\
\text { Wears } \\
\text { Head } \\
\text { Cover } \\
\end{array}$ & $\begin{array}{l}(4) \\
\text { Voter } \\
2011\end{array}$ & $\begin{array}{l}\text { (5) } \\
\text { Voter } \\
\text { Now }\end{array}$ & $\begin{array}{c}(7) \\
\text { Voted } \\
\text { Islamic } \\
\text { in } 2011 \\
\end{array}$ & $\begin{array}{c}(8) \\
\text { Islamic } \\
\text { Voter } \\
\text { Now } \\
\end{array}$ & $\begin{array}{c}9) \\
\text { Never } \\
\text { Vote } \\
\text { Islamic } \\
\end{array}$ \\
\hline & \multicolumn{9}{|c|}{ Panel A: Full Sample } \\
\hline $\begin{array}{l}\text { Middle } \\
\text { School }\end{array}$ & $\begin{array}{l}-0.318^{*} \\
(0.166)\end{array}$ & $\begin{array}{l}-0.017 \\
(0.033)\end{array}$ & $\begin{array}{c}0.057 \\
(0.144)\end{array}$ & & $\begin{array}{l}-0.185 \\
(0.146)\end{array}$ & $\begin{array}{l}-0.057 \\
(0.098)\end{array}$ & $\begin{array}{c}-0.392 * * \\
(0.190)\end{array}$ & $\begin{array}{c}-0.191 \\
(0.158)\end{array}$ & $\begin{array}{c}0.463^{* *} \\
(0.204)\end{array}$ \\
\hline $\begin{array}{l}\mathrm{N} \\
\text { 1st Stage F } \\
\text { P-value }\end{array}$ & $\begin{array}{c}7,401 \\
25.75 \\
0.00 \\
\end{array}$ & $\begin{array}{c}7,401 \\
25.75 \\
0.00 \\
\end{array}$ & $\begin{array}{c}7,301 \\
25.82 \\
0.00 \\
\end{array}$ & & $\begin{array}{r}6,897 \\
21.17 \\
0.00 \\
\end{array}$ & $\begin{array}{c}7,288 \\
26.78 \\
0.00 \\
\end{array}$ & $\begin{array}{c}5,856 \\
20.82 \\
0.00 \\
\end{array}$ & $\begin{array}{c}5,668 \\
24.03 \\
0.00 \\
\end{array}$ & $\begin{array}{c}4,920 \\
14.52 \\
0.00 \\
\end{array}$ \\
\hline & \multicolumn{9}{|c|}{ Panel B: Female Sample } \\
\hline $\begin{array}{l}\text { Middle } \\
\text { School }\end{array}$ & $\begin{array}{c}-0.287^{* *} \\
(0.122)\end{array}$ & $\begin{array}{c}0.017 \\
(0.034)\end{array}$ & $\begin{array}{c}0.219 \\
(0.137)\end{array}$ & $\begin{array}{c}-0.352 * * \\
(0.179)\end{array}$ & $\begin{array}{c}0.011 \\
(0.115)\end{array}$ & $\begin{array}{l}-0.010 \\
(0.088)\end{array}$ & $\begin{array}{c}-0.467^{* *} \\
(0.215)\end{array}$ & $\begin{array}{c}-0.355^{* *} \\
(0.155)\end{array}$ & $\begin{array}{c}0.507^{* *} \\
(0.249)\end{array}$ \\
\hline $\begin{array}{l}\mathrm{N} \\
\text { 1st Stage F } \\
\text { P-value }\end{array}$ & $\begin{array}{c}3,757 \\
17.21 \\
0.00 \\
\end{array}$ & $\begin{array}{c}3,757 \\
17.21 \\
0.00 \\
\end{array}$ & $\begin{array}{c}3,711 \\
17.10 \\
0.00 \\
\end{array}$ & $\begin{array}{c}3,748 \\
17.21 \\
0.00 \\
\end{array}$ & $\begin{array}{c}3,518 \\
14.64 \\
0.00 \\
\end{array}$ & $\begin{array}{c}3,687 \\
17.23 \\
0.00 \\
\end{array}$ & $\begin{array}{c}3,063 \\
14.74 \\
0.00 \\
\end{array}$ & $\begin{array}{c}2,858 \\
17.06 \\
0.00 \\
\end{array}$ & $\begin{array}{c}2,561 \\
10.67 \\
0.00 \\
\end{array}$ \\
\hline & \multicolumn{9}{|c|}{ Panel C: Male Sample } \\
\hline $\begin{array}{l}\text { Middle } \\
\text { School }\end{array}$ & $\begin{array}{l}-0.349 \\
(0.405)\end{array}$ & $\begin{array}{l}-0.086 \\
(0.084)\end{array}$ & $\begin{array}{l}-0.313 \\
(0.350)\end{array}$ & & $\begin{array}{l}-0.666 \\
(0.451)\end{array}$ & $\begin{array}{l}-0.167 \\
(0.245)\end{array}$ & $\begin{array}{c}-0.215 \\
(0.421)\end{array}$ & $\begin{array}{c}0.148 \\
(0.351)\end{array}$ & $\begin{array}{c}0.338 \\
(0.343)\end{array}$ \\
\hline $\begin{array}{l}\mathrm{N} \\
\text { 1st Stage F } \\
\text { P-value }\end{array}$ & $\begin{array}{c}3,644 \\
7.762 \\
0.02 \\
\end{array}$ & $\begin{array}{c}3,644 \\
7.762 \\
0.02 \\
\end{array}$ & $\begin{array}{c}3,590 \\
8.266 \\
0.01 \\
\end{array}$ & & $\begin{array}{c}3,379 \\
6.354 \\
0.01 \\
\end{array}$ & $\begin{array}{c}3,601 \\
8.496 \\
0.01 \\
\end{array}$ & $\begin{array}{c}2,793 \\
6.867 \\
0.01 \\
\end{array}$ & $\begin{array}{c}2,810 \\
7.363 \\
0.01 \\
\end{array}$ & $\begin{array}{c}2,359 \\
6.192 \\
0.01 \\
\end{array}$ \\
\hline
\end{tabular}

The entries in parentheses are standard errors of the estimated coefficients, clustered by birth province-age level. Twelve regions and five age groups yield 60 clusters. A * indicates statistical level at the 10 percent level, ** stands for significance at the 5 percent level, *** indicates significance at the 1 percent level or better. Exposure to the Law=1 if the person was born between 1987 and 1994, it is zero if the year of birth is between 1980 and 1985. The exposure to the law indicator is set equal to 0.5 for 1986 . If Kurdish or Zaza Ethnicity $=0$ and Arabic and Other Ethnicity $=0$, the individual is a Turk. Regressions include region fixed-effects and monthly dummies for the survey month, as well as dummies for region of birth. 


\section{Appendix TableA8}

Descriptive Statistics of the 2008 Sample used in Tables 9-11

\begin{tabular}{|c|c|c|c|c|}
\hline Variable & $\begin{array}{c}\text { Men } \\
\text { Ages } \\
\text { (23 to } 25) \\
\text { in } 2008\end{array}$ & $\begin{array}{c}\frac{\text { Women }}{\text { Ages }} \\
\text { (23 to } 25) \\
\text { in } 2008\end{array}$ & $\begin{array}{c}\text { Men } \\
\text { Ages } \\
(23 \text { to } 25) \\
\text { or } \\
(27 \text { to } 29) \\
\text { in } 2008\end{array}$ & $\begin{array}{c}\frac{\text { Women }}{\text { Ages }} \\
\text { (23 to } 25) \\
\text { or } \\
(27 \text { to } 29) \\
\text { in } 2008\end{array}$ \\
\hline Middle School Diploma & $\begin{array}{c}0.807 \\
(0.396)\end{array}$ & $\begin{array}{c}0.623 \\
(0.486)\end{array}$ & $\begin{array}{c}0.769 \\
(0.422)\end{array}$ & $\begin{array}{c}0.544 \\
(0.499)\end{array}$ \\
\hline Modern & $\begin{array}{c}0.289 \\
(0.454)\end{array}$ & $\begin{array}{c}0.367 \\
(0.483)\end{array}$ & $\begin{array}{c}0.270 \\
(0.444)\end{array}$ & $\begin{array}{c}0.361 \\
(0.481)\end{array}$ \\
\hline Sunni & $\begin{array}{c}0.914 \\
(0.281)\end{array}$ & $\begin{array}{c}0.911 \\
(0.285)\end{array}$ & $\begin{array}{c}0.922 \\
(0.269)\end{array}$ & $\begin{array}{c}0.913 \\
(0.283)\end{array}$ \\
\hline Alevite Shiite & $\begin{array}{c}0.065 \\
(0.246)\end{array}$ & $\begin{array}{c}0.046 \\
(0.211)\end{array}$ & $\begin{array}{c}0.061 \\
(0.239)\end{array}$ & $\begin{array}{c}0.053 \\
(0.224)\end{array}$ \\
\hline Kurdish or Zaza Ethnicity & $\begin{array}{c}0.106 \\
(0.308)\end{array}$ & $\begin{array}{c}0.082 \\
(0.275)\end{array}$ & $\begin{array}{c}0.104 \\
(0.306)\end{array}$ & $\begin{array}{c}0.084 \\
(0.278)\end{array}$ \\
\hline Arabic or Other Ethnicity & $\begin{array}{c}0.055 \\
(0.228)\end{array}$ & $\begin{array}{c}0.041 \\
(0.199)\end{array}$ & $\begin{array}{c}0.048 \\
(0.215)\end{array}$ & $\begin{array}{c}0.028 \\
(0.165)\end{array}$ \\
\hline Observations & 239 & 245 & 522 & 502 \\
\hline
\end{tabular}

Standard deviations are in parentheses. 


\section{Appendix Table A9 \\ The Impact of Exposure to the Education Reform on the Propensity to Have at Least Eight Years of Education OLS Regressions by Region and Gender}

\begin{tabular}{|c|c|c|c|}
\hline & $\begin{array}{l}\text { (1) } \\
\text { All }\end{array}$ & $\begin{array}{c}\text { (2) } \\
\text { Male }\end{array}$ & $\begin{array}{c}(3) \\
\text { Female }\end{array}$ \\
\hline \multirow[b]{2}{*}{ Exposure to the Law } & \multicolumn{3}{|c|}{ Panel A: Full Sample } \\
\hline & $\begin{array}{c}0.102 * * * \\
(0.022)\end{array}$ & $\begin{array}{c}0.062 * * \\
(0.025)\end{array}$ & $\begin{array}{c}0.138^{* * *} \\
(0.035)\end{array}$ \\
\hline Observations & 9,625 & 4,914 & 4,711 \\
\hline R-squared & 0.190 & 0.100 & 0.223 \\
\hline & \multicolumn{3}{|c|}{ Panel B: Eastern Turkey } \\
\hline Exposure to the Law & $\begin{array}{c}0.091 * * * \\
(0.030)\end{array}$ & $\begin{array}{c}0.075^{* *} \\
(0.034)\end{array}$ & $\begin{array}{c}0.114^{* *} \\
(0.055)\end{array}$ \\
\hline Observations & 2,815 & 1,479 & 1,336 \\
\hline R-squared & 0.263 & 0.143 & 0.318 \\
\hline \multirow[b]{2}{*}{ Exposure to the Law } & \multicolumn{3}{|c|}{ Panel C: Western Turkey } \\
\hline & $\begin{array}{c}0.106^{* * *} \\
(0.025)\end{array}$ & $\begin{array}{c}0.057 \\
(0.034)\end{array}$ & $\begin{array}{c}0.148 * * * \\
(0.035)\end{array}$ \\
\hline Observations & 6,810 & 3,435 & 3,375 \\
\hline R-squared & 0.169 & 0.090 & 0.199 \\
\hline
\end{tabular}

The entries in parentheses are standard errors of the estimated coefficients, clustered by province-age level. Twelve regions and five age groups yield 60 clusters. A * indicates statistical level at the 10 percent level, ** stands for significance at the 5 percent level, *** indicates significance at the 1 percent level or better. Exposure to the Law=1 if the person was born between 1987 and 1994, it is zero if the year of birth is between 1980 and 1985. The 1986 cohort is excluded as exposure to the law depends on the exact day of birth for this cohort. If Kurdish or Zaza Ethnicity $=0$ and Arabic and Other Ethnicity $=0$, the individual is a Turk. Regressions include region fixed-effects and monthly dummies for the survey month. Each model estimates controls for the same set of variables that are specified in Table 2. 


\section{Appendix Table A10 \\ The Impact of Education on Religiosity, the Propensity to Cast a Vote, and the Propensity to Vote for an Islamic Part Instrumental Variables Regressions by Region}

Females

\begin{tabular}{|c|c|c|c|c|c|c|c|c|c|}
\hline & $\begin{array}{c}(1) \\
\text { Religious }\end{array}$ & $\begin{array}{c}\text { (2) } \\
\text { Atheist }\end{array}$ & $\begin{array}{c}(3) \\
\text { Modern }\end{array}$ & $\begin{array}{c}(4) \\
\text { Wears } \\
\text { Head } \\
\text { Cover } \\
\end{array}$ & $\begin{array}{l}(5) \\
\text { Voter } \\
2011\end{array}$ & $\begin{array}{l}\text { (6) } \\
\text { Voter } \\
\text { Now }\end{array}$ & $\begin{array}{c}(7) \\
\text { Voted } \\
\text { Islamic } \\
\text { In } 2011 \\
\end{array}$ & $\begin{array}{c}\text { (8) } \\
\text { Islamic } \\
\text { Voter } \\
\text { Now } \\
\end{array}$ & $\begin{array}{c}(9) \\
\text { Never } \\
\text { Vote } \\
\text { Islamic } \\
\end{array}$ \\
\hline & \multicolumn{9}{|c|}{ Females in Eastern Turkey } \\
\hline $\begin{array}{l}\text { Middle } \\
\text { School }\end{array}$ & $\begin{array}{l}-0.357 \\
(0.415)\end{array}$ & $\begin{array}{l}-0.093 \\
(0.088)\end{array}$ & $\begin{array}{l}-0.039 \\
(0.397)\end{array}$ & $\begin{array}{l}-0.321 \\
(0.402)\end{array}$ & $\begin{array}{c}0.683 \\
(0.455)\end{array}$ & $\begin{array}{c}0.142 \\
(0.186)\end{array}$ & $\begin{array}{l}-0.338 \\
(0.342)\end{array}$ & $\begin{array}{l}-0.087 \\
(0.318)\end{array}$ & $\begin{array}{c}0.274 \\
(0.430)\end{array}$ \\
\hline $\begin{array}{l}\mathrm{N} \\
\text { 1st Stage } \\
\mathrm{P} \text {-value }\end{array}$ & $\begin{array}{l}1,331 \\
4.416 \\
0.0500\end{array}$ & $\begin{array}{c}1,331 \\
4.416 \\
0.0500\end{array}$ & $\begin{array}{l}1,319 \\
4.772 \\
0.0412\end{array}$ & $\begin{array}{l}1,325 \\
4.772 \\
0.0573 \\
\end{array}$ & $\begin{array}{c}1,186 \\
3.286 \\
0.0853 \\
\end{array}$ & $\begin{array}{c}1,318 \\
4.660 \\
0.0440\end{array}$ & $\begin{array}{c}1,026 \\
5.243 \\
0.0259 \\
\end{array}$ & $\begin{array}{c}1,035 \\
6.662 \\
0.0229 \\
\end{array}$ & $\begin{array}{c}886 \\
4.171 \\
0.0634 \\
\end{array}$ \\
\hline & \multicolumn{9}{|c|}{ Females in Western Turkey } \\
\hline $\begin{array}{l}\text { Middle } \\
\text { School }\end{array}$ & $\begin{array}{l}-0.311^{*} \\
(0.160)\end{array}$ & $\begin{array}{c}0.129^{* *} \\
(0.061)\end{array}$ & $\begin{array}{c}0.393^{* *} \\
(0.170)\end{array}$ & $\begin{array}{l}-0.454^{*} \\
(0.239)\end{array}$ & $\begin{array}{l}-0.113 \\
(0.142)\end{array}$ & $\begin{array}{c}0.014 \\
(0.102)\end{array}$ & $\begin{array}{c}-0.597 * * * \\
(0.225)\end{array}$ & $\begin{array}{c}-0.770 * * * \\
(0.211)\end{array}$ & $\begin{array}{c}0.772 * * \\
(0.314)\end{array}$ \\
\hline $\begin{array}{l}\mathrm{N} \\
\text { 1st Stage F-test } \\
\text { P-value }\end{array}$ & $\begin{array}{c}3,363 \\
16.91 \\
0.00 \\
\end{array}$ & $\begin{array}{c}3,363 \\
16.91 \\
0.00 \\
\end{array}$ & $\begin{array}{c}3,322 \\
16.87 \\
0.00 \\
\end{array}$ & $\begin{array}{c}3,334 \\
16.87 \\
0.00 \\
\end{array}$ & $\begin{array}{c}2,949 \\
15.16 \\
0.00\end{array}$ & $\begin{array}{c}3,294 \\
17.29 \\
0.00 \\
\end{array}$ & $\begin{array}{c}2,501 \\
10.54 \\
0.00 \\
\end{array}$ & $\begin{array}{c}2,454 \\
13.22 \\
0.00 \\
\end{array}$ & $\begin{array}{c}2,072 \\
6.479 \\
0.00 \\
\end{array}$ \\
\hline
\end{tabular}

The entries in parentheses are standard errors of the estimated coefficients, clustered by birth province-age level. Twelve regions and five age groups yield 60 clusters. A * indicates statistical level at the 10 percent level, ${ }^{* *}$ stands for significance at the 5 percent level, $* * *$ indicates significance at the 1 percent level or better. Exposure to the Law=1 if the person was born between 1987 and 1994, it is zero if the year of birth is between 1980 and 1985. The 1986 cohort is excluded as exposure to the law depends on the exact day of birth for this cohort. If Kurdish or Zaza Ethnicity $=0$ and Arabic and Other Ethnicity $=0$, the individual is a Turk. Regressions include region fixed-effects and monthly dummies for the survey month, as well as dummies for region of birth. 


\section{Islamic Political Movement in Turkey and the Headscarf Issue}

\section{A Brief History of Islamic Political Movement in Turkey:}

Amended in 1937, Article 2 of the Turkish constitution states that the Republic of Turkey is secular state, and the constitution does not permit the establishment of political parties with explicit written references to any religion in party statutes. ${ }^{44}$ However, an influential Islamic political movement started under the leadership of Necmettin Erbakan in the late 1960s. In 1969, Erbakan published a manifesto named National View ${ }^{45}$ (Milli Gör ş) . Inspired by the Ottoman history, and with intellectual connections to Nakşibendi Sufi order, the National View was the inspiration of an Islamic political movement, called National View Movement (Milli Gorus Hareketi). ${ }^{46}$ In 1970, Necmettin Erbakan established the National Order Party (Milli Nizam Partisi), the first Islamic party in Turkey (Dagi 2005). Since then, most political parties with Islamic preferences were either established as direct descendants of the National Order Party or they were offshoots of it. In the aftermath of the 1971 military intervention, the Constitutional Court of Turkey closed the National Order Party for exploiting religion for political purposes (Dagi 2005). Only one year after the closure of the National Order Party, in 1972, Necmettin Erbakan established another Islamic political party, the National Salvation Party ${ }^{47}$ (Milli Selamet Partisi). The National Salvation Party received a significant amount of recognition in the 1973 general elections. Receiving $11.8 \%$ of the popular vote, the National Salvation Party secured 48 of the 450 seats in the Parliament (The Grand National Assembly of Turkey). Even though the party's popular support

\footnotetext{
${ }^{44} \mathrm{http}: / /$ global.tbmm.gov.tr/docs/constitution_en.pdf

${ }^{45}$ Milli Gör ş

${ }^{46}$ Milli Gör ş Hareketi

${ }^{47}$ Milli Selamet Partisi
} 
went down in the 1977 general elections (receiving $8.5 \%$ of the popular vote, gaining 24 of the 450 seats), the Islamic National Salvation Party managed to be part of a coalition government—led by Republican People's Party (Cumhuriyet Halk Partisi) and its leader Bülent Ecevit.

Following the military coup of 1980 , all political parties were shut down by the Turkish military in 1981. Even though Necmettin Erbakan was banned from active politics along with a total of 242 politicians from all over the political spectrum, including major figures of Turkish politics (e.g. Süleyman Demirel, Bülent Ecevit, and Alparslan T rke ş), Erbakan's and his party's legacy continued with the establishment of the Welfare Party (Refah Partisi) in 1983. Despite being banned from active politics, Necmettin Erbakan exerted strong control on the Welfare Party (Dagi 2005). He returned to active politics after the 1981 ban was lifted following a referendum in 1987. The Islamic Welfare Party received 4.8\%, and 7\% of the popular vote in the 1983 and 1987 elections, respectively, although it could not secure any seats in the parliament because its share of votes were below the nation-wide $10 \%$ threshold required by law. In the 1991 election the Welfare Party received $16.9 \%$ of the popular vote and secured 62 of the 450 seats in the Parliament.

In the 1990s, the Welfare Party gained strong popular support and increased its vote share in consecutive elections. The 1994 local election was a major turning point for the Islamic political movement. The Welfare Party received $19.1 \%$ of the total vote and won mayoral elections in 28 of the 76 provinces including Ankara, the capital, and Istanbul, the largest city in Turkey. ${ }^{48}$ Receiving $21.4 \%$ of the popular vote, Erbakan's Islamic Welfare Party became the leading party at the 1995 general election. The Welfare

${ }^{48}$ Currently Turkey has 81 provinces. 
Party's victory in the 1995 elections generated a strong secularist reaction, led by the secular military and the followers of the Kemal Atatürk, the founding father of the modern Turkish Republic. The major criticism of the Welfare Party and Necmettin Erbakan was centered on a potential secret Islamic political agenda. That is, the Armed Forces and followers of Mustafa Kemal Atatürk believed that Necmettin Erbakan and his supporters wanted to transform the secular Turkish Republic into a country ruled by the Sharia (Islamic Law). Therefore, due to strong opposition, other political parties refused to form a coalition with the Welfare party after the 1995 general elections. Hence, the $53^{\text {rd }}$ government of Turkey was established as a coalition of two center-right parties: The Motherland Party (Anavatan Partisi) and True Path Party (Dogru Yol Partisi) even though these two parties together did not have enough seats to constitute the majority in the parliament. ${ }^{49}$

As the $53^{\text {rd }}$ government did not last long due to the conflicts between the Motherland Party and True Path Party, Necmettin Erbakan was charged by the President of Turkey in 1996 with the formation of the $54^{\text {th }}$ government, and this government was established as a coalition between Erbakan's Welfare Party and the True Path Party, Erbakan being the Prime Minister. This development heightened the concern of the military and secularists. Therefore, on February 28 1997, the Turkish National Security Council, consisting mainly of military officials, decided to adopt a number of actions to curb the rise of political Islam in Turkey (Yavuz 2000). In June 1997, Erbakan resigned as Prime Minister to provide the opportunity for his coalition partner Tansu Ciller to be the head of the government instead. This resignation, however, provided the opportunity

\footnotetext{
${ }^{49}$ Bulent Ecevit's Democratic Left Party agreed to provide external support to guarantee necessary majority in the GNTA.
} 
for the President of the country to task a different political party to form a government. Consequently, a new coalition was formed between three secular parties (Anavatan Partisi, Demokratik Sol Parti and Demokrat Türkiye Partisi) on June 30 1997, and the leader of Anavatan Partisi, Mesut Yilmaz became the Prime Minister of the $55^{\text {th }}$ government.

Meanwhile, the Constitutional Court of Turkey closed the Welfare Party in January 1998 based on the charge of activities against the secular Turkish state, and banned its leader Necmettin Erbakan from participating in active politics for five years. Nevertheless, a successor of the Welfare party was quickly established in 1998 under the name of the Virtue Party (Fazilet Partisi). The Constitutional Court closed the Virtue Party in 2001 for violation of the secularist articles of the constitution. Following the closure of the Virtue Party in 2001, a major divide took place among the political leaders of the Islamic movement. The supporters of Necmettin Erbakan founded the Felicity Party (Saadet Partisi) as the successor of the Virtue Party. A second group, on the other hand, led by Recep Tayyip Erdogan, the former mayor of Istanbul and the current prime Minister, and Abdullah Gul, the current president of Turkey formed the Justice and Development Party (AKP) in the same year. The Justice and Development Party won victories in general elections of 2002, 2007 and 2011, as well as in local elections in 2004 and 2009.

Another offshoot of the Islamic Felicity Party was formed by Numan Kurtulmus and his supporters, under the name of People's Voice Party (HAS Parti) in 2010. This party participated in the 2011 general elections, but subsequently merged with the Justice and Development Party in September 2012. 


\section{The Headscarf Debate}

Even though the first official nation-wide headscarf ban for public sector workers went into effect on December 8, 1978 in Turkey, the use of head cover has been prohibited in practice since the early 1920 s. ${ }^{50}{ }^{51}$ While the enforcement of the headscarf ban among government employees has not been extensively debated, the application of the ban in schools has been a center of contention. The headscarf ban in schools goes back to the first constitution of the Republic of Turkey, which was adopted in 1924. For primary school students (i.e., the first 5 years of schooling), the headscarf ban has always been strictly enforced. However, the extent of enforcement in secondary and tertiary schools varied over time. In non-vocational secondary schools (i.e., middle schools and high schools with no vocational training), students have not been allowed to wear headscarf within the school boundaries. However, in a particular type vocational secondary schools, the religious imam-hatip schools, students could wear a headscarf even though the law explicitly banned the use of headscarf in all school and public workplaces (Cakir et al. 2004). ${ }^{52}$ Headscarf use in universities has been subject to extensive public debate and there have been relatively frequent regulatory changes and variations in the strictness of the enforcement of the headscarf ban since the early 1980s. ${ }^{53}$ While the Council of Higher Education ${ }^{54}$ banned the use of headscarf in universities in 1982, it reversed the decision in 1984. In 1987, the Turkish Parliament

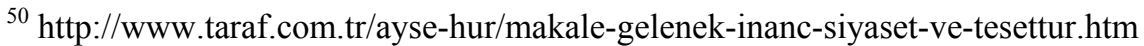

${ }^{51}$ December 8 1978, circular note \#52

${ }^{52}$ Other types of vocational schools include industrial-occupation high schools, girl-occupation high schools, health-occupation high schools, and trade-occupation high schools.

${ }^{53} \mathrm{http}$ ://arama.hurriyet.com.tr/arsivnews.aspx?id=8201449

${ }^{54}$ Yuksek Ogretim Kurumu
} 
passed a law enabling students wearing headscarf to attend universities. The Constitutional Court of Turkey, however, declared the law unconstitutional in 1988. The Constitutional Court of Turkey found a similar legislation unconstitutional in 1990. The Council of Higher Education declared in 1997 that those who wear headscarf shall not be allowed to enter (or attend classes in) universities. The head scarf ban is officially eliminated in October 2013 by the governing Justice and Development Party. ${ }^{55}$

\footnotetext{
${ }^{55} \mathrm{http}: / /$ online.wsj.com/article/SB10001424052702303442004579123320877810350.html http://www.nytimes.com/2013/10/09/world/europe/turkey-lifts-ban-on-head-scarves-in-stateoffices.html? $\mathrm{r}=0$ http://news.nationalgeographic.com/news/2013/10/131011-hijab-ban-turkey-islamic-headscarf-ataturk/
} 


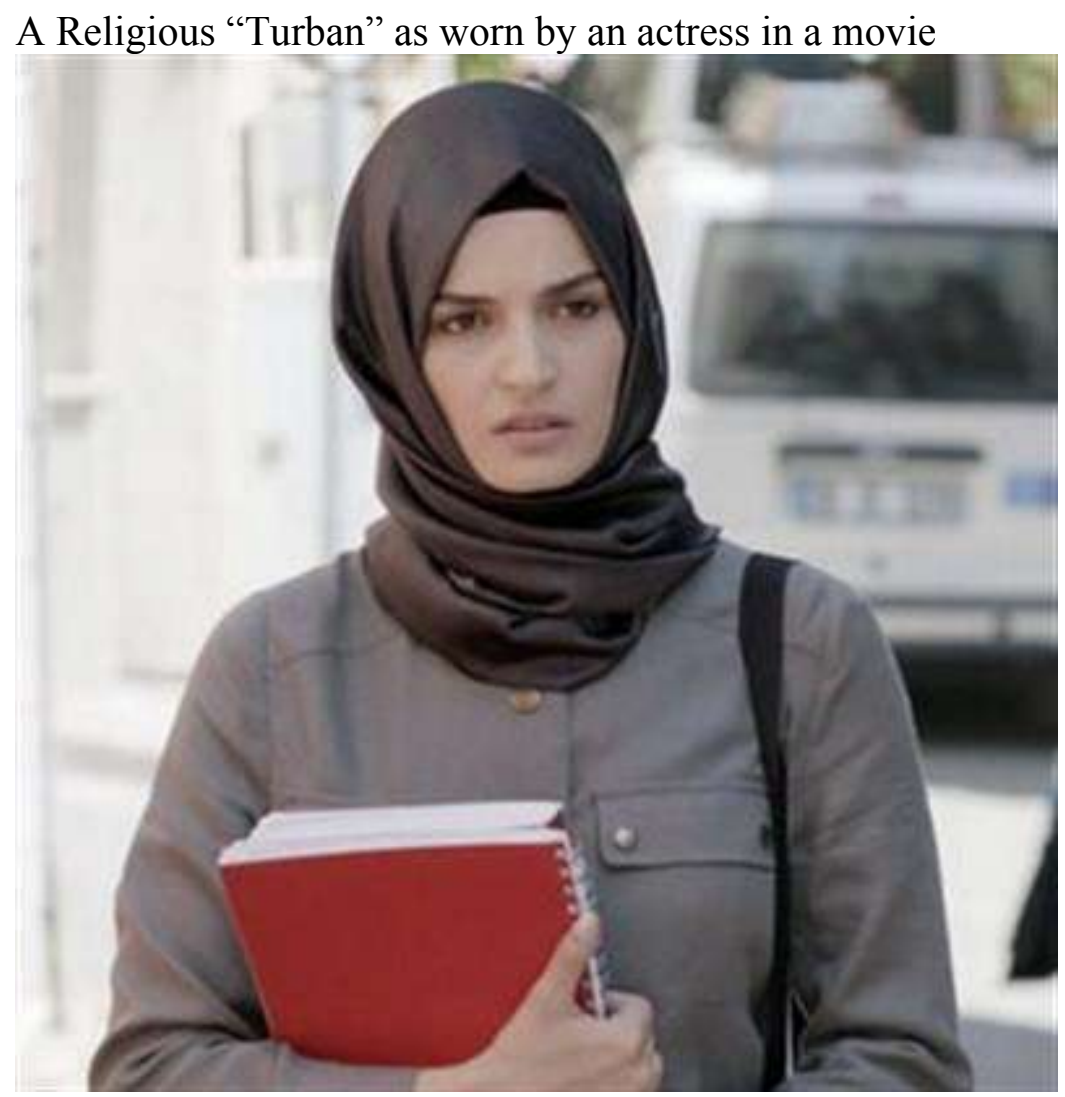

Photo credit: http://kadinvemadam.blogspot.com/2013/05/selin-demiratar-da-tesetturegirdi.html. May, 2013. 